\title{
Assessing the landscape visual quality of Shar Planina, North Macedonia
}

Daniela Jovanovska (Corresponding author)

Geography, Staffordshire University, College Road, Stoke-on-Trent, Staffordshire, ST4 2DE, UK

Faculty of Natural Sciences and Mathematics, Ss. Cyril and Methodius University of Skopje, Arhimedova No. 3, 1000 Skopje, Republic of North Macedonia

Tel: $+44(0) 1782294104$

Email: daniela.jovanovska@research.staffs.ac.uk

https://orcid.org/0000-0001-9344-5970

Ruth D. Swetnam

Geography, Staffordshire University, College Road, Stoke-on-Trent, Staffordshire, ST4 2DE, UK

https://orcid.org/0000-0002-5199-9622

Fiona S. Tweed

Geography, Staffordshire University, College Road, Stoke-on-Trent, Staffordshire, ST4 2DE, UK

https://orcid.org/0000-0002-4299-6788

Ljupcho Melovski

Faculty of Natural Sciences and Mathematics, Ss. Cyril and Methodius University of Skopje, Arhimedova No. 3, 1000 Skopje, Republic of North Macedonia

https://orcid.org/0000-0001-7632-9310 


\section{ABSTRACT}

\section{Context}

Landscape quality assessment provides a contextual basis for integrating cultural ecosystem services within landscape management and policy. However, measuring landscape visual quality remains a challenge; especially in the Balkans with its complex environmental and socio-cultural history.

\section{Objectives}

In response, we present a first assessment of landscape visual quality across Shar Planina, North Macedonia and test the transferability of a visual quality assessment method (VQI) originally developed to evaluate Northwest European landscapes.

\section{Methods}

This study includes remote (GIS) and field assessment. The latter produced quality measures which were summarized, scaled and weighted into an index $(0-1.0)$ and served as a ground-truth dataset for subsequent GIS assessment. To assess how spatial scale affects the VQI and what scale is most appropriate to capture perceived landscape quality, the remote assessment was applied at scales ranging from 1 to $5 \mathrm{~km}^{2}$ and results were then correlated to field assessment results.

\section{Results}

Values for the field VQI range from 0.2 to 0.82 whilst the values from the remote assessment applied at 1 $\mathrm{km}^{2}$ range from 0.1 to 0.74 and increase to $0.77,0.84$ and 0.86 at $2 \mathrm{~km}^{2}, 3 \mathrm{~km}^{2}$ and $5 \mathrm{~km}^{2}$ respectively. Strongest correlation between the GIS and the field assessment was observed at $2 \mathrm{~km}^{2}$, which captured detail whilst remaining appropriate to the perceived landscape.

\section{Conclusions}

Our research allows consideration of this cultural ecosystem service within the wider conservation efforts on Shar Planina and provides methodological guidelines for assessments of visual quality of mountainous landscapes elsewhere in the region.

Keywords: landscape appeal, landscape aesthetics, landscape assessment, GIS, landscape management 


\section{INTRODUCTION}

The long-term interaction between humans and nature has nurtured the scenery of our surroundings. Over time the intensity and magnitude of human-induced change has increased dramatically (Lambin et al. 2001; Turner et al. 2007; Jepsen et al. 2015). This affects the functionality and appearance of our valued landscapes (Meeus et al. 1990; Falcucci et al. 2006; Hunziker et al. 2008; De Pablo et al. 2012). The urgent matter of landscape change has been highlighted by European conservation policies (Council of Europe 1996; Council of Europe 2000) that provide a framework for integrated intergovernmental efforts towards the preservation of landscape character and its quality. The subsequent ecosystem service framework (Hassan et al. 2005; see also Díaz et al. 2015; Díaz et al. 2018) has drawn further attention to the importance of landscape visual quality by recognising landscape aesthetics as an important cultural ecosystem service.

Landscape visual quality mirrors landscape change and its environmental impacts (Gulinck et al. 2001; Gobster et al. 2007) and drives the delivery of a bundle of other cultural ecosystem services that engage people with nature, such as enjoyment of nature, inspiration, recreation and sense of place (Tengberg et al. 2012; Plieninger et al. 2013). The importance of landscape scenery has been further emphasised with regards to its potential to serve as a communication tool to increase support for nature conservation (Gobster et al. 2007) and inform landscape management and policy (Tratalos et al. 2016).

Given the importance of landscape as a construct of nature with which people can identify, the visual characteristics of landscape and its quality have been studied for some time. How much we like or dislike a certain landscape depends on both its biophysical features and the perceptual response that those features evoke in the human observer; hence there is still a lack of consensus regarding the most suitable approach to calculate landscape visual quality (Lothian 1999; Daniel 2001; Dakin 2003; Price 2013). Though preferences vary, accumulated studies on interactions between landscape physical attributes and their perception (e.g. Arriaza et al. 2004; Garré et al. 2009; García-Llorente et al. 2012; Pecher et al. 2018) agree on a common set of landscape elements that evoke positive or negative responses (Dramstad et al. 2006). Also, recent extensive reviews of existing conceptual approaches (Tveit et al. 2006; Ode et al. 2008; Fry et al. 2009) have established a link between landscape aesthetic theory and visual indicators and have provided a common platform for exploring the contribution of composition and arrangement of landscape elements in landscape preference. Boosted by the technological advances in Geographic Information Systems (GIS) and increased availability of digital datasets, studies have built on existing foundations to produce large-scale predictive models of landscape visual quality. Such 
assessments (Otero Pastor et al. 2007; Uzun and Muuml 2011; Vizzari 2011; Ramos and Pastor 2012; Swetnam et al. 2017) provide background for subsequent perceptual studies and allow consideration of landscape aesthetics within landscape policy, management and planning (Dramstad et al. 2006; Daniel et al. 2012).

While studies with reference to visual quality of agricultural (Howley et al. 2012; Rechtman 2013) and rural landscapes (Arriaza et al. 2004; Rogge et al. 2007; Howley 2011; García-Llorente et al. 2012; Swetnam et al. 2017) are relatively abundant in Northwest Europe, little attention has been given to Southeast European landscapes. Featuring highly varied natural environments and complex socio-cultural and land-use history, Southeast Europe accounts for a significant portion of landscape diversity in Europe (Mücher et al. 2010; Perko and Ciglič 2015) characterised by high visual quality (Ramos and Pastor 2012). Counterbalancing these values, the increasing endeavours of developing Balkan countries to compete with the developed countries of Northern and Western Europe threatens the ecological, aesthetic and cultural-historical values of unique Balkan landscapes. In a developing country like North Macedonia, the pace of change is rapid and its effects are visible within a short timeframe. Continuity in socio-political and economic struggles have influenced the pattern and specifics of land-use (Despodovska et al. 2012; Jovanovska and Melovski 2012) and altered the specifics of landscape appearance. This is especially notable in mountainous landscapes that straddle borders and are of high conservational importance.

Although mountain ranges are associated with high landscape quality (Ramos and Pastor 2012; Perko and Ciglič 2015), studies that focus on landscape visual quality in mountainous regions are rare, even in developed Europe (Grêt-Regamey et al. 2007; Otero Pastor et al. 2007; Vizzari 2011; Schirpke et al. 2013). To date, there have been no trials in transferring landscape visual quality assessment methods to accommodate the specifics of Southeast European landscapes. In return, these understudied landscapes still lack a baseline from which to monitor and manage the impact of change on their scenic quality. In reality, despite the apparent need to review the applicability and reproducibility of existing visual quality assessment methods, very few studies have attempted to transfer assessment methods between landscapes in environmental and socio-cultural different regions (notable exceptions include: Schirpke et al. 2013; Swetnam and Tweed 2018).

To address this research gap, this study tests the transferability of the GIS-enabled method for landscape visual quality assessment originally developed for rural Wales (Swetnam et al. 2017), successfully piloted in Iceland (Swetnam and Tweed 2018) and investigates its applicability to the very diverse landscapes of Shar Planina (Melovski et al. 2019), a mountainous region in North Macedonia. 
Overall, this study aims to assess the landscape visual quality of the Shar Planina mountain range and provide a detailed baseline from which the effects of landscape change on this important cultural ecosystem service can be monitored and managed. To achieve this we had five specific objectives: (i) adapt an existing visual quality assessment tool, the Visual Quality Index (VQI) originally developed for use in rural Wales (Swetnam et al. 2017) and Iceland (Swetnam and Tweed 2018) to include both quantitative and qualitative approaches to visual quality assessment (ii) apply the visual quality assessment on the overall extent of Shar Planina by applying remote (GIS) and field-based approach to its calculation (iii) determine if the VQI recorded as part of the remote visual quality assessment corresponds to that of field visual quality assessment (iv) likewise, determine if the VQI recorded within the quantitative component of the field visual quality assessment reflects the landscape appeal provided within its qualitative/perceptual component ( $v$ ) explore the methodological considerations in transferring the visual assessment tool whilst addressing the effect of spatial scale to determine which is most appropriate to capture perceived landscape quality.

\section{METHODOLOGY}

\section{Study area}

The Shar Planina mountains are part of the Dinaric range and straddle the border between northwest North Macedonia and southwest Kosovo (Figure 1). With an area of $830 \mathrm{~km}^{2}$ and its main crest stretching up to $80 \mathrm{~km}$ in length, Shar Planina is one of the largest mountain ranges in North Macedonia (Melovski et al. 2013). The mountain range has many peaks over $2500 \mathrm{~m}$ in elevation, the highest being Titov Vrv $2748 \mathrm{~m}$ a.s.I. Geologically, the mountain range is mostly characterised by silicate rocks that give way to limestone above 1000 m a.s.l. (Melovski et al. 2010). The climate of Shar Planina is Continental to Mountainous and somewhat modified by the influence of the Sub-Mediterranean climate (Lazarevski 1993). Shar Planina massif is known for its dense river network and the presence of 39 glacial lakes in total, 27 of which are in North Macedonia (19 permanent and 8 temporary). These specifics of Shar Planina result in an outstanding diversity of habitats and an exceptionally rich diversity of species (Melovski et al. 2010). 

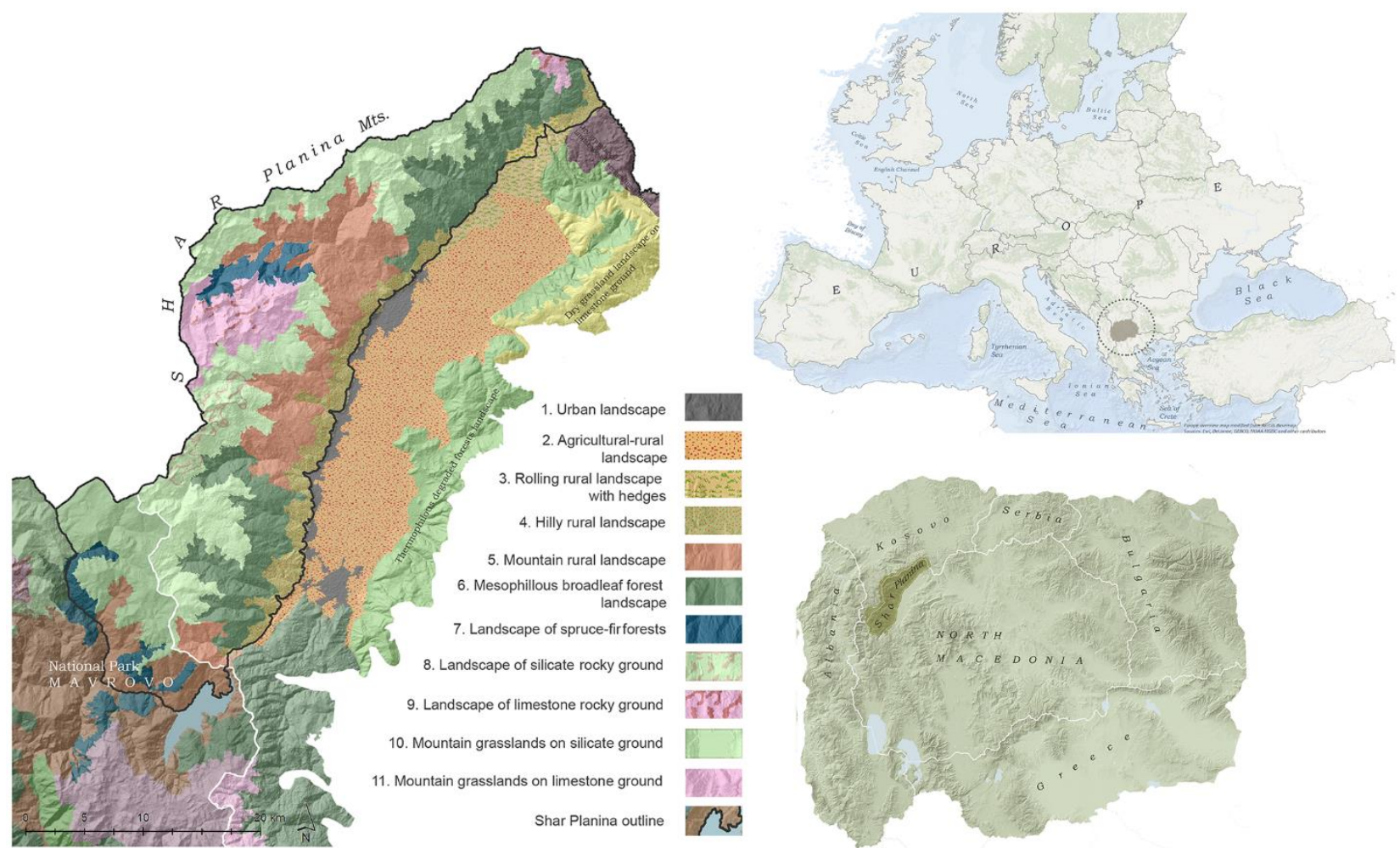

Fig. 1. Geographical position of the study area including representation of landscape diversity in accordance with Melovski et al. (2019).

Administratively the mountain range belongs to 7 municipalities (State Statistical Office of the Republic of Macedonia 2012) encompassing about 80 settlements and 2 cities: Tetovo (total population of 52 915) and Gostivar (total population of 35 847). The foothills of Shar Planina are densely populated (total population in settlements ranging from 311 to 8353 , averaging $\approx 3000$ ) whilst the higher slopes are characterised by presence of rural settlements that span up to $1500 \mathrm{~m}$ a.s.l., somewhat clumped in character, but disjointed and sparsely populated at most (total population ranging from 0 (in abandoned villages that are mostly occupied in summer time) to 2826 (fewer than 10 villages have population higher than 1000), averaging $\approx 500$ ) (State Statistical Office of the Republic of Macedonia 2002). The diverse traditional, ethnic and cultural background of its inhabitants and their accustomed practices has left a specific imprint on natural ecosystems of Shar Planina and led to the formation of a specific landscape mosaic (Melovski et al. 2019).

The landscapes of Shar Planina can be categorised into 9 types (Melovski et al. 2019); these are rural landscapes (rolling rural landscape with hedgerows, hilly rural landscape, mountain rural landscape), forest landscapes (mesophillous broadleaf forest landscape, spruce-fir forest landscape), mountain grassland landscapes (mountain grassland landscape on silicate ground, mountain grassland landscape on 
limestone ground) and mountain rocky landscapes (landscape of silicate rocky ground and landscape of limestone rocky ground) (Figure 1). Two other landscape types spread in the foothills of the mountain and intersect with the study area: these are the flatland sub-continental agricultural-rural landscape of mixed cultivation pattern (Polog landscape) and the urban landscape (Melovski et al. 2019).

The existing landscape mosaic (Figure 1) is affected by the rapid shift of political and environmentalsocietal processes, hindered policy implementation and intensified aspirations for development. Some of the major threats affecting landscape diversity on Shar Planina are abandonment of traditional land-use practices, migration and emigration, land conversion, excessive use of natural resources and climate change (Melovski et al. 2010).

In order to respond to these threats and with consideration of both the biological and landscape diversity hosted by Shar Planina, there is a longstanding intention to establish a protected area over the full extent of this mountain range. The future National Park, a merger to Mavrovo National Park, is meant to complement the continuum of the protected areas in the neighbouring states of Kosovo and Albania, thus creating one of the largest transboundary protected areas in Europe.

\section{Visual quality assessment}

To assess the visual quality of Shar Planina, this study adapts an existing method - the Visual Quality Index (VQI) (Swetnam et al. 2017). The VQI measures landscape visual quality as a weighted sum of five contributing themes: Physical, Blue space, Green space, Human and Historic and was originally developed to address the specifics of Welsh rural landscapes.

The original Welsh visual quality assessment (Swetnam et al. 2017) was designed as a GIS-enabled method to provide a detailed baseline for monitoring changes in landscape visual quality for a representative sample of Welsh landscapes. Relying on a high-quality digital database and a heavy emphasis on desk-based quantitative methods, including fine-scaled habitat survey data, the application of the VQI in Wales was restricted to $1501 \mathrm{~km}^{2}$ sites. However, a significant portion of the parameters that make up the VQI could be calculated using freely available datasets. In this regard, careful choice of location-specific parameters and evaluation of appropriate weightings raises the potential for transferability of the visual quality assessment method to other data-scarce locations. Its successful adaptation in Iceland (Swetnam and Tweed 2018) was a field application of the VQI that primarily aimed to complement the quantitative (biophysical) component of the VQI by integrating qualitative/perceptual approaches (appeal) to its application. As such, the visual quality assessment applied in Iceland was 
focused on a selection of 32 landscape views assessed by four assessors and does not include a GIS assessment. However, the study provides recommendations to implement these field-tested parameters within a GIS whilst also raising the question of potential effects of scale on the output of the VQI in terms of tractability for processing and its capacity to capture the scale of the landscape; particularly with reference to landscapes that are characterised by open extended views, such as Iceland. Furthermore, the study tackles the potential transferability and the portability of visual landscape quality metrics between different landscape settings by identifying common core metrics related to built environment and transport, topography and water features.

This study includes both remote (GIS) and field assessments, with the latter including elements of quantitative/biophysical and qualitative/perceptual approaches to landscape assessment. Recognising the importance of landscapes as an effective framework for addressing and managing the effects of change (Turner et al. 2007) the visual quality assessment was tailored to address the full range of landscape types of Shar Planina (Melovski et al. 2019) throughout its full extent within country borders.

\section{Adapting the VQI to Shar Planina}

To assess the landscape visual quality of Shar Planina, we have adapted the metrics used within the Welsh and the Icelandic visual quality assessments to reflect the landscape characteristics of the mountain range, as summarised in Table 1. Detailed metrics overview for both field-based and remote (GIS) visual quality assessments, including applied alterations and calculation specifics, are provided in Table S1 and Table S2 in the supplementary material.

The VQI for Shar Planina was developed with consideration of each of the five themes that were elaborated in detail in Swetnam et al. (2017) and revisited in Swetnam and Tweed (2018) and thus here we only provide a general outline with relevance to the study site.

The Physical theme considers the topographical diversity of the landscape and contributes positively to the overall VQI. The physical theme was originally a measure of terrain ruggedness (Swetnam et al. 2017), whilst in the case of Iceland (Swetnam and Tweed 2018) it included geological phenomena as an additional metric. Increase in ruggedness of the terrain captures variations in topography and is commonly associated with high visual quality within both physical (Otero Pastor et al. 2007; Uzun and Muuml 2011; Vizzari 2011) and perceptual studies (Arriaza et al. 2004; Acar et al. 2006; Schirpke et al. 2013). 
Table 1. Metrics applied in the quantitative component of the field visual quality assessment of Shar Planina (Q1 to Q26) including measures of its qualitative component i.e. personal landscape appeal and ephemeral aspects.

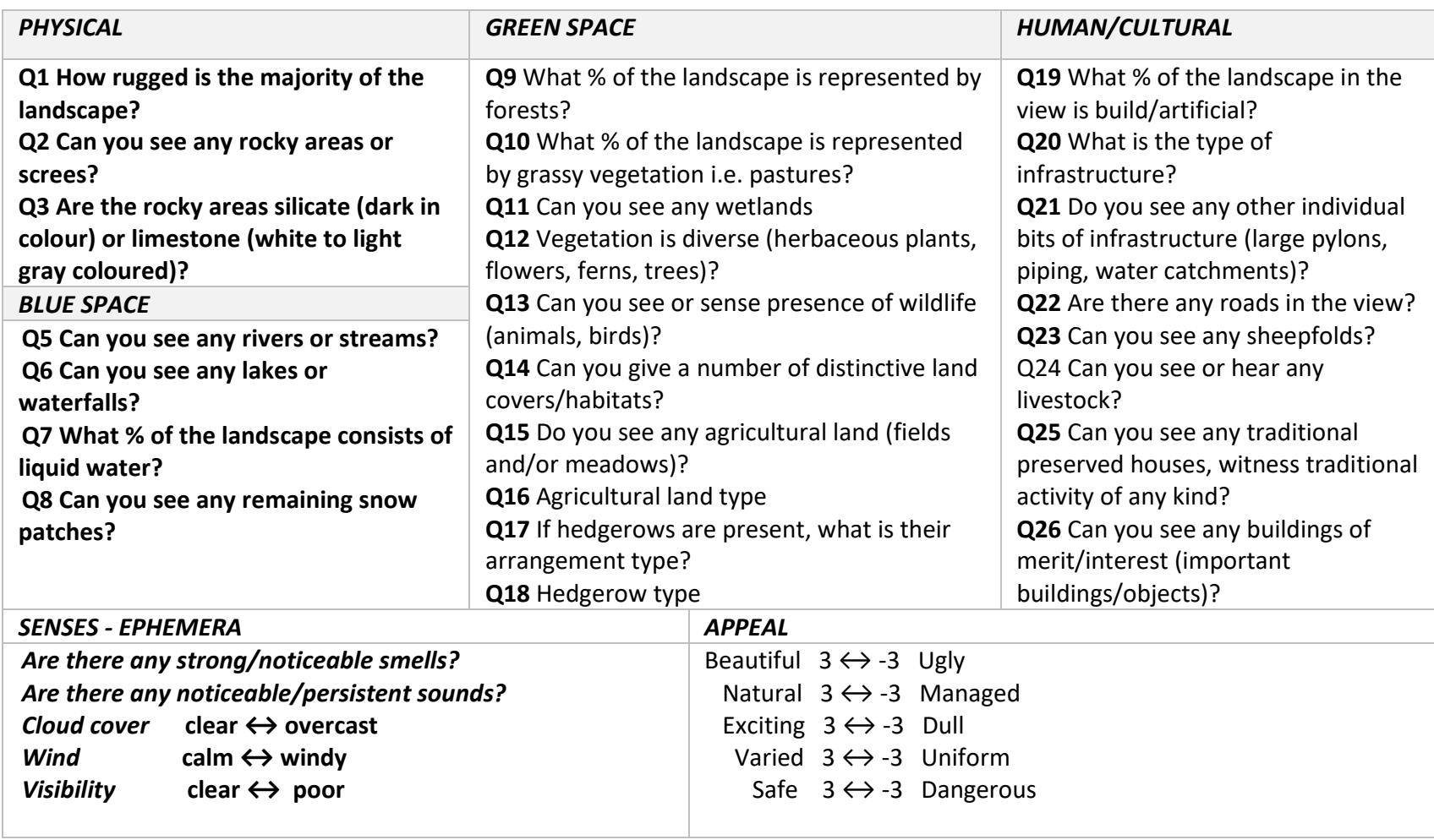

Due to its high elevation range, Shar Planina has high topographical diversity that is captured by seven types of terrain ruggedness. Rocks and rocky areas add to the textural complexity to the terrain and thus contribute to a higher visual quality rating (Sari and Acar 2016); this is especially relevant for mountainous areas where massive rocks alternate with terrain ruggedness. Because rocky areas and screes are a specific attribute for many of Shar Planina's highest peaks, we added this as an additional metric within the physical theme. The type of rocks, whether silicate or limestone, has also been considered since colour affects the physical perception of composition (Howley 2011; Sari and Acar 2016).

The Blue space theme considers the presence of water (rivers, lakes, waterfalls, springs) and ratings increase proportionally with increasing presence of water features and areas under water. The presence of water features is consistently associated with high landscape appeal (e.g. Arriaza et al. 2004; Dramstad et al. 2006; Acar et al. 2006; Bulut and Karahan 2010; Schirpke et al. 2013). In the case of Wales and Iceland, this theme is captured by assessing the presence and scale of water features like rivers, waterfalls, lakes, ponds etc. and both include presence of coast. In the context of Iceland it includes two 
additional metrics related to frozen water (snow, glaciers) while also considering their appearance (colour).

Shar Planina is characterised by rich hydrography in terms of both the amount of water and the diversity of water features. Narrow riverbeds of rivers and streams alternate with steep terrain and contribute to the formation of numerous rapids, cascades and small waterfalls. Standing water is mostly represented by a large number of temporary or perennial glacial lakes and ponds. Other specifics of Shar Planina are the numerous small snow patches, remnants of the thick winter snow cover that give a distinctive colour pattern to this mountain range, most notable in spring. With consideration of site characteristics, this study combines the metrics used for Wales and Iceland and considers the presence of rivers, lakes, waterfalls, springs and presence of snow.

The Green Space theme relates to naturalness and vegetation diversity in the view, both consistently associated with high visual quality throughout physical (e.g. Gobster et al. 2007; Otero Pastor et al. 2007; Ferrari et al. 2008; Uzun and Muuml 2011) and perceptual studies (e.g. Purcell and Lamb 1998; Acar et al. 2006; Rogge et al. 2007; Ode et al. 2009; van der Jagt et al. 2014). In case of Wales, the Green space theme measures habitat richness and plant diversity, area of woodland, presence of single large trees and length of hedgerows. In Iceland, the Green space theme is captured by measuring vegetated area and the presence of flowering plants in the view, whilst also including presence of livestock and birds.

Shar Planina is characterised by high diversity of flora and fauna. Vegetation is distributed zonally starting with forests at lower altitude, followed by pastures, heaths, rocks and rocky ground that occupies the highest altitudes. The deciduous forests range zonally from thermophilous oak forests to montane and subalpine beech forests at a higher altitude, where there are also large areas covered with coniferous and mixed forests. Subalpine (secondary) mountain grasslands and alpine grasslands cover a significant part of Shar Planina (Melovski et al. 2010). A significant portion of the natural ecosystems of Shar Planina has been re-shaped throughout the long history of accustomed agricultural land management practices. The specifics of the appearance of the resulting mosaic of agricultural and rural landscapes are varied and are reflected in the appearance, composition and arrangement of fields and hedges. With consideration of site specifics, this study combines the metrics used in the Welsh and the Icelandic study while also considering the type of agriculture and hedgerow type and arrangement on Shar Planina. Livestock breeding is considered within the cultural theme. Instead, within the Green Space theme we consider the presence of all wildlife, as wildlife encounters are common. This study further extends the metrics of the Green space theme by considering the presence of wetlands. Wetlands on Shar Planina have low visibility 
of water surface or water surface is absent and so their positive contribution to landscape appeal is considered within the Green Space theme. Wetlands provide visual contrast and diversity to the larger landscape (Ode et al. 2010; Ode and Miller 2011) and are further associated with high vegetation diversity (Dramstad et al. 2006) and common presence of birds, amphibians and invertebrates (AriasGarcía et al. 2016).

The Human theme relates to the concept of disturbance (Ode et al. 2008; Fry et al. 2009) and measures the presence and dominance of constructed/artificial habitats and infrastructure that are generally assessed to have a negative impact on landscape quality within both physical (Gulinck et al. 2001; e.g. Otero Pastor et al. 2007; Uzun and Muuml 2011) and perceptual studies (Kaplan et al. 2006; Acar et al. 2006; Garré et al. 2009; Howley 2011; van der Jagt et al. 2014). In the case of Wales, this theme calculates the area of built and human influenced habitats, presence of linear infrastructure like utilities and roads and rates negatively within the final VQI.

In contrast, the Historic/Cultural theme rates positively and captures the presence of historical and cultural features within the landscape that link to the concepts of stewardship, historicity and imageability (Ode et al. 2008; Fry et al. 2009) and are commonly associated with high landscape preferences (e.g. Arriaza et al. 2004; Rogge et al. 2007). The Historic/Cultural theme within the Welsh VQI considers the presence of stone walls, ancient monuments, listed buildings and historic parks. Due to scarcity of cultural and historic elements within the wider Icelandic landscape, the Human and the Historic/Cultural theme are considered within one theme Built/Historic that measures the presence of buildings and linear infrastructure, including presence and type of roads and presence of buildings of historic or cultural importance.

Considering the study area specifics and bearing in mind that joint consideration of both Human and Historic/Cultural themes within one theme did not have an adverse effect to the final outputs of the VQI, this study follows the Icelandic VQI assessment and considers both Human and Historic/Cultural themes within one theme: Human/Cultural. Due to its environmental constraints and its high elevation gradient, Shar Planina is characterised by uneven presence and arrangement of both human and cultural features. Presence of constructed/artificial habitats is most notable in the foothills of the mountain and generally declines in both presence and intensity with increase in altitude (going from urban to agricultural and then rural landscapes). Cultural features are mostly clustered in the vicinity of settlements and are usually represented by religious objects (churches, monasteries, mosques), fountains and individual monuments. 
In the high mountain belt, human structures are sparse and usually represented by sheepfolds that are considered to have a high cultural importance, as sheep breeding is a traditional activity that has been practiced for many centuries. Other objects of cultural/and or historical importance found across the natural landscape include mountain huts, sheds, shelters and small cottages. Within the Human/Cultural theme in the VQI assessment of Shar Planina, the area of built and human influenced habitats, presence of linear infrastructure (utilities) and presence of roads (with consideration of type of roads) are considered to have a negative contribution to the overall VQI. Presence of important buildings, presence of traditionally preserved houses (including witnessing of traditional activities e.g. shepherding, ploughing, mowing etc.) and presence of sheepfolds or sighting of livestock are considered to have a positive contribution to the overall VQI.

\section{Field visual quality assessment}

The draft VQI assessment tailored to Shar Planina was field-tested as a pilot study and the content was then further revised to reflect the specific landscape components of the mountain range. Following final revisions, the field visual quality assessment (Table 1) was applied to sites distributed along accessible hiking trails selected to cover the full extent of the mountain range, resulting in 179 sites being assessed. Site selection was done at random, intended to capture the diversity of views along selected routes and to secure full representation of the variety of landscape types. To address the ease of application and the potential influence of individual perceptions of assessors on the implementation of the VQI (for example, variations in assigned ratings within the quantitative component of the field visual quality assessment and variations in appeal responses within its qualitative component), 35 sites were assessed by two or more assessors with the mean number of assessments per site being three and the mean number of replicates by different assessors being seven. Fifteen assessors volunteered to take part in the study, all with a background in environmental sciences; some were new to the region while most have visited the region more than few times. To ensure consistency in assessments, all assessors took part in a one-day training course aimed to familiarise the participants with the concept of visual quality assessment and provide participants with practice in assessing the VQI on 10 trial sites. To ensure consistency between assessors working independently, field visual quality assessment was carried using a digital form provided in Memento, a synchronised database application. Overall, the field visual quality assessment resulted in 233 field-site entries.

Field visual quality assessment served as a ground-truth dataset for the remote (GIS) visual quality assessment. The final output from the field visual quality assessment has been interpolated with 
consideration of topographical constraints on the viewshed to complement the remote visual quality assessment (see Results).

\section{Remote (GIS) visual quality assessment}

GIS visual quality assessment corresponds to the metrics applied within the field visual quality assessment (Table 1) with consideration of available digital data as a constraint (especially with regards to field observations of traditional activities, livestock, wildlife etc.). The GIS VQI was interpreted from available remotely sensed data sources (Sentinel-2 and Google Earth satellite imagery and ASTER GDEM) and vector data. Due to absence of readily available digital data, most of the vector data required for the remote VQI assessment were derived by digitising information presented on 1:25000 topography maps (Agency for Real Estate Cadastre of the Republic of Macedonia) with consideration of Google Earth satellite imagery. Though Corine Land Cover (EEA 2018) is widely used throughout environmental and visual quality assessment studies, its strength is primarily its use in coarse scale analyses over large extent with revisions available every 6 years. Considering the scale and extent of the study area and with further consideration of specifics of VQI assessment metrics that relate to land cover types, we used a customised land cover classification for Shar Planina (Jovanovska 2019). The customised land cover classification was developed from Sentinel-2 (ESA) multiband high resolution images and includes 12 land cover classes: rocky areas and screes, pastures, lakes, spruce-fir forests, beech forests, mixed thermophilous forests, transitional scrubland, dry grasslands, heterogeneous agriculture - fields and meadows, agricultural land - cropland, populated areas and mineral extraction sites. Computer processing was performed with ArcGIS 10.6.

Metrics applied within the GIS visual quality assessment are presented in Figure 2. Detailed overview of the GIS visual quality assessment including assessment specifics and applied alterations are provided in Table $\mathrm{S} 2$ in the supplementary material. 


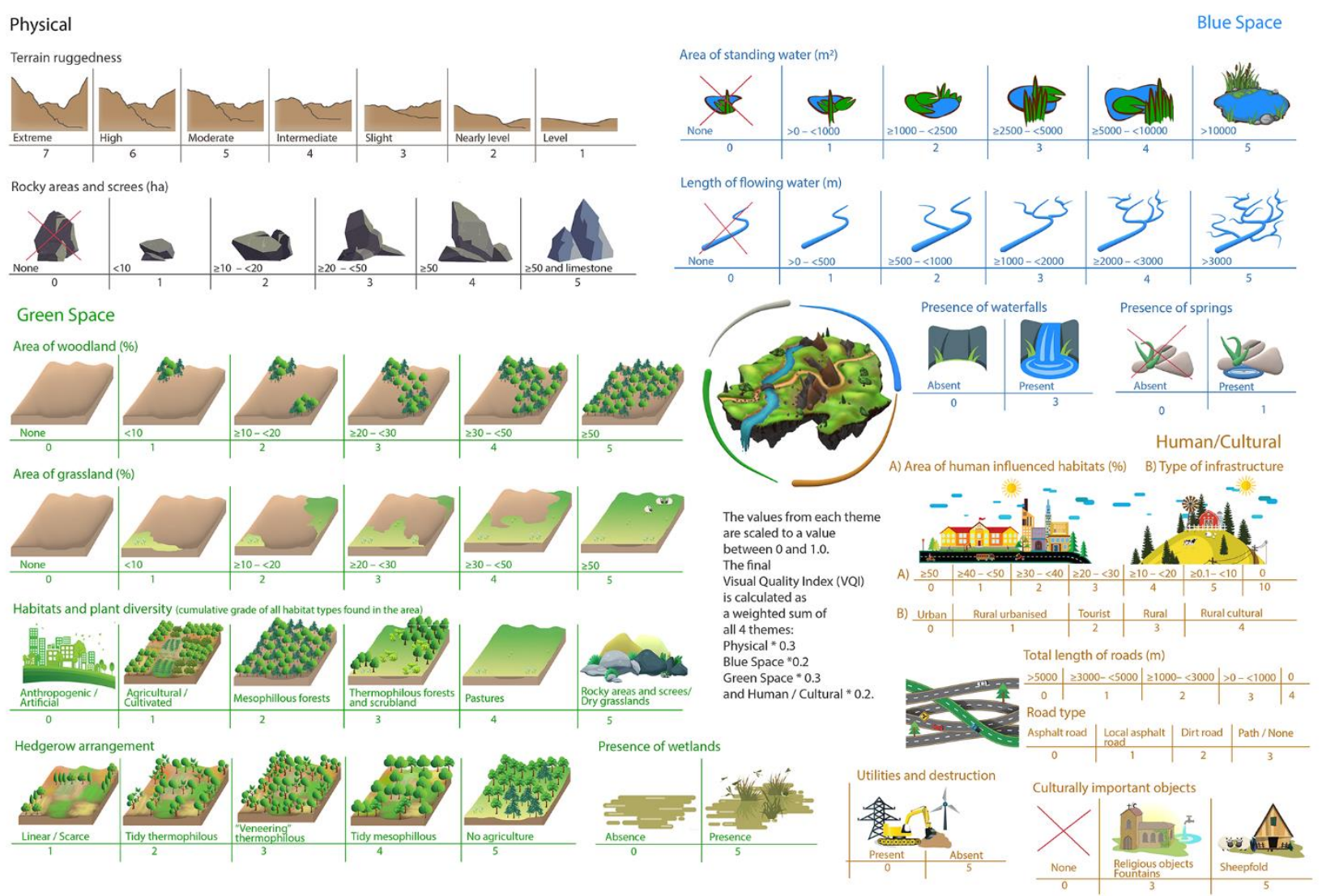

Fig. 2. Graphical representation of the methodological approach used in remote (GIS) visual quality assessment of Shar Planina landscapes

The GIS visual quality assessment calculates the VQI index for a total of $11601 \mathrm{~km}^{2}$ survey sites. All sites have been marked with a unique code containing the principal latitude and longitude information for the site. To address continuity in the view, the extent of the remote VQI assessment exceeds the outline of Shar Planina (Melovski et al. 2013) to include its immediate surrounding. The $1 \mathrm{~km}^{2}$ scale was taken to provide fine-scale reference to the field visual quality assessment and provide a detailed representation of the visual quality results.

In order to provide insight into the shift of VQI values across range of scales and determine what spatial scale is most to appropriate to capture perceived landscape quality (Swetnam and Tweed 2018) this study tests the application of the remote VQI within site squares of varying size. Due to its high elevation range, Shar Planina delivers long panoramic views and under clear sky conditions (that are common in the region) provides medium distance line of sight views that extend from 5 to $20 \mathrm{~km}$ in range.

Furthermore, the openness of the high-mountain landscapes that straddle the forest line increases the 
visual perception of both diversity and complexity of its relief. Considering the limitations of the $1 \mathrm{~km}^{2}$ scale with reference to the surrounding setting and the openness and extensiveness of the view, the analysis was repeated at $2 \mathrm{~km}^{2}, 3 \mathrm{~km}^{2}$ and $5 \mathrm{~km}^{2}$ scales.

Another approach to capturing the visual quality in mountainous areas like Shar Planina is to consider the full range of extent in views by using a detailed viewshed (Swetnam et al. 2017). However, this approach would be time-consuming and require detailed consideration of viewpoints, consideration of lines of sight and would present limitations in terms of data availability, viewshed overlay, ability to capture the appeal of closed views, differences in scaling metrics within range of extents etc.

\section{Calculating the VQI}

Within its quantitative/biophysical assessment, the final VQI score is calculated as a weighted sum of four contributing themes: Physical, Blue space, Green Space and Human/Cultural (Swetnam et al. 2017; Swetnam and Tweed 2018). The values from each theme are first scaled to a value between 0 and 1.0, and then the four thematic values are weighted in their contribution to the final index. The impact of changing weights between themes was evaluated by conducting a sensitivity analysis, which demonstrated that when all four themes are considered, the VQI remains stable when individual theme weights remain in the range between 0.1 and 0.4 (see Swetnam et al. 2017).

Within its qualitative/perceptual assessment the overall appeal is calculated as a sum of separate appeal scores (see Table 1, Table S1) and has a theoretical maximum of +15 (all individual appeal categories are rated as +3 ) and a theoretical minimum of -15 (all individual appeal categories are rated as -3 ).

Considering that landscapes on Shar Planina range from agricultural to rural and highly natural, when calculating the VQI score in field visual quality assessments, we applied different scaling for managed and natural landscapes within the Green space theme. Agricultural and rural landscapes were scaled differently to forest landscapes, mountain grassland landscapes and mountain rocky landscapes. If the question 'Do you see any agricultural land (fields and/or meadows)?' was answered as No (see Table 1, Table S1), then the Green space theme was scaled by 16 (maximum value of theme if agricultural areas were absent) instead of 25 (maximum value of theme if agricultural areas were present). By adjusting the scaling of the Green space theme when calculating the VQI in field visual quality assessments, we avoid a decrease in value of typical natural landscapes views due to absence of elements that are not representative and are not expected to be seen by the observer. In the case of the GIS visual quality assessment this was levelled by applying the highest rating to natural landscapes within GS4 and GS5 (see 
Table S2). Calculation specifics and examples of the impact of weighting of each theme on the final VQI are presented in S3 in the supplementary material.

To determine if the VQI recorded within the quantitative component of the field visual quality assessment reflects landscape appeal provided within its qualitative/perceptual component, correlation analysis was applied to VQI scores and appeal ratings resulting from the field visual quality assessment. Also, resulting VQI scores from both field and remote (GIS) visual quality assessment applied at different spatial scales were correlated to determine if the VQI recorded as part of the GIS visual quality assessment captures the VQI recorded as part of field visual quality assessment. This determined which spatial scale is most appropriate to capture perceived landscape quality. The correlation analysis was carried out in $R$ using Spearman rank correlation.

\section{RESULTS}

\section{Field visual quality assessment}

VQI scores for the field visual quality assessment range from 0.2 to 0.82 with a mean of 0.57 and median of 0.6. The overall appeal scores range from -6 to 15 with a mean of 8 and median of 9 . The quantitative component of the field visual quality assessment is positively correlated with both separate and cumulative appeal ratings recorded within its qualitative/perceptual component, with highest correlation being how exciting $(r=0.73)$ the landscape is perceived to be. The quantitative component of field visual quality assessment also correlates to how beautiful $(r=0.68)$, varied $(r=0.61)$ or how natural $(r=0.59)$ the landscape is perceived to be. The weakest and the only negative correlation is observed in relation to how dangerous (or safe) the landscape view is perceived to be $(r=-0.49)$. The correlation coefficient between the quantitatively assessed VQI and the overall appeal scores is 0.65 , with $p=0$ in all cases. The spread of individual appeal ratings in relation to the VQI ratings is presented in Figure 3. The relation of the quantitatively assessed VQI and the qualitatively assessed overall appeal is given in Figure 4 .

When considering site locations evaluated by more than one assessor, major deviations between assigned VQI scores and appeal ratings are uncommon. However, when absolute matches are considered, there is a low level of agreement with reference to personal responses in overall appeal (30\%) and with reference to assigned VQI scores assessed as part of the quantitative component (23\%). When considering the level of agreement with reference to separate appeal criteria, participants had the highest level of agreement for the criteria beautiful/ugly (61\%), followed by natural/managed (59\%) then both exciting/dull and varied/uniform (55\%), while the lowest level of agreement is observed in the 
criteria safe/dangerous (44\%). Though all assessors had a background in environmental sciences, the low level of absolute agreement (even in case of the quantitative component of the field visual quality assessment) captures the subjectivity and differences in perception of landscape elements, but also differences in personal preferences and the associated appeal. Previous experience in field assessments, rather than familiarity was a more significant determinant of the level of agreement amongst assessors. However, the quantitative aspect of the visual quality assessment is based on defined criteria and with the short training provided, it promotes objective assessment regardless of the background of the assessor. Details of field visual quality assessment examples of landscape views assessed by more than one participant, including overview of resulting VQI scores, are provided in S4 in the supplementary material.

To provide insight into the spatial distribution of VQI scores resulting from the field visual quality assessment, interpolated VQI scores from separate site sampling locations are presented on Figure 5e. 

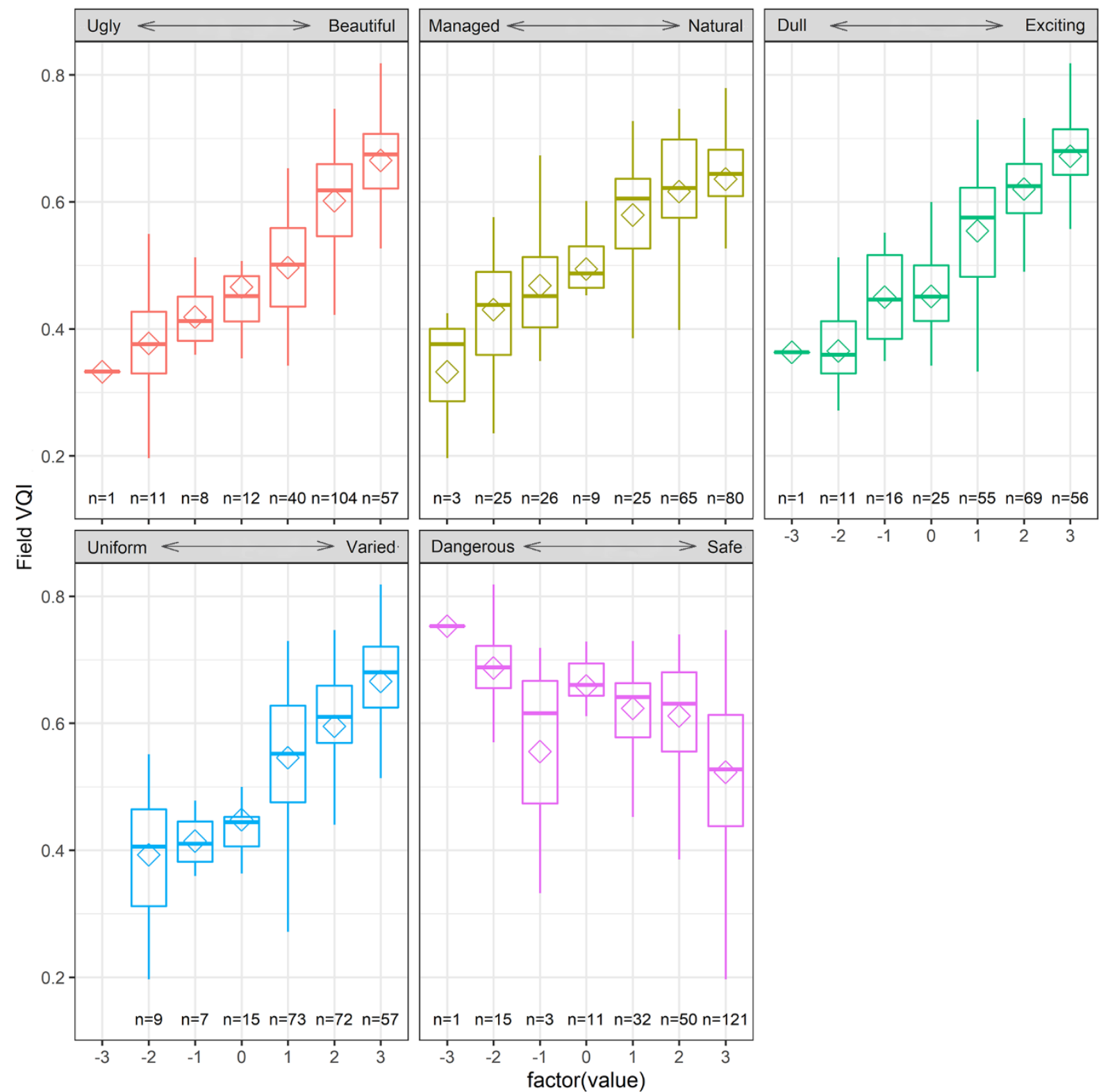

Fig. 3. Overview of separate appeal ratings recorded within the qualitative/perceptual component of field visual quality assessment relative to its quantitative component. VQI ranges from 0 to 1 . Appeal ratings range from -3 (Ugly; Managed; Dull; Uniform; Dangerous) to +3 (Beautiful; Natural; Exciting; Varied; Safe); $\mathrm{n}$ indicates the number of field assessments relative to the corresponding factor (appeal score). 


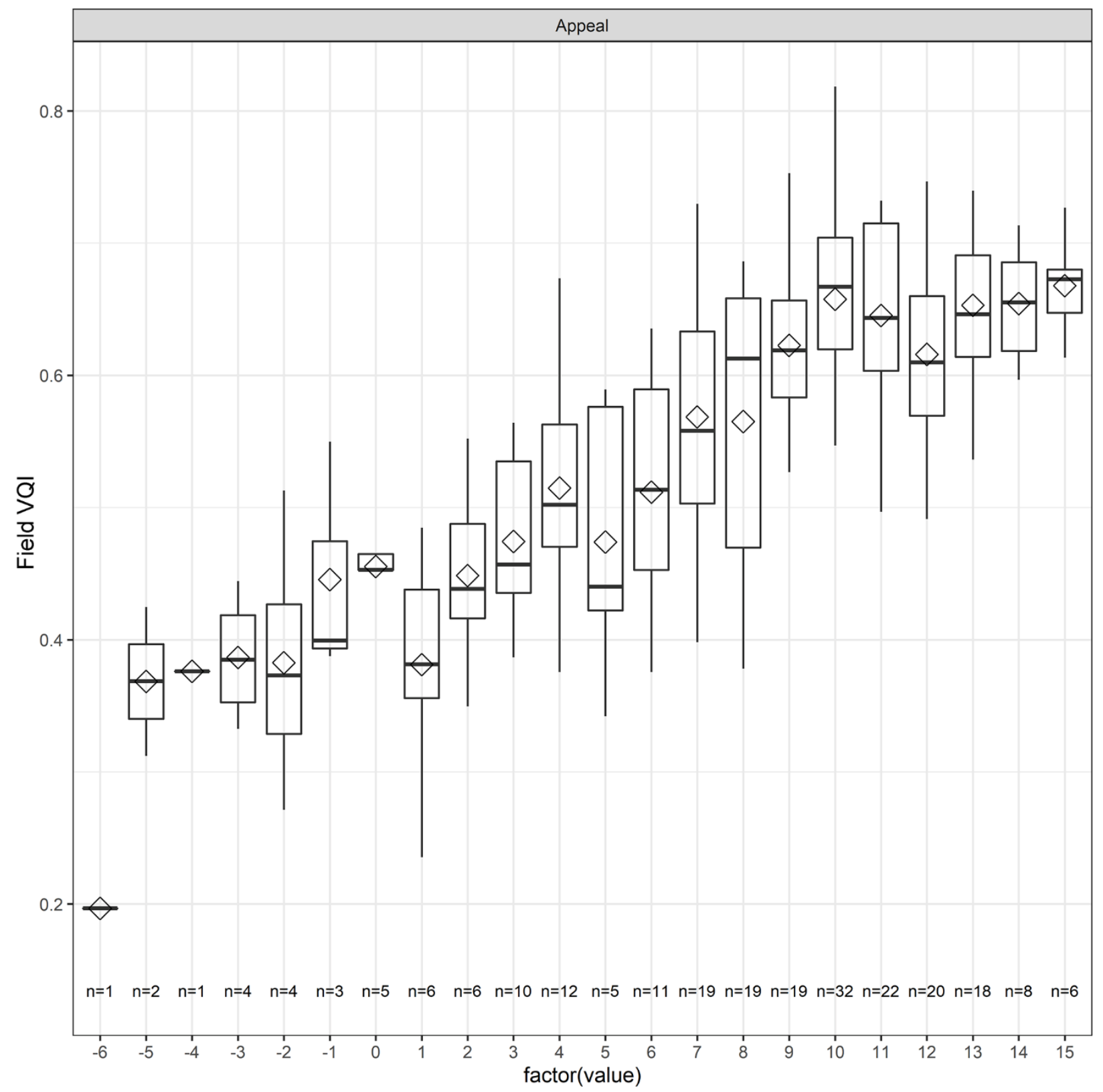

Fig. 4. Overview of the cumulative appeal score (overall appeal) recorded within the qualitative/perceptual component of field visual quality assessment relative to VQI score resulting from its quantitative component. The overall appeal has a theoretical maximum of +15 (all individual appeal categories are rated as +3 ) and a theoretical minimum of -15 (all individual appeal categories are rated as -3). VQI ranges from 0 to $1 ; \mathrm{n}$ indicates the number of field assessments relative to the corresponding factor (appeal score). 


\section{Remote (GIS) visual quality assessment}

The values from the remote (GIS) visual quality assessment carried at $1 \mathrm{~km}^{2}$ range from 0.1 to 0.74 and the range of VQI values increases with increase in scale i.e. on a scale of $2 \mathrm{~km}^{2}$ the VQI ranges from 0.1 to 0.77 , then from 0.1 to 0.84 on a scale of $3 \mathrm{~km}^{2}$ and from 0.21 to 0.86 on a scale of $5 \mathrm{~km}^{2}$. Results from GIS visual assessments are presented in Figure 5a to 5d. Details of the VQI scores of sites with highest VQI ratings according the GIS visual quality assessment are provided in Table S5 in the supplementary material.
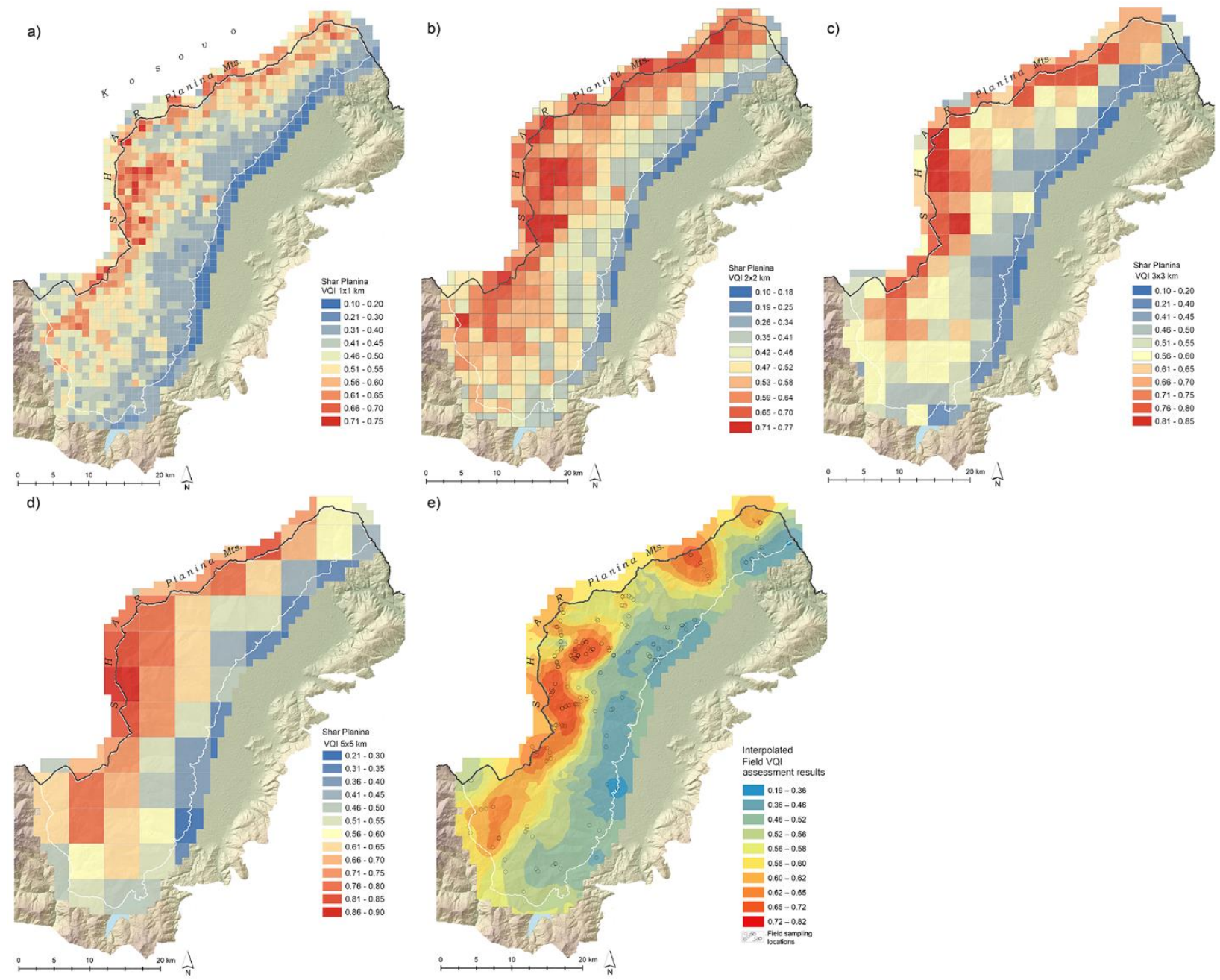

Fig. 5. Remote (GIS) visual quality assessment results for Shar Planina: a) $1 \mathrm{~km}^{2}$; b) $2 \mathrm{~km}^{2}$; and c) $3 \mathrm{~km}^{2}$; d) $5 \mathrm{~km}^{2}$ and e) Interpolated values from the field visual quality assessment 
The GIS visual quality assessment and the field visual quality assessment results (Figure 5 a-e) are strongly correlated with results ranging from 0.60 to 0.72 , scale dependent, with $p=0$ in all cases. Correlation specifics are provided in Figure 6.

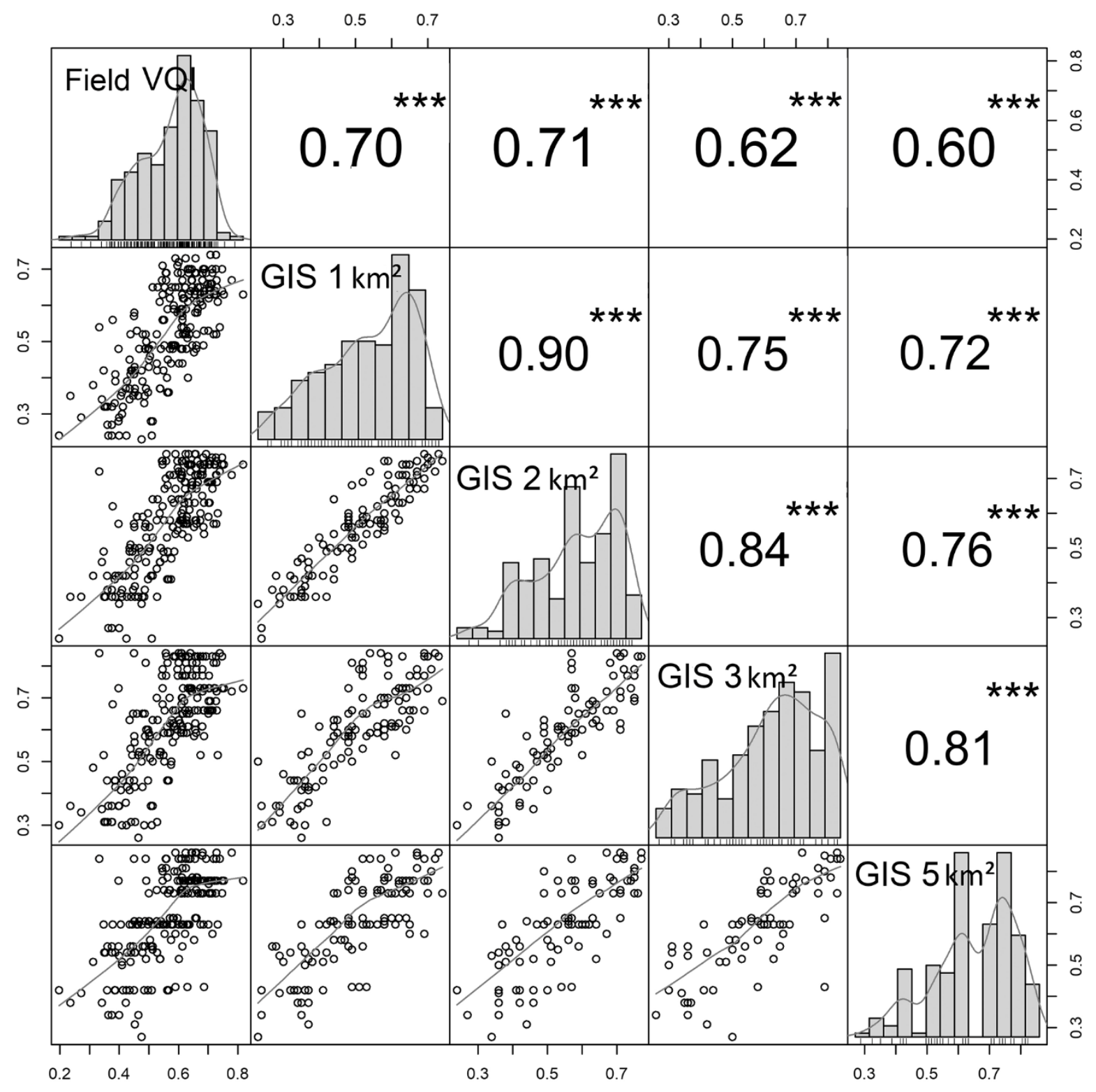

Fig. 6. Correlation matrix of VQI scores between the field visual quality assessment and the corresponding values of GIS visual quality assessment. The value of the correlation $(r)$ and the significance level are indicated on the top of diagonal, three stars meaning $p<0.0000$. 
The remote (GIS) visual quality assessment also provides useful insights into the overall visual quality of the different landscape types (Figure 7). The highest VQI observed within the agricultural/rural landscapes is that in mountain rural landscape (0.71). The highest VQI values observed within the natural landscapes are shared between the mountain grassland landscape on silicate ground with landscape of silicate rocky ground $(0.76)$ and mountain grassland landscape on limestone ground with landscape of limestone rocky ground (0.77). In order to rule out the artificial edge imposed by the applied assessment grid, when interpreting the results one must consider the continuity of view and the visual quality should be interpreted with consideration of the added value of the surrounding cells (Swetnam et al. 2017).

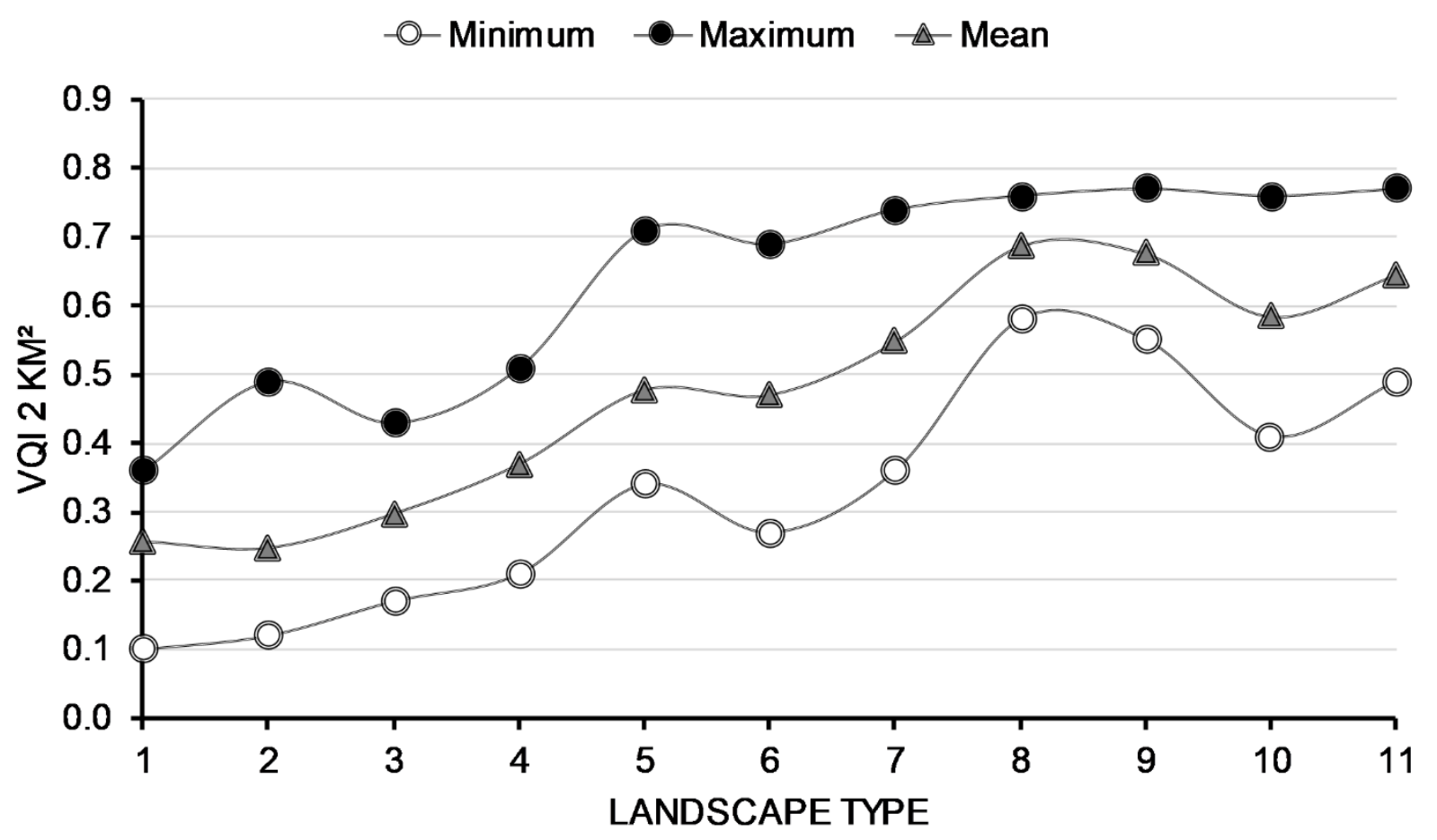

Fig. 7. VQI minimum, maximum and mean values from the remote (GIS) visual quality assessment carried on a scale of $2 \mathrm{~km}^{2}$, found to have strongest correlation with the field based visual quality assessment with reference to different landscape types Landscape types codes: 1 - Urban landscape; 2 - Flatland sub-continental agricultural-rural landscape; 3 - Rolling rural landscape with hedgerows; 4 - Hilly rural landscape; 5 - Mountain rural landscape; 6 - Mesophillous broadleaf forest landscape; 7 - Spruce-fir forest landscape; 8 - Mountain grassland landscape on silicate ground; 9 - Mountain grassland landscape on limestone ground; 10 - Landscape of silicate rocky ground and 11 - Landscape of limestone rocky ground. 


\section{DISCUSSION}

For years, Shar Planina has tempted numerous researchers from the region and abroad to visit and study the abundance of biodiversity hosted by this mountain range. Written impressions on the visual appeal of Shar Planina are contained within the travel writings of researchers and adventurers that date back to the first half of the nineteen century (Boué 1840; also later by Doflein 1921; Krivokapić 1969). Apart from general insights of "beauty" provided as part of these personal observations, there are practically no studies that provide quantitative data on landscape visual quality of Shar Planina. The first quantitative insight into the visual landscape quality in the region is provided by Ramos and Pastor (2012) as part of their efforts to map the visual quality of landscapes in Europe. Their resulting map outlines the particularly high visual quality of landscapes throughout Southeast Europe and appears to classify the visual quality of all mountainous landscapes throughout western North Macedonia as excellent. Considering its coarse scale and wide scope, this visual quality assessment is limited to few physical landscape attributes (terrain, presence of water and land cover) and does not reflect the cultural-historic specifics of land use. In this regard, this study is the first to address the challenge of quantifying the visual quality of mountainous natural and rural landscapes in the region with detailed consideration of both the attributes of the physical environment and associated cultural-historical specifics.

Corresponding trends of the resulting VQI within both quantitative and qualitative components of the field visual quality assessment (Figure 3, Figure 4) confirm that selected metrics provide useful insight into the visual appeal of Shar Planina landscapes. Observed correlation between results from the GIS and the field visual quality assessments (Figure 5 ) indicates that the remote (GIS) visual quality assessment remains representative across range of scales; depicts the consistency in accommodating the criteria applied in the field visual quality assessment and provides evidence of the fitness of the VQI method in remote assessment of visual quality over large spatial extent. When considering the application of the remote (GIS) visual quality assessment across a range of scales, there is a clear trend of increase in VQI scores, especially with reference to the maximum value of the VQI (Figure 5). This is mainly due to the increase in diversity of landscape elements considered in terms of both presence and range. The VQI scores from the field visual quality assessment results were found to be most closely correlated to GIS visual quality assessment carried out on $2 \mathrm{~km}^{2}$ scale and $1 \mathrm{~km}^{2}$. Nonetheless, both $3 \mathrm{~km}^{2}$ and $5 \mathrm{~km}^{2}$ scales have also provided adequate insight into the visual quality of Shar Planina, especially with reference to high mountain areas. 
In general, the visual quality of Shar Planina gradually increases with increase in elevation reflecting an increase in terrain ruggedness and naturalness with a concomitant decrease in human pressures. However, as the VQI calculates the visual quality as a sum of contributing themes, sites with high visual quality are found throughout different landscapes of Shar Planina (Figure 7). The general trend of visual quality observed on Shar Planina is found within a range of quantitative and qualitative studies that focus on (Acar et al. 2006; Otero Pastor et al. 2007; Vizzari 2011; Schirpke et al. 2013) or include mountainous areas (Arriaza et al. 2004; Uzun and Muuml 2011; Frank et al. 2013; Swetnam et al. 2017; Swetnam and Tweed 2018). Observed trends mainly depict the commonalities in ratings that respond to positive contribution of criteria of visual scale and terrain ruggedness or naturalness and negative contribution of disturbance (Ode et al. 2008; Fry et al. 2009). Largely, differences in methodological approaches and landscape specifics impede in-depth comparison of results of visual quality assessments conducted in different regions. Even if there is an alignment in the methodological approach, subtle differences in landscape scale, elevation and specifics of enclosure do mean that approaches to visual quality assessments need to adapt to local and regional specifics. In this regard, most of the adaptations to the VQI method used in the Shar Planina landscape are tailored to address the specifics of the physical landscape (Physical theme) and the "unruly" character of arrangement of landscape elements in rural landscapes (Green space theme and Human/Cultural theme) (Table S1 and Table S2, S3). When assessing landscape visual quality, applied methods should respond to the unique result of interactions of natural and human processes and features that capture the concepts behind landscape appreciation (Fry et al. 2009). The VQI approach to calculating landscape visual quality trialled here allows modifications and alterations and if the design is carefully adapted to the landscapes addressed, the VQI provides an adequate insight into landscape visual quality. However, this is only the case when appropriate groundwork to establish and test the selected assessment criteria has taken place and highly accurate digital data is used as a background to the remote assessment.

As it is a quantitative approach to visual quality, the remote (GIS) visual quality assessment might not capture the specific gradients of socio-cultural particularities reflected in the appearance of rural landscapes. Though the field visual quality assessment is qualitative in part, the appeal ratings were provided by visiting participants with an environmental background and do not capture the nuances in perception and preference of the local population in the region.

Considering the high ethnical and cultural diversity of the local population of Shar Planina (State Statistical Office of the Republic of Macedonia 2002; Fearon 2003) preferences for landscape aesthetics 
can vary amongst different ethnical and socio-cultural groups. In this regard, there is a need for further studies that will examine the role of familiarity, functionality and socio-cultural background of local inhabitants in their perceptions of landscape scenery and associated preferences. Consideration of peoples' perceptions will further allow to determine the particularities that regulate correlations between scenic preference, landscape functionality and the intrinsic ecological value of landscapes and thereby serve as an outline to tailor management practices to address the impact of change on landscape visual quality.

Though landscape visual quality is one of most tangible cultural ecosystem services (Daniel et al. 2012) the quantitative approach to its assessment is still subject to criticism as landscape appeal is also considered to be a result of one's personal judgement (Lothian 1999). Nonetheless, the rising awareness for equating the contribution of cultural ecosystem services within the ecosystem service agenda (Feld et al. 2009; Daniel et al. 2012; Satz et al. 2013) strongly suggests the development of rapid assessments of landscape visual quality in order to provide a baseline from which change can be monitored, measured and subsequently related to scenic quality judgements. Furthermore, as this cultural ecosystem service is being recognised as an important aspect to be incorporated in landscape planning (Council of Europe 2000; Hassan et al. 2005; Daniel et al. 2012) it is noteworthy that conceptually the method allows future refinement of VQI assessment criteria through the use of participatory methods to secure public and stakeholder involvement.

Providing insight into the visual quality of landscapes is particularly important for the developing Southeast European countries, especially with reference to mountainous landscapes that straddle borders and are of high conservational importance (Council of Europe 2006), like Shar Planina. Striving to catch up with the developed economies of Western Europe, North Macedonia struggles to reconcile its ambition for socio-economic development and nature conservation while policy implementation lags behind (European Parliament 2019). Considering the increased pressures when it comes to the utilization of natural resources, this study outlines the role that cultural ecosystem services need to take alongside more traditional environmental measures in the valorisation, management and planning of conservationally important areas. Bearing in mind the initiative for establishing a protected area on Shar Planina, this study provides a background for integrated conservational approach of landscapes and their perceived qualities, allowing consideration of visual quality within further integral systematic environmental and socio-economic assessments. 
The landscape quality assessment provided in this study is the first research of this kind in Southeast Europe and provides a robust baseline from which the impacts of further landscape change can be monitored and evaluated. Considering the commonalities of both natural and cultural landscapes of mountain ranges in the Balkans, adaptations of the VQI method (Swetnam et al. 2017; Swetnam and Tweed 2018) could be applied elsewhere in the region. In view of the socio-political and economic struggles in the region, studies of this type could aid policy implementation and provide an effective framework for land management and planning with respect to nature conservation.

\section{CONCLUSIONS}

This research confirms that quantitative GIS visual quality assessment enables a rapid overview of landscape visual quality with output that strongly correlates with field visual quality assessment. Although, the results from the GIS visual quality assessment vary with scale, the pattern of the general output remains unchanged demonstrating that the VQI remains representative across range of scales and provides evidence of the fitness of the VQI method in remote assessment of visual quality over large spatial extent. The VQI recorded within the quantitative component of field visual quality assessment reflects landscape appeal provided within its qualitative/perceptual component. Conceptually the method allows future refinement of $\mathrm{VQI}$ assessment criteria through the use of participatory methods to secure public and stakeholder involvement. As such, the study provides detailed and inclusive approach to landscape visual quality assessment thereby contributing to the development of effective quantitative means (indicators) and their transferability to aid assessment of cultural ecosystem services and equate their contribution in overall ecosystem service assessment.

Visual quality assessment results derived from both remote (GIS) and field visual quality assessments clearly identify the areas of high visual landscape quality. Furthermore, when aligned with Shar Planina landscapes, the VQI provides useful insights into the overall landscape quality associated with different landscape types and can guide the selection of areas for conservation. Within the context of the ongoing initiative to establish a protected area on Shar Planina, this method provides a baseline for monitoring of this important cultural ecosystem service and allows its full consideration in the conservation policy and management plan of the future National park.

\section{REFERENCES}

Acar C, Kurdoglu BC, Kurdoglu O, Acar H (2006) Public preferences for visual quality and management in the Kackar Mountains National Park (Turkey). International Journal of Sustainable Development \& World Ecology 13:499-512 . https://doi.org/10.1080/13504500609469699 
Arias-García J, Serrano-Montes JL, Gómez-Zotano J (2016) Fauna in wetland landscapes: a perception approach. Landscape Research 41:510-523 . https://doi.org/10.1080/01426397.2015.1081160

Arriaza M, Cañas-Ortega JF, Cañas-Madueño JA, Ruiz-Aviles P (2004) Assessing the visual quality of rural landscapes. Landscape and Urban Planning 69:115-125 . https://doi.org/10.1016/j.landurbplan.2003.10.029

Boué A (1840) La Turquie d’Europe; observations sur la geographie, la géologie, l'histoire naturelle, la statistique, les moeurs, les coutumes, l'achéologie, l'agriculture, l'industrie, le commerce, les gouvernements divers, le clergé, l'histoire et l'etat de cet empire,. Arthus Bertrand, Paris

Bulut Z, Karahan F (2010) Determining visual beauties of natural waterscapes: A case study for Tortum Valley (Erzurum/Turkey). Sci Res Essays 5:170-182

Council of Europe (1996) Pan-European Biological and Landscape Diversity Strategy

Council of Europe (2000) European landscape convention (European Treaty Series, no.176, Florence Convention). Strasbourg

Council of Europe (2006) Landscape and sustainable development: challenges of the European Landscape Convention. Council of Europe, Strasbourg

Dakin S (2003) There's more to landscape than meets the eye: towards inclusive landscape assessment in resource and environmental management. The Canadian Geographer/Le Géographe canadien 47:185-200

Daniel TC (2001) Whither scenic beauty? Visual landscape quality assessment in the 21st century. Landscape and urban planning 54:267-281

Daniel TC, Muhar A, Arnberger A, Aznar O, Boyd JW, Chan KMA, Costanza R, Elmqvist T, Flint CG, Gobster PH, Gret-Regamey A, Lave R, Muhar S, Penker M, Ribe RG, Schauppenlehner T, Sikor T, Soloviy I, Spierenburg M, Taczanowska K, Tam J, von der Dunk A (2012) Contributions of cultural services to the ecosystem services agenda. Proceedings of the National Academy of Sciences 109:8812-8819 . https://doi.org/10.1073/pnas.1114773109

De Pablo CL, Roldán-Martín MJ, De Agar PM (2012) Magnitude and Significance in Landscape Change. Landscape Research 37:571-589 . https://doi.org/10.1080/01426397.2011.641949

Despodovska A, Arsovska B, Melovski L, Hristovski S (2012) Land use changes on Galicica Mountain. In: Proceedings of the 4th Congress of Ecologists of Macedonia with International Participation. Macedonian Ecological Society, Ohrid, pp 163-166

Díaz S, Demissew S, Joly C, Lonsdale WM, Larigauderie A (2015) A Rosetta Stone for Nature's Benefits to People. PLOS Biology 13:e1002040 . https://doi.org/10.1371/journal.pbio.1002040

Díaz S, Pascual U, Stenseke M, Martín-López B, Watson RT, Molnár Z, Hill R, Chan KMA, Baste IA, Brauman KA, Polasky S, Church A, Lonsdale M, Larigauderie A, Leadley PW, van Oudenhoven APE, van der Plaat F, Schröte M, Lavorel S, Aumeeruddy-Thomas ildiz, Bukvareva E, Davies K, Demissew S, Erpul G, Failler P, Guerra CA, Hewitt CL, Keune H, Lindley S, Shirayama Y (2018) Assessing nature's 
contributions to people. Recognizing culture, and diverse sources of knowledge, can improve assessments. Science 359:270-272 . https://doi.org/10.1126/science.aap8826

Doflein F (1921) Mazedonien: erlebnisse und beobachtungen eines naturforschers im gefolge des deutschen heeres. Gustav Fisher, Jena

Dramstad WE, Tveit MS, Fjellstad WJ, Fry GLA (2006) Relationships between visual landscape preferences and map-based indicators of landscape structure. Landscape and Urban Planning 78:465-474 . https://doi.org/10.1016/j.landurbplan.2005.12.006

EEA (2018) Corine Land Cover, 2018. In: Copernicus Land Monitoring Service. https://land.copernicus.eu/pan-european/corine-land-cover. Date accessed 30/01/2019. https://land.copernicus.eu/pan-european/corine-land-cover. Accessed 30 Jan 2019

ESA Sentinel-2. In: European Space Agency. https://www.esa.int/Our_Activities/Observing_the_Earth/Copernicus/Sentinel-2. Accessed 30 Jan 2019

European Parliament (2019) European Parliament resolution of 29 November 2018 on the 2018 Commission Report on the former Yugoslav Republic of Macedonia (2018/2145(INI)

Falcucci A, Maiorano L, Boitani L (2006) Changes in land-use/land-cover patterns in Italy and their implications for biodiversity conservation. Landscape Ecology 22:617-631 . https://doi.org/10.1007/s10980-006-9056-4

Fearon JD (2003) Ethnic and Cultural Diversity by Country. Journal of Economic Growth 8:195-222

Feld CK, Martins da Silva P, Paulo Sousa J, de Bello F, Bugter R, Grandin U, Hering D, Lavorel S, Mountford O, Pardo I, Pärtel M, Römbke J, Sandin L, Bruce Jones K, Harrison P (2009) Indicators of biodiversity and ecosystem services: a synthesis across ecosystems and spatial scales. Oikos 118:1862-1871 . https://doi.org/10.1111/j.1600-0706.2009.17860.x

Ferrari C, Pezzi G, Diani L, Corazza M (2008) Evaluating landscape quality with vegetation naturalness maps: an index and some inferences. Applied Vegetation Science 11:243-250 . https://doi.org/10.3170/2008-7-18400

Frank S, Fürst C, Koschke L, Witt A, Makeschin F (2013) Assessment of landscape aesthetics-Validation of a landscape metrics-based assessment by visual estimation of the scenic beauty. Ecological Indicators 32:222-231 . https://doi.org/10.1016/j.ecolind.2013.03.026

Fry G, Tveit MS, Ode å., Velarde MD (2009) The ecology of visual landscapes: Exploring the conceptual common ground of visual and ecological landscape indicators. Ecological Indicators 9:933-947 . https://doi.org/10.1016/j.ecolind.2008.11.008

García-Llorente M, Martín-López B, Iniesta-Arandia I, López-Santiago CA, Aguilera PA, Montes C (2012) The role of multi-functionality in social preferences toward semi-arid rural landscapes: An ecosystem service approach. Environmental Science \& Policy 19-20:136-146 . https://doi.org/10.1016/j.envsci.2012.01.006 
Garré S, Meeus S, Gulinck H (2009) The dual role of roads in the visual landscape: A case-study in the area around Mechelen (Belgium). Landscape and Urban Planning 92:125-135. https://doi.org/10.1016/j.landurbplan.2009.04.001

Gobster PH, Nassauer JI, Daniel TC, Fry G (2007) The shared landscape: what does aesthetics have to do with ecology? Landscape Ecology 22:959-972 . https://doi.org/10.1007/s10980-007-9110-x

Grêt-Regamey A, Bishop ID, Bebi P (2007) Predicting the scenic beauty value of mapped landscape changes in a mountainous region through the use of GIS. Environment and Planning B: Planning and Design 34:50-67 . https://doi.org/10.1068/b32051

Gulinck H, Múgica M, de Lucio JV, Atauri JA (2001) A framework for comparative landscape analysis and evaluation based on land cover data, with an application in the Madrid region (Spain). Landscape and Urban Planning 55:257-270 . https://doi.org/10.1016/S0169-2046(01)00159-1

Hassan RM, Scholes RJ, Ash N (eds) (2005) Ecosystems and human well-being: current state and trends. Island Press, Washington, DC

Howley P (2011) Landscape aesthetics: Assessing the general publics' preferences towards rural landscapes. Ecological Economics 72:161-169 . https://doi.org/10.1016/j.ecolecon.2011.09.026

Howley P, Donoghue CO, Hynes S (2012) Exploring public preferences for traditional farming landscapes. Landscape and Urban Planning 104:66-74 . https://doi.org/10.1016/j.landurbplan.2011.09.006

Hunziker M, Felber P, Gehring K, Buchecker M, Bauer N, Kienast F (2008) Evaluation of Landscape Change by Different Social Groups: Results of Two Empirical Studies in Switzerland. Mountain Research and Development 28:140-147 . https://doi.org/10.1659/mrd.0952

Jepsen MR, Kuemmerle T, Müller D, Erb K, Verburg PH, Haberl H, Vesterager JP, Andrič M, Antrop M, Austrheim G, Björn I, Bondeau A, Bürgi M, Bryson J, Caspar G, Cassar LF, Conrad E, Chromý P, Daugirdas V, Van Eetvelde V, Elena-Rosselló R, Gimmi U, Izakovicova Z, Jančák V, Jansson U, Kladnik D, Kozak J, Konkoly-Gyuró E, Krausmann F, Mander Ü, McDonagh J, Pärn J, Niedertscheider M, Nikodemus O, Ostapowicz K, Pérez-Soba M, Pinto-Correia T, Ribokas G, Rounsevell M, Schistou D, Schmit C, Terkenli TS, Tretvik AM, Trzepacz P, Vadineanu A, Walz A, Zhllima E, Reenberg A (2015) Transitions in European land-management regimes between 1800 and 2010. Land Use Policy 49:53-64 . https://doi.org/10.1016/j.landusepol.2015.07.003

Jovanovska D (2019) Use of Sentinel-2 for land cover classification on Shar Planina, North Macedonia. Mendeley Data v1: . https://doi.org/10.17632/3628s8bpff.1

Jovanovska D, Melovski L (2012) Land cover succession as a result of changing land use practises in Northeast Macedonia. In: Proceedings of the 4th Congress of Ecologists of Macedonia with International Participation. Macedonian Ecological Society, Ohrid, pp 185-196

Kaplan A, Taşkın T, Önenç A (2006) Assessing the Visual Quality of Rural and Urban-fringed Landscapes surrounding Livestock Farms. Biosystems Engineering 95:437-448 . https://doi.org/10.1016/j.biosystemseng.2006.07.011

Krivokapić D (1969) Šar-planina - turističko-geografski prikaz predela i naroda. Turistička štampa, Beograd 
Lambin EF, Turner BL, Geist HJ, Agbola SB, Angelsen A, Bruce JW, Coomes OT, Dirzo R, Fischer G, Folke C (2001) The causes of land-use and land-cover change: moving beyond the myths. Global environmental change 11:261-269

Lazarevski A (1993) Climate in Macedonia. Kultura, Skopje

Lothian A (1999) Landscape and the philosophy of aesthetics: is landscape quality inherent in the landscape or in the eye of the beholder? Landscape and urban planning 44:177-198

Meeus JHA, Wijermans MP, Vroom MJ (1990) Agricultural landscapes in Europe and their transformation. Landscape and Urban Planning 18:289-352 . https://doi.org/10.1016/0169-2046(90)90016-U

Melovski L, Hristovski S, Melovski D, Kolchakovski D, Velevski M, Angelova N, Levkov Z, Karadelev M (2010) Natural Values of Shar Planina Mt. Macedonian Ecological Society, Skopje

Melovski L, Jovanovska D, Hristovski S (2019) Landscape diversity in North Macedonia. Macedonian Journal of Ecology and Environment 21:35-64

Melovski L, Markoski B, Hristovski S, Jovanovska D, Anastasovski V, Klincharov S, Velevski M, Velkovski N, Trendafilov A, Matevski V, Kostadinovski M, Karadelev M, Levkov Z, Kolchakovski D (2013) Regional division of the Republic of Macedonia for the needs of biological databases. Macedonian Journal of Ecology and Environment 15:81-111

Mücher CA, Klijn JA, Wascher DM, Schaminée JHJ (2010) A new European Landscape Classification (LANMAP): A transparent, flexible and user-oriented methodology to distinguish landscapes. Ecological Indicators 10:87-103 . https://doi.org/10.1016/j.ecolind.2009.03.018

Ode Å, Fry G, Tveit MS, Messager P, Miller D (2009) Indicators of perceived naturalness as drivers of landscape preference. Journal of Environmental Management 90:375-383 . https://doi.org/10.1016/j.jenvman.2007.10.013

Ode Å, Hagerhall CM, Sang N (2010) Analysing Visual Landscape Complexity: Theory and Application. Landscape Research 35:111-131 . https://doi.org/10.1080/01426390903414935

Ode Å, Miller D (2011) Analysing the relationship between indicators of landscape complexity and preference. Environment and Planning B: Planning and Design 38:24-40 . https://doi.org/10.1068/b35084

Ode Å, Tveit MS, Fry G (2008) Capturing Landscape Visual Character Using Indicators: Touching Base with Landscape Aesthetic Theory. Landscape Research 33:89-117 . https://doi.org/10.1080/01426390701773854

Otero Pastor I, Casermeiro Martínez MA, Ezquerra Canalejoa A, Esparcia Mariño P (2007) Landscape evaluation: Comparison of evaluation methods in a region of Spain. Journal of Environmental Management 85:204-214 . https://doi.org/10.1016/j.jenvman.2006.09.018

Pecher C, Bacher M, Tasser E, Tappeiner U (2018) Agricultural landscapes between intensification and abandonment: the expectations of the public in a Central-Alpine cross-border region. Landscape Research 43:428-442 . https://doi.org/10.1080/01426397.2017.1315062 
Perko D, Ciglič R (2015) Slovenia as a European landscape hotspot. AGB 1:45-54 . https://doi.org/10.18509/AGB.2015.05

Plieninger T, Dijks S, Oteros-Rozas E, Bieling C (2013) Assessing, mapping, and quantifying cultural ecosystem services at community level. Land Use Policy 33:118-129 . https://doi.org/10.1016/j.landusepol.2012.12.013

Price C (2013) Subjectivity and objectivity in landscape evaluation: an old topic revisited. In: van der Heide CM, Heijman WJM (eds) The Economic Value of Landscapes, 1st edn. Routledge, London, pp 5376

Purcell AT, Lamb RJ (1998) Preference and naturalness: An ecological approach. Landscape and Urban Planning 42:57-66 . https://doi.org/10.1016/S0169-2046(98)00073-5

Ramos BM, Pastor IO (2012) Mapping the visual landscape quality in Europe using physical attributes. Journal of Maps 8:56-61 . https://doi.org/10.1080/17445647.2012.668763

Rechtman O (2013) Visual Perception of Agricultural Cultivated Landscapes: Key Components as Predictors for Landscape Preferences. Landscape Research 38:273-294 . https://doi.org/10.1080/01426397.2012.672639

Rogge E, Nevens F, Gulinck H (2007) Perception of rural landscapes in Flanders: Looking beyond aesthetics. Landscape and Urban Planning 82:159-174 . https://doi.org/10.1016/j.landurbplan.2007.02.006

Sari D, Acar C (2016) Visual Landscape Assessment of the Alpine Rocky Habitats: A Case Study of Hatila Valley National Park, Artvin, Turkey. In: Efe R, Cürebal I, Gad A, Tóth B (eds) Environmental Sustainability and Landscape Management. St. Kliment Ohridski University Press, Sofia, pp 1-34

Satz D, Gould RK, Chan KMA, Guerry A, Norton B, Satterfield T, Halpern BS, Levine J, Woodside U, Hannahs N, Basurto X, Klain S (2013) The Challenges of Incorporating Cultural Ecosystem Services into Environmental Assessment. AMBIO 42:675-684 . https://doi.org/10.1007/s13280-013-03866

Schirpke U, Tasser E, Tappeiner U (2013) Predicting scenic beauty of mountain regions. Landscape and Urban Planning 111:1-12 . https://doi.org/10.1016/j.landurbplan.2012.11.010

State Statistical Office of the Republic of Macedonia (2012) Regions in the Republic of Macedonia, 2012. Skopje

State Statistical Office of the Republic of Macedonia (2002) Census of population, households and dwellings in the Republic of Macedonia. Skopje

Swetnam RD, Harrison-Curran SK, Smith GR (2017) Quantifying visual landscape quality in rural Wales: A GIS-enabled method for extensive monitoring of a valued cultural ecosystem service. Ecosystem Services 26:451-464 . https://doi.org/10.1016/j.ecoser.2016.11.004

Swetnam RD, Tweed FS (2018) A tale of two landscapes: Transferring landscape quality metrics from Wales to Iceland. Land Use Policy 76:565-576 . https://doi.org/10.1016/j.landusepol.2018.02.037 
Tengberg A, Fredholm S, Eliasson I, Knez I, Saltzman K, Wetterberg O (2012) Cultural ecosystem services provided by landscapes: Assessment of heritage values and identity. Ecosystem Services 2:14-26 . https://doi.org/10.1016/j.ecoser.2012.07.006

Tratalos JA, Haines-Young R, Potschin M, Fish R, Church A (2016) Cultural ecosystem services in the UK: Lessons on designing indicators to inform management and policy. Ecological Indicators 61:63-73 . https://doi.org/10.1016/j.ecolind.2015.03.040

Turner BL, Lambin EF, Reenberg A (2007) The emergence of land change science for global environmental change and sustainability. Proceedings of the National Academy of Sciences 104:20666-20671

Tveit M, Ode $\AA$, Fry G (2006) Key concepts in a framework for analysing visual landscape character. Landscape Research 31:229-255 . https://doi.org/10.1080/01426390600783269

Uzun O, Muuml H (2011) Visual landscape quality in landscape planning: Examples of Kars and Ardahan cities in Turkey. African Journal of Agricultural Research 6:1627-1638

van der Jagt APN, Craig T, Anable J, Brewer MJ, Pearson DG (2014) Unearthing the picturesque: The validity of the preference matrix as a measure of landscape aesthetics. Landscape and Urban Planning 124:1-13 . https://doi.org/10.1016/j.landurbplan.2013.12.006

Vizzari M (2011) Spatial modelling of potential landscape quality. Applied Geography 31:108-118 . https://doi.org/10.1016/j.apgeog.2010.03.001 


\section{LIST OF SUPPLEMENTARY MATERIALS}

S1: Detailed overview of component metrics and assessment specifics applied in the field assessment of the Visual Quality Index (VQI)

S2: Detailed overview of component metrics and assessment specifics applied in the remote (GIS) visual quality assessment

S3: VQI calculation and themes weighting sensitivity analysis

S4: VQI field evaluation examples of landscape views assessed by more than one participant and associated personal responses for visual appeal including comparative presentation of corresponding remote (GIS) VQI scores

S5: Details of visual quality ratings of sites with highest VQI scores (VQI $\geq 0.60$ ) according to the GIS visual quality assessment applied on a scale of $2 \mathrm{~km}^{2}$.

S6: Supplementary Material References 


\section{S1: Detailed overview of component metrics and assessment specifics applied in the field assessment of the Visual Quality Index (VQI)}

\begin{tabular}{|c|c|c|c|c|}
\hline OBSERVER: & \multicolumn{4}{|l|}{ Free entry } \\
\hline DATE/TIME: & \multicolumn{4}{|c|}{ Current date/time obtained by default } \\
\hline COORDINATES: & \multicolumn{4}{|c|}{ Current location obtained by default } \\
\hline LOCALITY: & \multicolumn{4}{|l|}{ Free entry } \\
\hline ORIENTATION: & \multicolumn{4}{|l|}{ Free entry } \\
\hline \multicolumn{5}{|l|}{ PHYSICAL } \\
\hline \multirow[b]{2}{*}{ Q1 } & \multicolumn{4}{|c|}{ How rugged is the majority of the landscape? } \\
\hline & $\begin{array}{l}\text { Level or } \\
\text { nearly level } \\
\text { (1) }\end{array}$ & $\begin{array}{l}\text { Undulating } \\
\qquad(2)\end{array}$ & $\begin{array}{l}\text { Moderately } \\
\text { rugged } \\
\text { (3) }\end{array}$ & $\begin{array}{l}\text { Highly rugged } \\
\text { (4) }\end{array}$ \\
\hline \multirow[b]{2}{*}{ Q2 } & \multicolumn{4}{|c|}{ Can you see any rocky areas or screes? } \\
\hline & $\begin{array}{l}\text { No } \\
(0)\end{array}$ & \multicolumn{3}{|l|}{ Yes } \\
\hline \multirow{2}{*}{ Q3 } & \multicolumn{4}{|c|}{$\begin{array}{l}\text { Are the rocky areas silicate (dark in colour) or limestone (white to light } \\
\text { gray coloured)? }\end{array}$} \\
\hline & $\begin{array}{l}\text { Silicate } \\
(0)\end{array}$ & \multicolumn{3}{|l|}{$\begin{array}{l}\text { Limestone } \\
\text { (1) }\end{array}$} \\
\hline
\end{tabular}

\section{BLUE SPACE}

Can you see any rivers or streams?

Q4

\section{Can you see any rivers or streams?}

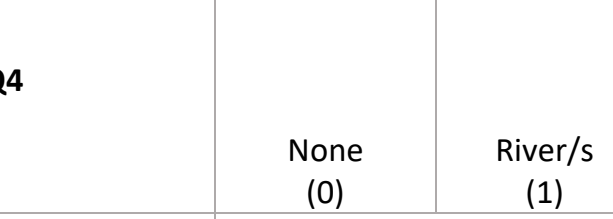

\begin{tabular}{c|c|c|}
\hline Q5 & \multicolumn{2}{|c|}{ Can you see any lakes or waterfalls? } \\
\hline & No & Yes \\
& $(0)$ & $(1)$ \\
\hline
\end{tabular}

Q6 What \% of the landscape consists of liquid water?

\begin{tabular}{|c|c|c|c|c|c|c|}
\hline & \multicolumn{5}{|c|}{ What $\%$ of the landscape consists of liquid water? } & \multirow[t]{2}{*}{ Iceland } \\
\hline & $\begin{array}{c}0 \\
(0)\end{array}$ & $\begin{array}{l}<10 \% \\
(1)\end{array}$ & $\begin{array}{c}10-25 \% \\
(2)\end{array}$ & $\begin{array}{c}26-50 \% \\
(3)\end{array}$ & $\begin{array}{c}51-100 \% \\
\text { (not applicable) }\end{array}$ & \\
\hline \multirow[t]{2}{*}{ Q7 } & \multicolumn{5}{|c|}{ Can you see any remaining snow patches? } & \multirow[t]{2}{*}{ Shared for Shar Planina and Iceland } \\
\hline & $\begin{array}{l}\text { No } \\
(0)\end{array}$ & $\begin{array}{l}\text { Yes } \\
(1)\end{array}$ & & & & \\
\hline \multicolumn{7}{|c|}{ GREEN SPACE } \\
\hline \multirow[t]{2}{*}{ Q8 } & \multicolumn{5}{|c|}{ What $\%$ of the landscape is represented by forests? } & Shared for Shar Planina and Wales \\
\hline & $\begin{array}{c}0 \\
(0)\end{array}$ & $\begin{array}{l}<10 \% \\
(1)\end{array}$ & $\begin{array}{c}10-25 \% \\
(2)\end{array}$ & $\begin{array}{c}26-50 \% \\
(3)\end{array}$ & $\begin{array}{l}51-100 \% \\
(4)\end{array}$ & \\
\hline \multirow[t]{2}{*}{ Q9 } & \multicolumn{5}{|c|}{$\begin{array}{l}\text { What } \% \text { of the landscape is represented by natural grasslands i.e. } \\
\text { pastures? }\end{array}$} & \multirow{2}{*}{$\begin{array}{l}\text { Shared for Shar Planina, Wales and } \\
\text { Iceland. In the case of Wales and } \\
\text { Iceland referred to as the overall \% } \\
\text { of vegetated land in the view }\end{array}$} \\
\hline & $\begin{array}{c}0 \\
(0)\end{array}$ & $\begin{array}{l}<10 \% \\
(1)\end{array}$ & $\begin{array}{c}10-25 \% \\
(2)\end{array}$ & $\begin{array}{c}26-50 \% \\
(3)\end{array}$ & $\begin{array}{l}51-100 \% \\
(4)\end{array}$ & \\
\hline \multirow[t]{2}{*}{ Q10 } & \multicolumn{5}{|c|}{ Can you see any wetlands } & \multirow[t]{2}{*}{ Shar Planina specific (see GS3 in S2) } \\
\hline & $\begin{array}{l}\text { No } \\
(0)\end{array}$ & $\begin{array}{l}\text { Yes } \\
(1)\end{array}$ & & & & \\
\hline Q11 & \multicolumn{5}{|c|}{ Vegetation is diverse (herbaceous plants, flowers, ferns, trees)? } & \\
\hline
\end{tabular}




\begin{tabular}{|c|c|c|c|c|c|c|}
\hline & $\begin{array}{l}\text { No } \\
(0)\end{array}$ & \multicolumn{4}{|l|}{$\begin{array}{l}\text { Yes } \\
(1)\end{array}$} & $\begin{array}{l}\text { Shar Planina specific, but associated } \\
\text { to flowering plants (Wales and } \\
\text { Iceland) and individual large trees } \\
\text { (Wales) }\end{array}$ \\
\hline \multirow[t]{2}{*}{ Q12 } & \multicolumn{5}{|c|}{ Can you see or sense presence of wildlife (animals, birds)? } & \multirow{2}{*}{$\begin{array}{l}\text { Shared for Shar Planina and Iceland, } \\
\text { but in the case of Shar Planina } \\
\text { livestock presence is assessed as a } \\
\text { cultural specific. Instead, here we } \\
\text { include presence of all wildlife, as } \\
\text { wildlife encounters are common. }\end{array}$} \\
\hline & $\begin{array}{l}\text { No } \\
(0)\end{array}$ & $\begin{array}{l}\text { Yes } \\
(1)\end{array}$ & & & & \\
\hline \multirow[t]{2}{*}{ Q13 } & \multicolumn{5}{|c|}{ Can you give a number of distinctive land covers/habitats? } & \multirow{2}{*}{$\begin{array}{l}\text { Shar Planina specific, associated to } \\
\text { habitat diversity }\end{array}$} \\
\hline & $\begin{array}{c}1 \\
(1)\end{array}$ & $\begin{array}{c}2 \\
(2)\end{array}$ & $\begin{array}{c}3 \\
(3)\end{array}$ & $\begin{array}{c}4 \\
(4)\end{array}$ & $\begin{array}{c}5 \\
(5)\end{array}$ & \\
\hline \multirow[t]{2}{*}{ Q14 } & \multicolumn{5}{|c|}{ Do you see any agricultural land (fields and/or meadows)? } & \multirow[t]{2}{*}{ Shar Planina specific } \\
\hline & $\begin{array}{l}\text { No } \\
(0)\end{array}$ & $\begin{array}{l}\text { Yes } \\
(1)\end{array}$ & & & & \\
\hline \multirow[t]{2}{*}{ Q15 } & \multicolumn{5}{|c|}{ Agricultural land type } & \multirow[t]{2}{*}{ Shar Planina specific } \\
\hline & $\begin{array}{l}\text { None } \\
(0)\end{array}$ & $\begin{array}{l}\text { Intensive } \\
\text { (1) }\end{array}$ & $\begin{array}{l}\text { Intensive } \\
\text { diverse } \\
(2)\end{array}$ & $\begin{array}{l}\text { Extensive } \\
\text { (3) }\end{array}$ & & \\
\hline \multirow[t]{2}{*}{ Q16 } & \multicolumn{5}{|c|}{ If hedgerows are present, what is their arrangement type? } & \multirow{4}{*}{$\begin{array}{l}\text { Shar Planina specific, but associated } \\
\text { to Wales that refers to presence } \\
\text { and length of hedgerows in the } \\
\text { view }\end{array}$} \\
\hline & $\begin{array}{l}\text { No } \\
\text { hedgerows } \\
\text { (0) }\end{array}$ & $\begin{array}{l}\text { Linear } \\
\text { scarce } \\
(1)\end{array}$ & $\begin{array}{l}\text { Veneering } \\
\text { (unruly) } \\
(2)\end{array}$ & $\begin{array}{l}\text { Tidy } \\
\text { (3) }\end{array}$ & & \\
\hline \multirow[t]{2}{*}{ Q17 } & \multicolumn{5}{|c|}{ Hedgerow type } & \\
\hline & $\begin{array}{l}\text { None/Grassy } \\
\text { (0) }\end{array}$ & $\begin{array}{l}\text { Scrubs } \\
\text { (1) }\end{array}$ & $\begin{array}{c}\text { Trees } \\
(2)\end{array}$ & & & \\
\hline \multicolumn{7}{|c|}{ HUMAN/CULTURAL } \\
\hline \multirow[t]{2}{*}{ Q18 } & \multicolumn{5}{|c|}{ What \% of the landscape in the view is build/artificial? } & \multirow{4}{*}{$\begin{array}{l}\text { Shar Planina specific as it considers } \\
\text { both the \% in the view that is } \\
\text { build/artificial whilst also } \\
\text { considering the type of } \\
\text { infrastructure. } \\
\text { Associated to Wales that refers to \% } \\
\text { of landscape in the view that is } \\
\text { urban/suburban and Iceland that } \\
\text { refers to presence of buildings in the } \\
\text { view }\end{array}$} \\
\hline & $\begin{array}{c}0 \\
(4)\end{array}$ & $\begin{array}{c}<10 \% \\
(3)\end{array}$ & $\begin{array}{c}10-25 \% \\
(2)\end{array}$ & $\begin{array}{l}26-50 \% \\
(1)\end{array}$ & $\begin{array}{l}51-100 \% \\
(0)\end{array}$ & \\
\hline Q19 & What is the ty & e of infrastru & ure? & & & \\
\hline & $\begin{array}{l}\text { None } \\
(4)\end{array}$ & $\begin{array}{c}\text { Rural } \\
\text { (3) }\end{array}$ & $\begin{array}{l}\text { Tourist } \\
\text { settlement } \\
(2)\end{array}$ & $\begin{array}{l}\text { Rural } \\
\text { urbanised } \\
\text { (1) }\end{array}$ & $\begin{array}{l}\text { Urban } \\
\text { (0) }\end{array}$ & \\
\hline \multirow[t]{2}{*}{ Q20 } & \multicolumn{5}{|c|}{$\begin{array}{l}\text { Do you see any other individual bits of infrastructure (large pylons, } \\
\text { piping and water catchments)? }\end{array}$} & \multirow[t]{2}{*}{$\begin{array}{l}\text { Shared for Shar Planina, Wales and } \\
\text { Iceland }\end{array}$} \\
\hline & $\begin{array}{l}\text { No } \\
(1)\end{array}$ & $\begin{array}{l}\text { Yes } \\
\text { (0) }\end{array}$ & 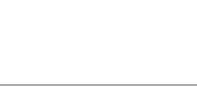 & & & \\
\hline \multirow[t]{2}{*}{ Q21 } & \multicolumn{5}{|c|}{ Are there any roads in the view? } & \multirow{2}{*}{$\begin{array}{l}\text { Shared for Shar Planina, Wales and } \\
\text { Iceland in terms of assessing } \\
\text { presence or absence of roads in the } \\
\text { view. In the case of Shar Planina } \\
\text { and Iceland, the type of road is also } \\
\text { considered }\end{array}$} \\
\hline & $\begin{array}{l}\text { None or } \\
\text { paths } \\
(2)\end{array}$ & $\begin{array}{l}\text { Gravel/dirt } \\
\text { roads } \\
(1)\end{array}$ & $\begin{array}{l}\text { Asphalt road } \\
\text { (0) }\end{array}$ & & & \\
\hline \multirow[t]{2}{*}{ Q22 } & \multicolumn{5}{|c|}{ Can you see any sheepfolds? } & \multirow{2}{*}{$\begin{array}{l}\text { Shar Planina specific, in the case of } \\
\text { Wales and Iceland considered as } \\
\text { general assessment of presence of } \\
\text { buildings of architectural or cultural } \\
\text { interest or merit }\end{array}$} \\
\hline & $\begin{array}{l}\text { No } \\
(0)\end{array}$ & $\begin{array}{l}\text { Yes } \\
(1)\end{array}$ & & & & \\
\hline Q23 & \multicolumn{5}{|c|}{ Can you see or hear any livestock? } & \\
\hline
\end{tabular}




\begin{tabular}{|c|c|c|c|c|c|c|c|c|c|c|}
\hline & $\begin{array}{l}\text { None } \\
(0)\end{array}$ & \multicolumn{8}{|c|}{$\begin{array}{l}\text { Cows/Sheep/Horses } \\
\text { (1) }\end{array}$} & $\begin{array}{l}\text { Shared for Shar Planina, Wales and } \\
\text { Iceland }\end{array}$ \\
\hline \multirow[t]{2}{*}{ Q24 } & \multicolumn{9}{|c|}{$\begin{array}{l}\text { Can you see any traditional preserved houses, witness traditional } \\
\text { activity of any kind? }\end{array}$} & \multirow{2}{*}{$\begin{array}{l}\text { Shar Planina specific, in the case of } \\
\text { Wales and Iceland considered as } \\
\text { general assessment of presence of } \\
\text { buildings of architectural or cultural } \\
\text { interest or merit }\end{array}$} \\
\hline & $\begin{array}{l}\text { No } \\
(0)\end{array}$ & \multicolumn{8}{|c|}{ Yes } & \\
\hline \multirow[t]{2}{*}{ Q25 } & \multicolumn{9}{|c|}{$\begin{array}{l}\text { Can you see any buildings of merit/interest (important } \\
\text { buildings/objects)? }\end{array}$} & \multirow[t]{2}{*}{$\begin{array}{l}\text { Shared for Shar Planina, Wales and } \\
\text { Iceland }\end{array}$} \\
\hline & $\begin{array}{l}\text { No } \\
(0)\end{array}$ & \multicolumn{8}{|c|}{$\begin{array}{l}\text { Yes } \\
(1)\end{array}$} & \\
\hline \multicolumn{11}{|l|}{ SENSES } \\
\hline \multirow[t]{2}{*}{ Q26 } & \multicolumn{9}{|c|}{ Are there any strong/noticeable smells? } & \multirow{4}{*}{$\begin{array}{l}\text { Ephemeral aspects that might } \\
\text { influence personal landscape } \\
\text { appeal. Shared for Shar Planina and } \\
\text { Iceland }\end{array}$} \\
\hline & \multicolumn{9}{|l|}{ Free entry } & \\
\hline \multirow[t]{2}{*}{ Q27 } & \multicolumn{9}{|c|}{ Are there any noticeable/persistent sounds? } & \\
\hline & \multicolumn{9}{|l|}{ Free entry } & \\
\hline \multicolumn{11}{|l|}{ APPEAL } \\
\hline & Beautiful & 3 & 2 & 1 & 0 & -1 & -2 & -3 & Ugly & \multirow{5}{*}{$\begin{array}{l}\text { Personal landscape appeal ratings. } \\
\text { Shared for Shar Planina and Iceland }\end{array}$} \\
\hline & Natural & 3 & 2 & 1 & 0 & -1 & -2 & -3 & Managed & \\
\hline & Exciting & 3 & 2 & 1 & 0 & -1 & -2 & -3 & Dull & \\
\hline & Varied & 3 & 2 & 1 & 0 & -1 & -2 & -3 & Uniform & \\
\hline & Safe & 3 & 2 & 1 & 0 & -1 & -2 & -3 & Dangerous & \\
\hline Cloud cover & $<5 \%$ (clear) & \multicolumn{3}{|c|}{$\begin{array}{l}5-49 \% \\
\text { (partial } \\
\text { cloud) }\end{array}$} & \multicolumn{2}{|c|}{$\begin{array}{l}50-70 \% \\
\text { (cloudy) }\end{array}$} & & 71-1 & \% (overcast) & \multirow{3}{*}{$\begin{array}{l}\text { Other ephemeral aspects that might } \\
\text { influence personal landscape } \\
\text { appeal. Shared for Shar Planina and } \\
\text { Iceland }\end{array}$} \\
\hline Wind & Calm & & $\begin{array}{l}\text { ientle } \\
\text { reeze }\end{array}$ & & $\begin{aligned} \text { Moder } \\
\text { win }\end{aligned}$ & $\begin{array}{l}\text { ately } \\
\text { dy }\end{array}$ & & & Windy & \\
\hline Visibility & Clear & & Good & & Aver & age & & & Poor & \\
\hline \multicolumn{11}{|l|}{ Any notes } \\
\hline \multicolumn{11}{|c|}{ Camera photo $N^{\circ}$} \\
\hline Take photo & & & & & & & & & & \\
\hline
\end{tabular}




\section{S2: Detailed overview of component metrics and assessment specifics applied in the remote (GIS) visual quality assessment}

Component metrics marked in bold are added metrics to adapt the VQI index to capture the visual quality of Shar Planina. Component metrics marked with italic are adjusted metrics originally used in Swetnam et al. (2017) that due to study area specifics and/or spatial data availability assume different approach in metric assessment (descriptive and score).

\begin{tabular}{|c|c|c|c|c|}
\hline Theme & Component metric & $\begin{array}{c}\text { Metric } \\
\text { (descriptive) }\end{array}$ & $\begin{array}{l}\text { Metric } \\
\text { (score) }\end{array}$ & $\begin{array}{l}\text { Calculation specifics } \\
\text { (including evidence and supporting literature) }\end{array}$ \\
\hline \multirow{15}{*}{ 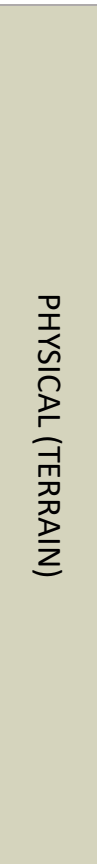 } & \multirow{7}{*}{$\begin{array}{l}\text { (T1) Terrain ruggedness } \\
\text { index }\end{array}$} & Level & 1 & \multirow{7}{*}{$\begin{array}{l}\text { Increase in terrain ruggedness is commonly associated with high visual quality within both physical (Otero Pastor et } \\
\text { al. 2007, Uzun and Muuml 2011, Vizzari 2011) and perceptual studies (Arriaza et al. 2004, Acar et al. 2006, Schirpke } \\
\text { et al. 2013). Mountains often associate with high visual appeal due to their scenic beauty (Nepal and Chipeniuk } \\
\text { 2005, Díaz et al. 2013, Petrova et al. 2015). } \\
\text { Assessed in accordance with Swetnam et al. (2017) using Riley et al. (1999). Calculated using } 30 \mathrm{~m} \text { resolution Digital } \\
\text { Elevation Model (ASTER GDEM) and calculated for each raster cell as the difference between square of the } \\
\text { maximum and minimum elevation values of the neighboring } 8 \text { cells. } \\
\text { The resulting dataset was then classified into } 7 \text { classes based on natural breaks in the dataset. }\end{array}$} \\
\hline & & Nearly level & 2 & \\
\hline & & Slightly rugged & 3 & \\
\hline & & $\begin{array}{l}\text { Intermediately } \\
\text { rugged }\end{array}$ & 4 & \\
\hline & & Moderately rugged & 5 & \\
\hline & & Highly rugged & 6 & \\
\hline & & Extremely rugged & 7 & \\
\hline & \multirow{8}{*}{$\begin{array}{l}\text { (T2) Rocky areas and } \\
\text { screes }\end{array}$} & None & 0 & \multirow{8}{*}{$\begin{array}{l}\text { Presence of rocks and rocky areas contributes to a higher visual quality rating, especially in mountainous regions. } \\
\text { The contribution levels with coverage, compactness and extent of rocky areas (Sari and Acar 2016). } \\
\text { In this regard, prominent rocky areas and screes marked visible on a 1:25000 map were digitised and assessed by } \\
\text { area coverage: }<10 \text { (1); } 10.01-20 \text { (2); } 20.01-50 \text { (3) and }>50 \text { (4). } \\
\text { In order to exclude rocks and rocky areas whose visibility was considered to be limited (due to small area coverage } \\
\text { and surrounding vegetation e.g. forest cover) the layer was subsequently intersected with Corine Land Cover (CLC) } \\
2018 \text { layer. All rocky sites that intersected with forest coverage (CLC classes } 311,312,313,324,242,243 \text { ) and had less } \\
\text { than } 10 \text { ha of coverage were assessed as } 0 \text { (all the polygons that intersected with more than one CLC class were re- } \\
\text { checked manually and the prevailing CLC class was selected as representative). } \\
\text { Considering that colour is effective in the physical perception of composition (Sari and Acar 2016), the layer was } \\
\text { then joined with background layer of geology and limestone rocks (massive limestone, marble, marbled white-gray } \\
\text { limestone and dolomites etc.) were graded as }+1 \text {. } \\
\text { The final assessment accounts for the highest observed grade within the } 1 \mathrm{~km}^{2} \text { survey square. }\end{array}$} \\
\hline & & $<10$ ha & 1 & \\
\hline & & $10.01-20$ ha & 2 & \\
\hline & & $20.01-50$ ha & 3 & \\
\hline & & $>50$ ha & 4 & \\
\hline & & \multirow[t]{3}{*}{$>50$ ha and limestone } & \multirow[t]{3}{*}{ C } & \\
\hline & & & & \\
\hline & & & & \\
\hline \multirow{6}{*}{ 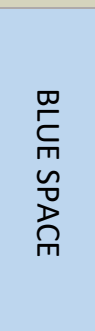 } & \multirow{6}{*}{$\begin{array}{l}\text { (BS1) Area of standing } \\
\text { water }\left(\mathrm{m}^{2}\right)\end{array}$} & None & 0 & \multirow{6}{*}{$\begin{array}{l}\text { The presence of water features is consistently associated with high landscape appeal (e.g. Arriaza et al. 2004, Acar et } \\
\text { al. 2006, Dramstad et al. 2006, Bulut and Karahan 2010, Schirpke et al. 2013) and the appeal increases with } \\
\text { increasing presence of water features and areas under water. } \\
\text { On Shar Planina, standing water is mostly presented in form of glacial lakes. Shar Planina is recognisable by presence } \\
\text { of numerous glacial lakes that have high scenic value that is further emphasised by the surrounding glacial cirques } \\
\text { and the accompanying rivulets and wetlands (Melovski et al. 2010). Larger areas with standing water that are } \\
\text { artificial in nature like Gradechko Ezero and Mavrovsko Ezero were also considered. } \\
\text { Assessed based on custom vector file of glacial lakes and water accumulations created with combined use of } \\
\text { 1:25000 map and Google Earth imagery. }\end{array}$} \\
\hline & & $>0-<1000$ & 1 & \\
\hline & & $\geq 1000-<2500$ & 2 & \\
\hline & & $\geq 2500-<5000$ & 3 & \\
\hline & & $\geq 5000-<10000$ & 4 & \\
\hline & & $\geq 10000$ & 5 & \\
\hline
\end{tabular}




\begin{tabular}{|c|c|c|c|c|}
\hline & & & & $\begin{array}{l}\text { Calculated as cumulative extent of standing water features within the } 1 \mathrm{~km}^{2} \text { survey square. } \\
\text { The classification was derived through examining the range of values present in the dataset. }\end{array}$ \\
\hline & \multirow{6}{*}{$\begin{array}{l}\text { (BS2) Length of flowing } \\
\text { water }(\mathrm{m})\end{array}$} & None & 0 & \multirow{6}{*}{$\begin{array}{l}\text { Assessed based on custom vector file of rivers and streams created based on 1:25000 map. } \\
\text { Calculated as the cumulative length }(\mathrm{m}) \text { of all rivers and streams within the } 1 \mathrm{~km}^{2} \text { survey square. } \\
\text { The classification was derived through examining the range of values present in the dataset. }\end{array}$} \\
\hline & & $>0-<500$ & 1 & \\
\hline & & $\geq 500-<1000$ & 2 & \\
\hline & & $\geq 1000-<2000$ & 3 & \\
\hline & & $\geq 2000-<3000$ & 4 & \\
\hline & & $\geq 3000$ & 5 & \\
\hline & \multirow{3}{*}{$\begin{array}{l}\text { (BS3) Presence of } \\
\text { waterfalls }\end{array}$} & Absent & 0 & \multirow{3}{*}{$\begin{array}{l}\text { Waterfalls are landscape features that are considered to have an universal appeal and are almost exclusively } \\
\text { associated with high visual quality (Hudson 2000, 2013, Bulut and Karahan 2010, Swetnam and Tweed 2018). The } \\
\text { specific fluvial relief of Shar Planina contributes to formation of numerous rapids, cascades and small waterfalls } \\
\text { along rivers and streams (Melovski et al. 2010). } \\
\text { Assessed based on custom vector file of waterfalls. } \\
\text { Calculated as the presence or absence of the feature in any part of the } 1 \mathrm{~km}^{2} \text { survey square. }\end{array}$} \\
\hline & & Present & 3 & \\
\hline & & & & \\
\hline & \multirow{2}{*}{$\begin{array}{l}\text { (BS4) Presence of } \\
\text { springs }\end{array}$} & Absent & 0 & \multirow{2}{*}{$\begin{array}{l}\text { On Shar Planina, presence of springs is often accompanied with diverse flowering vegetation associated with the } \\
\text { small wetlands that form in their surroundings. Presenting with drinking water supply in the mountain highlands, } \\
\text { springs are often used as a common resting place and are highly appreciated by the mountain shepherds and hikers. } \\
\text { Assessed based on custom vector file of springs. } \\
\text { Calculated as the presence or absence of the feature in any part of the } 1 \mathrm{~km}^{2} \text { survey square. }\end{array}$} \\
\hline & & Present & 1 & \\
\hline \multirow{13}{*}{ 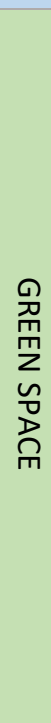 } & \multirow{6}{*}{$\begin{array}{l}\text { (GS1) Area of woodland } \\
(\%)\end{array}$} & None & 0 & \multirow{4}{*}{$\begin{array}{l}\text { Presence of woodlands is commonly associated with high landscape appeal (Dramstad et al. 2006, Otero Pastor et } \\
\text { al. 2007, Uzun and Muuml 2011, Schirpke et al. 2013) as it connects to number of visual concepts (Fry et al. 2009, } \\
\text { Norton et al. 2012) particularly naturalness, diversity, historicity and stewardship. Type of woodland also matters } \\
\text { (Otero Pastor et al. 2007, Schirpke et al. 2013, Tratalos et al. 2016). However, since all dominant forests types on } \\
\text { Shar Planina are natural this category metric considers the overall presence and coverage of forests while variances } \\
\text { in appeal of different forest types are captured as part of GS4. }\end{array}$} \\
\hline & & $<10$ & 1 & \\
\hline & & $\geq 10-<20$ & 2 & \\
\hline & & $\geq 20-<30$ & 3 & \\
\hline & & $\geq 30-<50$ & 4 & \multirow{2}{*}{$\begin{array}{l}\text { Assessed from custom land cover classification (Jovanovska 2019) based on Sentinel-2 (ESA 2019) high-resolution } \\
\text { imagery. Assessed with joint consideration to land cover classes of spruce-fir forests, beech forests and mixed } \\
\text { thermophilous forest. } \\
\text { Calculated as the area of woodland in each } 1 \mathrm{~km}^{2} \text { survey square, expressed as a \% of the total survey square area. }\end{array}$} \\
\hline & & $\geq 50$ & 5 & \\
\hline & \multirow{6}{*}{$\begin{array}{l}\text { (GS2) Area of natural } \\
\text { grasslands i.e. pastures } \\
\text { (\%) }\end{array}$} & None & 0 & \multirow{6}{*}{$\begin{array}{l}\text { Natural grasslands are associated to high landscape appeal within both physical (Otero Pastor et al. 2007, Uzun and } \\
\text { Muuml 2011) and perceptual studies (Lindemann-Matthies et al. 2010, Barroso et al. 2012, Frank et al. 2013, } \\
\text { Schirpke et al. 2013). Their main specifics, openness and preserved natural integrity, link to concepts of visual scale, } \\
\text { imageability and naturalness (Ode et al. 2008, Fry et al. 2009). Preferences for grasslands also link to concepts of } \\
\text { stewardship and historicity (Fry et al. 2009) especially with reference to extensively managed grasslands (Frank et al. } \\
2013 \text { ), but also extensively grazed natural grasslands (Lindemann-Matthies et al. 2010, Schirpke et al. 2013). } \\
\text { Assessed from custom land cover classification (Jovanovska 2019) based on Sentinel-2 (ESA 2019) high-resolution } \\
\text { imagery. Assessed with consideration to land cover classes of pastures and dry grasslands. } \\
\text { Calculated as the area of grassland in each } 1 \mathrm{~km}^{2} \text { survey square, expressed as a \% of the total survey square area. }\end{array}$} \\
\hline & & $<10 \%$ & 1 & \\
\hline & & $\geq 10-<20$ & 2 & \\
\hline & & $\geq 20-<30$ & 3 & \\
\hline & & $\geq 30-<50$ & 4 & \\
\hline & & $\geq 50$ & 5 & \\
\hline & & Absent & 0 & \\
\hline
\end{tabular}




\begin{tabular}{|c|c|c|c|}
\hline $\begin{array}{l}\text { (GS3) Presence of } \\
\text { wetlands }\end{array}$ & Present & 5 & $\begin{array}{l}\text { Wetlands provide visual contrast and diversity to the larger landscape (Ode et al. 2010, Ode and Miller 2011) and } \\
\text { associate with high vegetation diversity and common presence of birds, amphibians and invertebrates (Arias-García } \\
\text { et al. 2016). Even if visibility of water surface is low or water surface is absent, wetlands indicate presence of } \\
\text { waterways and are thus associated with higher landscape preference (Dramstad et al. 2006). } \\
\text { While wetlands of Shar Planina have low visibility of water surface or water surface is absent, their presence is } \\
\text { associated with high vegetation diversity, notable presence of flowering plants, but also high fauna diversity. In this } \\
\text { regard, the positive contribution of wetlands in the visual quality index is considered within the Green space theme. } \\
\text { Assessed based on custom vector file of wetlands. } \\
\text { Calculated as the presence or absence of the feature in any part of the } 1 \mathrm{~km}^{2} \text { survey square. }\end{array}$ \\
\hline \multirow{7}{*}{$\begin{array}{l}\text { (GS4) Habitat and plant } \\
\text { diversity }\end{array}$} & $\begin{array}{l}\text { Populated areas } \\
\text { Mineral extraction sites }\end{array}$ & 0 & \multirow{7}{*}{$\begin{array}{l}\text { Naturalness and vegetation diversity are both consistently associated with high visual quality throughout physical } \\
\text { (e.g. Gobster et al. 2007, Otero Pastor et al. 2007, Ferrari et al. 2008, Uzun and Muuml 2011) and perceptual studies } \\
\text { (e.g. Purcell and Lamb 1998, Acar et al. 2006, Rogge et al. 2007, Ode et al. 2009, van der Jagt et al. 2014). Diversity of } \\
\text { habitats and presence of heterogeneous vegetation links to concepts of diversity, coherence and complexity (Fry et } \\
\text { al. 2009) and are thus associated with positive landscape ratings (Dramstad et al. 2006, Lindemann-Matthies et al. } \\
\text { 2010, Schirpke et al. 2013, Häfner et al. 2018). } \\
\text { Assessed from custom land cover classification (Jovanovska 2019) based on Sentinel-2 (ESA 2019) high-resolution } \\
\text { imagery. Due to absence of spatial data on habitat and plant diversity, this metric has been calculated by assigning a } \\
\text { diversity rating to each land cover class (see Metric (descriptive) column to the left) based on expert input and } \\
\text { available literature data on habitat and species richness (Melovski et al. 2010). Finally, the overall habitat and plant } \\
\text { diversity was calculated as a sum of ratings assigned to individual land cover types within the } 1 \mathrm{~km}^{2} \text { survey square. }\end{array}$} \\
\hline & $\begin{array}{l}\text { Agricultural land - } \\
\text { cropland }\end{array}$ & 1 & \\
\hline & $\begin{array}{l}\text { Spruce-fir forests } \\
\text { Beech forests }\end{array}$ & 2 & \\
\hline & $\begin{array}{l}\text { Heterogeneous } \\
\text { agriculture - fields and } \\
\text { meadows }\end{array}$ & & \\
\hline & $\begin{array}{l}\text { Mixed thermophilous } \\
\text { forests } \\
\text { Transitional scrubland }\end{array}$ & 3 & \\
\hline & $\begin{array}{l}\text { Pastures } \\
\text { Lakes }\end{array}$ & 4 & \\
\hline & $\begin{array}{l}\text { Rocky areas and screes } \\
\text { Dry grasslands }\end{array}$ & 5 & \\
\hline \multirow[t]{3}{*}{$\begin{array}{l}\text { (GS5) Type of } \\
\text { agriculture and } \\
\text { hedgerow arrangement }\end{array}$} & Linear scarce & 1 & $\begin{array}{l}\text { The history and tradition of different agricultural land management practices is reflected in the appearance of } \\
\text { agricultural and rural landscapes, mainly through composition and arrangement of fields and hedges (Melovski et al. } \\
\text { 2019). } \\
\text { With reference to visual quality assessment, composition and arrangement of fields and hedges link to concepts of } \\
\text { coherence, complexity, visual scale, stewardship and historicity (Tveit et al. 2006, Fry et al. 2009). Diverse and } \\
\text { extensively managed agricultural landscapes with structured woodlands and hedges are often associated with high } \\
\text { landscape appeal (Dramstad et al. 2006, Rogge et al. 2007, Lindemann-Matthies et al. 2010, Frank et al. 2013, } \\
\text { Häfner et al. 2018). }\end{array}$ \\
\hline & Tidy Thermophilous & 2 & \multirow[b]{2}{*}{$\begin{array}{l}\text { Due to absence of detailed spatial data on composition and arrangement of fields and hedges on Shar Planina, this } \\
\text { metric has been assessed with consideration of the specifics of corresponding land cover classes: } \\
\text { - Agricultural land-cropland: includes medium-scale fields and acres of crops that are more intensively managed. } \\
\text { Hedges are sparse and mostly linear and mainly represented by fruit trees and other anthropogenic broad-leaved } \\
\text { trees. Other linear hedge-like elements include narrow corridors of riparian forests and fragmented stripes of } \\
\text { natural forest vegetation. } \\
\text { - Heterogeneous agriculture - fields and meadows: characterised by higher degree of naturalness, this land cover } \\
\text { type includes large number of small-scale fields arranged in a mosaic (small land parcels with different cultivation } \\
\text { types) and large number of extensively managed meadows. Within, thicker lines of hedges of fruit trees and/or } \\
\text { remnants of natural forest vegetation take a mesh-like form and their appearance 'tidy' or 'veneering' is defined by } \\
\text { type and intensity of land use practices and the concurrent process of abandonment. }\end{array}$} \\
\hline & $\begin{array}{l}\text { "Veneering" } \\
\text { Thermophilous }\end{array}$ & 3 & \\
\hline
\end{tabular}




\begin{tabular}{|c|c|c|c|c|}
\hline & & Tidy Mesophillous & 4 & $\begin{array}{l}\text { Assessed from custom land cover classification (Jovanovska 2019) based on Sentinel-2 (ESA 2019) high-resolution } \\
\text { imagery. } \\
\text { Calculated by intersecting the land cover classes of heterogeneous agriculture - fields and meadows and agricultural } \\
\text { land-cropland with corresponding agricultural and rural landscape types (Melovski et al. 2019) as follows: } \\
\rightarrow \text { Linear scarce = agricultural land-cropland } \\
\rightarrow \text { Tidy thermophilous = heterogeneous agriculture }- \text { fields and meadows \& flatland sub-continental agricultural- } \\
\text { rural landscape + rolling rural landscape with hedges + hilly rural landscape } \\
\rightarrow \text { "Veneering" thermophilous = heterogeneous agriculture - fields and meadows \& hilly rural landscape (Tetovo } \\
\text { area) } \\
\rightarrow \text { Tidy mesophillous = heterogeneous agriculture }- \text { fields and meadows \& mountain rural landscapes } \\
\text { Calculated as prevailing hedgerow type within the } 1 \mathrm{~km}^{2} \text { survey square. }\end{array}$ \\
\hline & & None & 5 & $\begin{array}{l}\text { In order to level the absence of this metric with reference to natural landscapes and considering the strong positive } \\
\text { correlation between preference and naturalness (Purcell and Lamb 1998, Arriaza et al. 2004, Fry et al. 2009, van der } \\
\text { Jagt et al. 2014) survey squares with no agricultural land receive highest score. }\end{array}$ \\
\hline \multirow{16}{*}{ 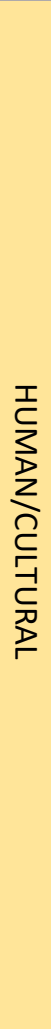 } & \multirow{7}{*}{$\begin{array}{l}\text { (H1) Area of human- } \\
\text { influenced habitats (\%) }\end{array}$} & $\geq 50$ & 0 & \multirow{7}{*}{$\begin{array}{l}\text { Increased presence of constructed/artificial habitats and infrastructure links to the concept of disturbance (Ode et } \\
\text { al. 2008, Fry et al. 2009) and is often assessed to have a negative impact on landscape quality within both physical } \\
\text { (Gulinck et al. 2001, e.g. Otero Pastor et al. 2007, Uzun and Muuml 2011, Swetnam et al. 2017) and perceptual } \\
\text { studies (Acar et al. 2006, Kaplan et al. 2006, Howley 2011, van der Jagt et al. 2014). } \\
\text { Assessed from custom land cover classification (Jovanovska 2019) based on Sentinel-2 (ESA 2019) high-resolution } \\
\text { imagery with consideration to land cover classes of populated areas and mineral extraction sites. } \\
\text { Calculated as the area of human influenced habitats in each } 1 \mathrm{~km}^{2} \text { survey square, expressed as \% of the total survey } \\
\text { square area. }\end{array}$} \\
\hline & & $\geq 40-<50$ & 1 & \\
\hline & & $\geq 30-<40$ & 2 & \\
\hline & & $\geq 20-<30$ & 3 & \\
\hline & & $\geq 10-<20$ & 4 & \\
\hline & & $\geq 0.1-<10$ & 5 & \\
\hline & & $<0.1$ & 10 & \\
\hline & \multirow{2}{*}{$\begin{array}{l}\text { (H2) Utilities and } \\
\text { destruction ( } n \text { ) }\end{array}$} & Absent & 5 & \multirow[b]{2}{*}{$\begin{array}{l}\text { Landscape quality is perceived to decline as presence of linear utilitarian infrastructure (electricity pylons, wind } \\
\text { turbines, masts, pipelines etc.) increases (Kaplan et al. 2006, Molnarova et al. 2012, Devine-Wright and Batel 2013). } \\
\text { Assessed based on custom vector file of built infrastructure that is dispersed and utilitarian (electricity pylons, } \\
\text { hydropower plants, including the structures of "HES" Mavrovo i.e. the hydropower system and the complementing } \\
\text { catchment system of channels "Sharski Vodi" that fill the hydro accumulation "Mavrovo Lake" located in the slopes } \\
\text { of Shar Planina on its bordering line with mountain Bistra. } \\
\text { Calculated as the presence or absence of the feature in any part of the } 1 \mathrm{~km}^{2} \text { survey square. }\end{array}$} \\
\hline & & Present & 0 & \\
\hline & \multirow{5}{*}{$\begin{array}{l}(\mathrm{H} 3) \text { Total length of } \\
\text { roads }(\mathrm{m})\end{array}$} & $>5000$ & 0 & \multirow{5}{*}{$\begin{array}{l}\text { Although presence of roads generally results in lower landscape appreciation, the negative influence of roads levels } \\
\text { depending on the road type (Garré et al. 2009) and small unpaved roads rate highly than asphalt roads. } \\
\text { Assessed based on custom vector file of roads created based on 1:25000 map and Google Earth imagery. } \\
\text { Calculated as cumulative length of roads in each } 1 \mathrm{~km}^{2} \text { survey square. }\end{array}$} \\
\hline & & $\geq 3000-<5000$ & 1 & \\
\hline & & $\geq 1000-<3000$ & 2 & \\
\hline & & $>0-<1000$ & 3 & \\
\hline & & 0 & 4 & \\
\hline & \multirow[t]{2}{*}{ (H4) Type of roads } & Asphalt road & 0 & \multirow{2}{*}{$\begin{array}{l}\text { Assessed based on custom vector file of roads created based on 1:25000 map and Google Earth imagery. } \\
\text { Calculated by rating the individual road types (see Metric (descriptive) column to the left) in each } 1 \mathrm{~km}^{2} \text { survey } \\
\text { square. The final assessment accounts for the lowest observed grade within the } 1 \mathrm{~km}^{2} \text { survey square. }\end{array}$} \\
\hline & & $\begin{array}{l}\text { Local/village asphalt } \\
\text { road }\end{array}$ & 1 & \\
\hline
\end{tabular}




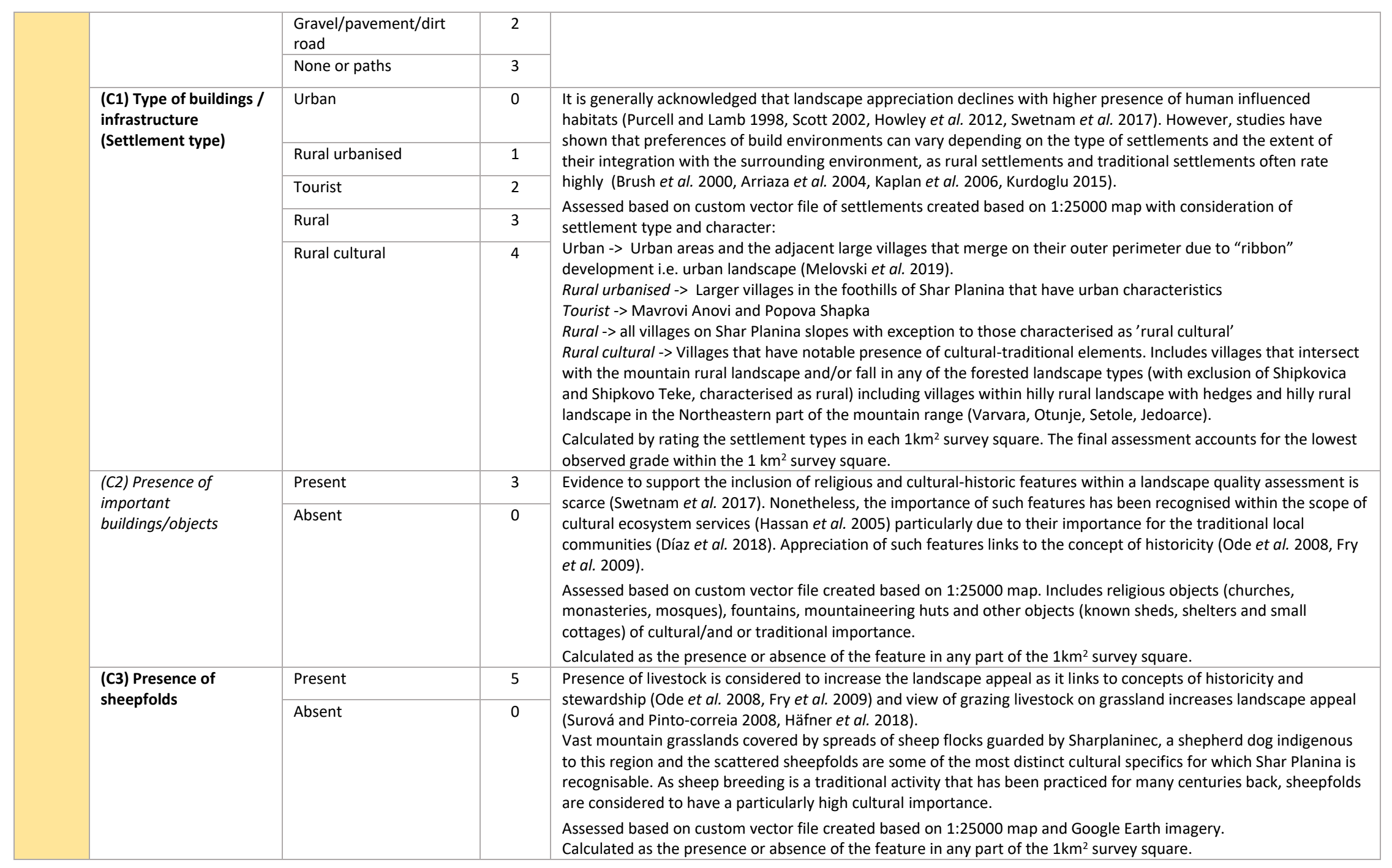




\section{S3: VQI calculation approach and theme weighting sensitivity analysis}

The VQI and theme weighting sensitivity have been assessed in accordance with calculation specifics presented in Swetnam et al. (2017) and Swetnam and Tweed (2018). Within its quantitative/biophysical assessment, the final VQI score is calculated as a weighted sum of four contributing themes: Physical, Blue space, Green Space and Human/Cultural (Swetnam et al. 2017; Swetnam and Tweed 2018). To confirm that this approach of combining Human and Historic/Cultural themes together does not have an adverse effect, the VQI for Shar Planina was also calculated with consideration of all five themes as originally presented in Swetnam et al. (2017). While the final output of the VQI calculated as a product of five themes strongly correlates with the final output of the VQI calculated as a product of four themes ( $r=0.97$ in case of field-based VQI assessment and 0.99 in the case of remote VQI assessment), the latter demonstrates stronger correlation $(r=0.72)$ to the qualitative assessment results (appeal).

The number of parameters assessed within each of the four themes in field visual quality assessment (S1) and GIS visual quality assessment (S2) is different. In the case of field visual quality assessment the Physical and the Blue space themes each contribute by only $12 \%$ in comparison to Green space (48\%) and Human/Cultural (29\%). In the case of GIS visual quality assessment the Physical theme contributes by only $12 \%$ followed by Blue space $(15 \%)$ in comparison to Green space (37\%) and Human/Cultural (36\%).

In order to equate the contribution of each of the four themes the values from each theme are first scaled to a value between 0 and 1 (see equation 1 ) and then the four themes are weighted in their contribution to the final VQI (note that the participation of each theme in determining the final VQI still varies depending on its presence and appearance within assessed landscape view).

Due to the mountainous character of Shar Planina and its high naturalness, we consider that the two themes Physical and Green space have a higher contribution in the overall visual appeal (both in terms of presence and importance) than the themes Blue space and Human/Cultural. With further consideration of supporting literature on the importance of topography and visual scale (Acar et al. 2006, Ode et al. 2008, Sang et al. 2008, Tveit 2009) and naturalness and vegetation (e.g. Rogge et al. 2007, Ferrari et al. 2008, Ode et al. 2009, Frank et al. 2013) in landscape visual appeal, for the purpose of this study, the four themes have been assigned unequal weights: Physical (0.3), Blue space (0.2), Green space (0.3) and Human/Cultural (0.2). The final VQI is a sum of the products of scaled value within each theme and theme weighting (see equation 2 ).

1) $s=x \div \max$

2) $V Q I=(P(s) * 0.3)+(B S(s) * 0.2)+(G S(s) * 0.3)+(H C(s) * 0.2)$

$s:$ Scaled value within each theme ${ }^{1}$

$x$ : Sum of assigned values within each theme (by the observer or calculated value within $\mathrm{x} \mathrm{km}^{2}$ survey square) $\max$ : Maximum value of each theme

\footnotetext{
${ }^{1}$ Considering that on Shar Planina landscapes range from agricultural to rural and highly natural when scaling the Green space theme in the case of field VQI calculation, agricultural and rural landscapes were scaled differently to forest landscapes, mountain grassland landscapes and mountain rocky landscapes. Meaning, if the answer to the question Q14 to Q17 was no (see S1), then the Green space theme was scaled by 16 (maximum value of theme if agricultural areas were absent) instead of 25 (maximum value of theme if agricultural areas were present). By adjusting the scaling of the Green space theme when calculating the VQI in field visual quality assessments, we avoid decrease in value of typical natural landscapes views due to absence of elements that are not representative and are not expected to be seen by the observer. In the case of GIS visual quality assessment this was levelled by applying highest rating to natural landscapes within GS4 and GS5 (see S2).
} 
Physical (P); Blue space (BS); Green space (GS); Human/Cultural $(H C)$

A sensitivity analysis was performed in order to assess the impact of different weight factors on the final value of the VQI. The sensitivity analysis was carried with reference to each theme by increasing the weight factor in increments of $10 \%$ with the remaining weights then spread equally between the other three themes (for calculation specifics see Swetnam et al. (2017) and Swetnam and Tweed (2018)). The VQI was then re-calculated for each site with respect to both field and GIS visual quality assessments. The effect of changing weighting on overall VQI (10\% increments) are presented as min, median and max on Figure S3-1 and Figure S3-2.

In case of Shar Planina, the VQI is highly impacted if any of the themes is either removed or increased to a weighting of over $60 \%$. In the case of field visual quality assessment the Green space theme is most stable (Figure S3-1) and can stand weightings that range up to 0.6, followed by Human/Cultural that stays stable if weighted up to 0.5 (this theme is stable considering it is a merger of human/built and historic/cultural elements, combined due to the unequal distribution of historic/cultural elements in the study area and lack of detailed spatial data). The Physical theme also stays stable if weighted to 0.4 . Increasing the weightings of Blue space theme above 0.3 has highest impact and it adversely affects the representation of other themes.

In the case of GIS visual quality assessment, when weighting is applied, all themes with exception to Blue space show very high stability (Figure S3-2). Green space theme is most stable, followed by Human/Cultural and Terrain. Again, increasing the weightings of Blue space theme above 0.3 has highest impact and it adversely affects the representation of other themes.

Overall, when participation of all four themes is considered, the VQI remains stable when changes to individual class weights remain in the range between 0.1 and 0.4 .

Figure S3-1 Overview of the effect of changing weighting on overall VQI (10\% increments) in field quality assessment
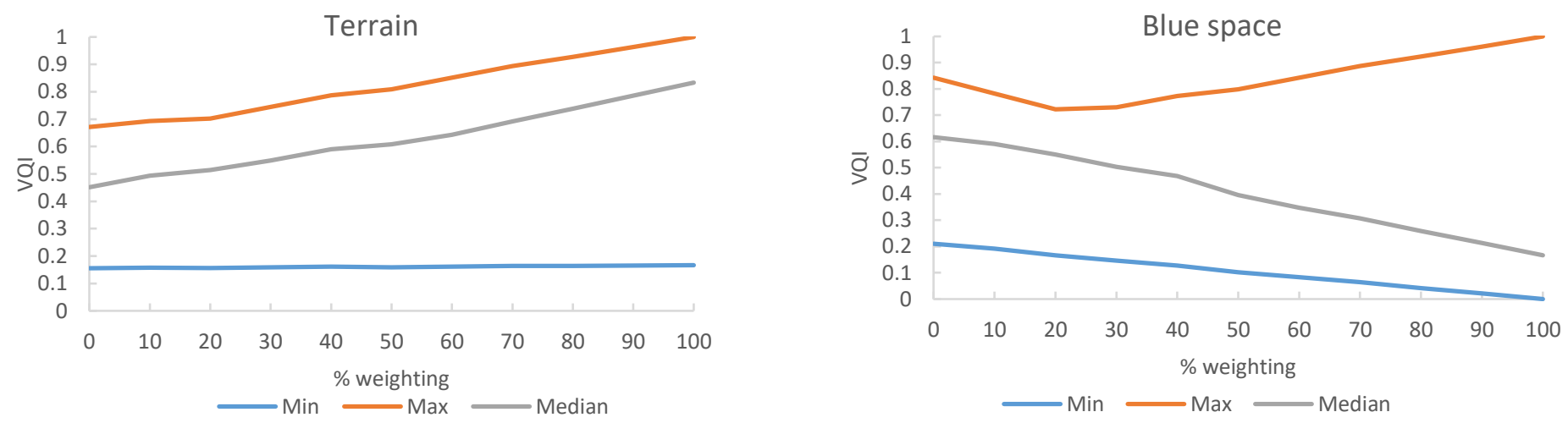

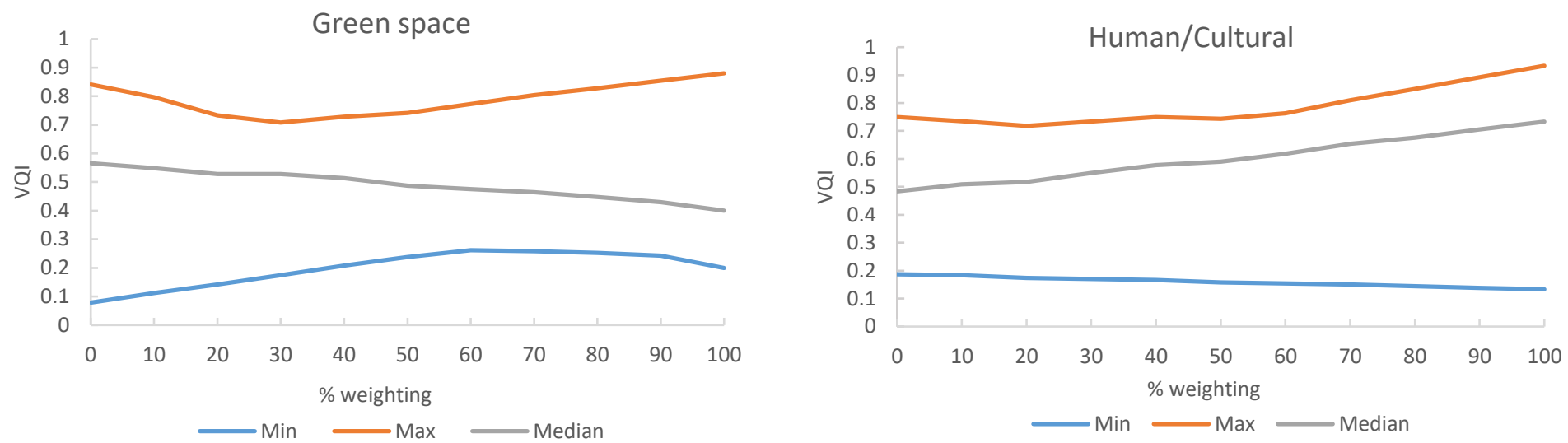

Figure S3-2 Overview of the effect of changing weighting on overall VQI ( $10 \%$ increments) in GIS quality assessment
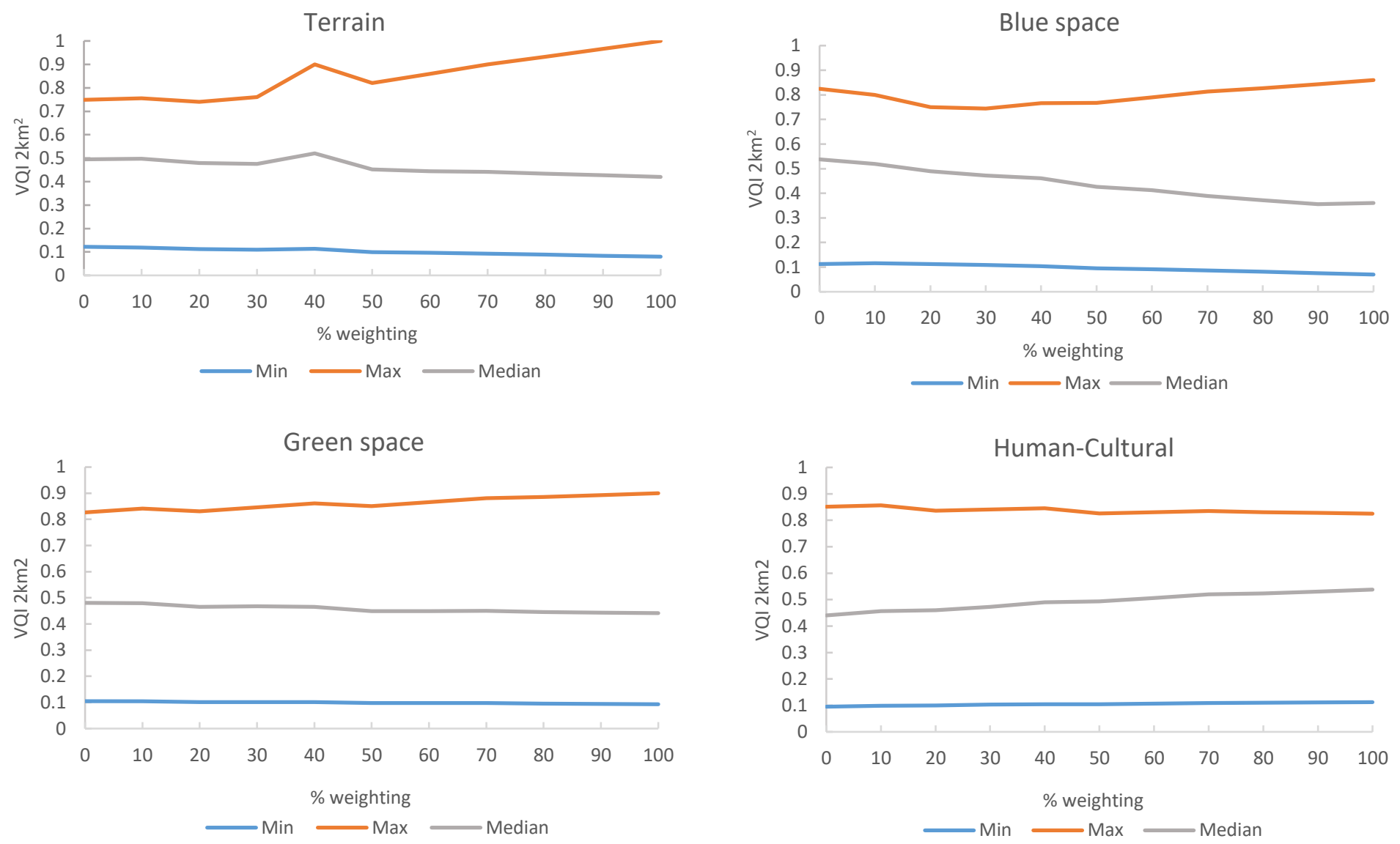


\section{S4: VQI field evaluation examples of landscape views assessed by more than one participant and associated personal responses for visual}

appeal including comparative presentation of corresponding remote (GIS) VQI scores

VQI scores from both field and GIS $\left(2 \mathrm{~km}^{2}\right)$ visual quality assessments are included. To capture the variations in individual field visual quality assessments, VQI scores for landscape views assessed by more than one participant are also included (line one in figure description). The overall appeal score (indicated in brackets) has a theoretical maximum of +15 (all individual appeal categories are rated as +3 ) and a theoretical minimum of -15 (all individual appeal categories are rated as -3 , see S1). To capture the contribution of each of the themes within the final VQI score in the case of GIS visual quality assessment (line two in figure description), individual scores (scaled to 1) for each of the four themes are included: Physical/Terrain (T), Blue space (BS), Green space (GS), Human/Cultural (H/C).

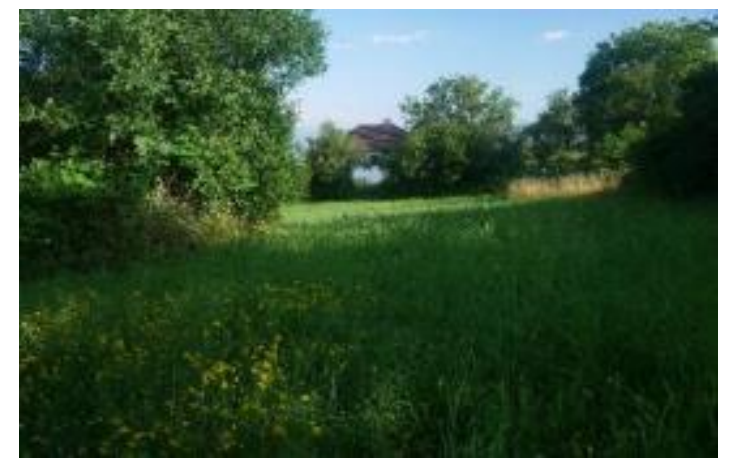

VQI: 0.36 (1); 0.38 (4); $0.40(-1)$

VQI $2 \mathrm{~km}^{2}: 0.27$ | (T) 0.17 (BS) 0.29 (GS) $0.40(\mathrm{H} / \mathrm{C}) 0.24$

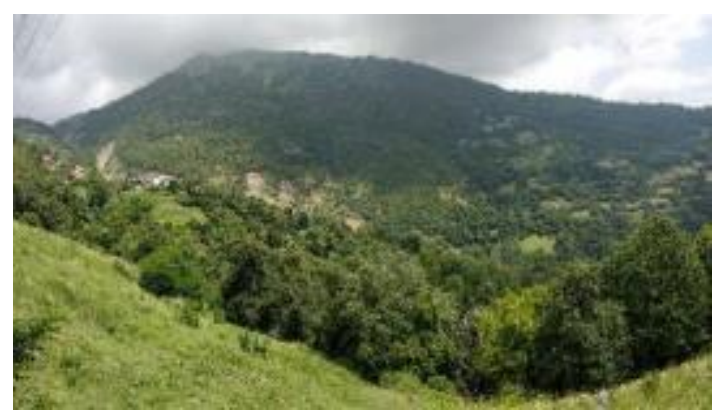

VQI: 0.54 (6); 0.54 (7)

VQI 2km²: 0.46 | (T) 0.33 (BS) 0.21 (GS) 0.69 (H/C) 0.56

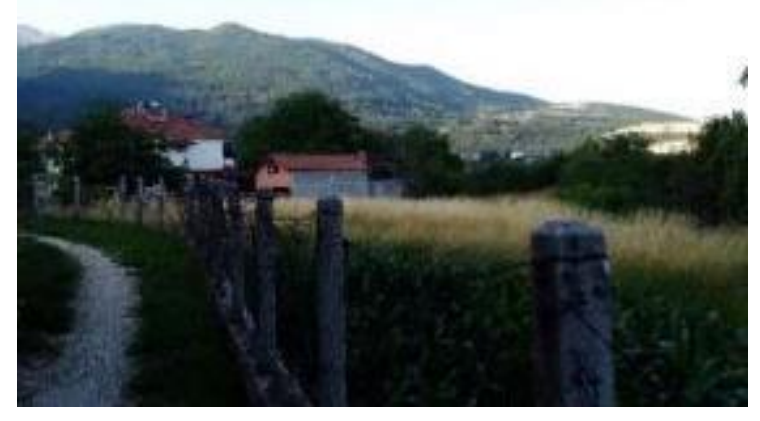

VQI: 0.40 (-2); 0.51 (4); $0.51(-2)$

VQI $2 \mathrm{~km}^{2}: 0.42$ | (T) 0.25 (BS) 0.36 (GS) 0.57 (H/C) 0.5

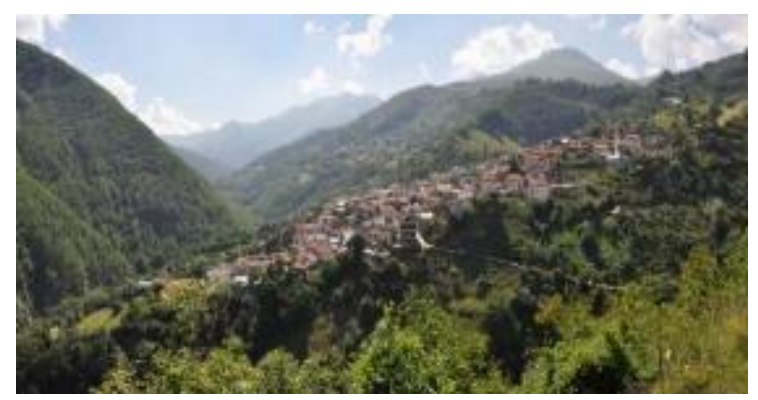

VQI: 0.56 (6); $0.63(10)$

VQI $2 \mathrm{~km}^{2}: 0.53$ | (T) 0.67 (BS) 0.29 (GS) 0.69 (H/C) 0.35

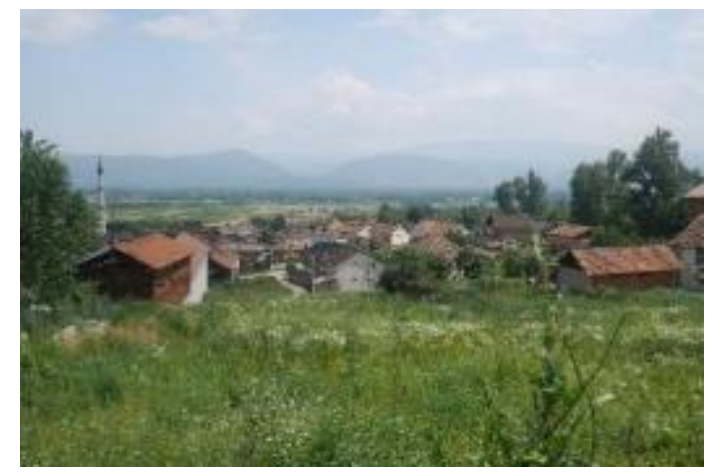

VQI: $0.38(-4) ; 0.35(1) ; 0.35(-2)$

VQI $2 \mathrm{~km}^{2}: 0.36$ | (T) 0.25 (BS) 0.36 (GS) 0.43 (H/C) 0.44

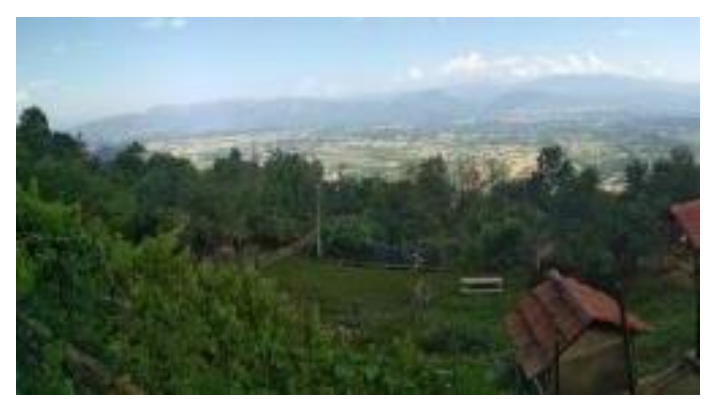

VQI: 0.53 (8); $0.44(5) ; 0.45$ (6)

VQI $2 \mathrm{~km}^{2}: 0.36$ | (T) 0.25 (BS) 0.36 (GS) $0.43(\mathrm{H} / \mathrm{C}) 0.44$ 


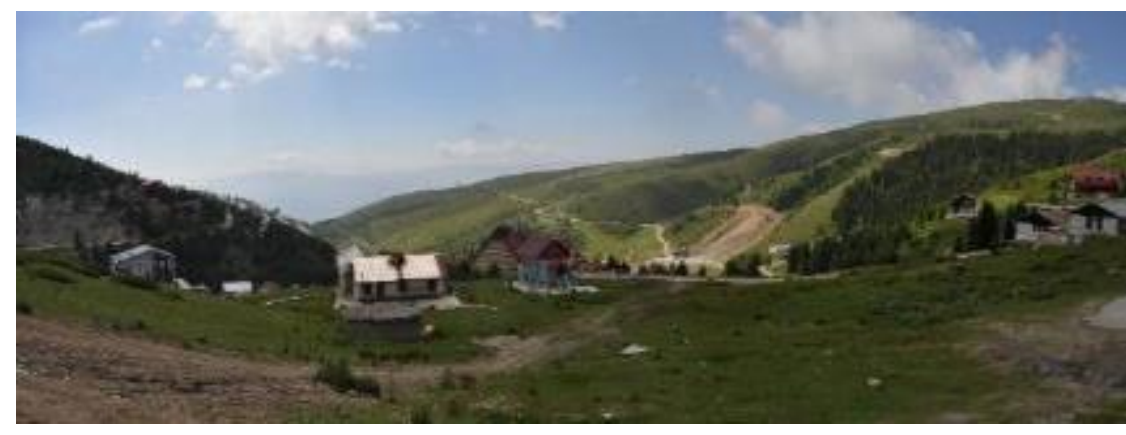

VQI: $0.35(-2) ; 0.48(3) ; 0.55(-1)$

VQI 2km²: 0.49 | (T) 0.50 (BS) 0.43 (GS) 0.74 (H/C) 0.18

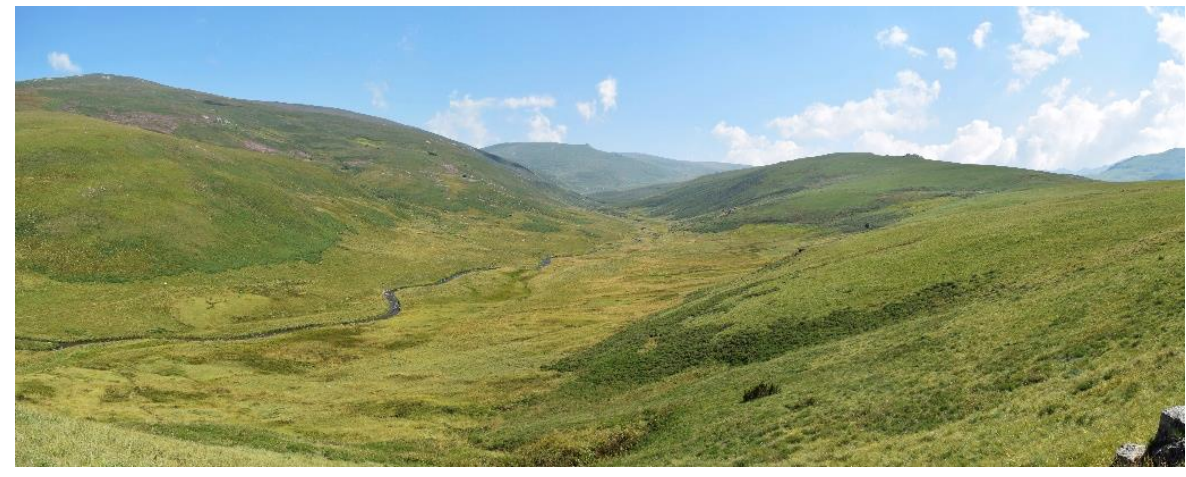

VQI: 0.54 (12); 0.47 (10)

VQI 2km²: 0.50 | (T) 0.25 (BS) 0.36 (GS) 0.80 (H/C) 0.56

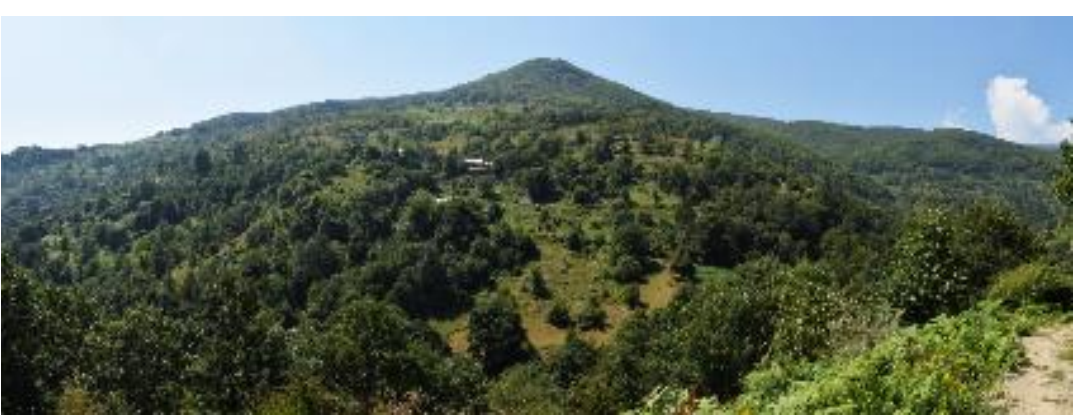

VQI: 0.49 (8); 0.5 (7)

VQI 2km²: 0.56 | (T) 0.58 (BS) 0.43 (GS) 0.69 (H/C) 0.47

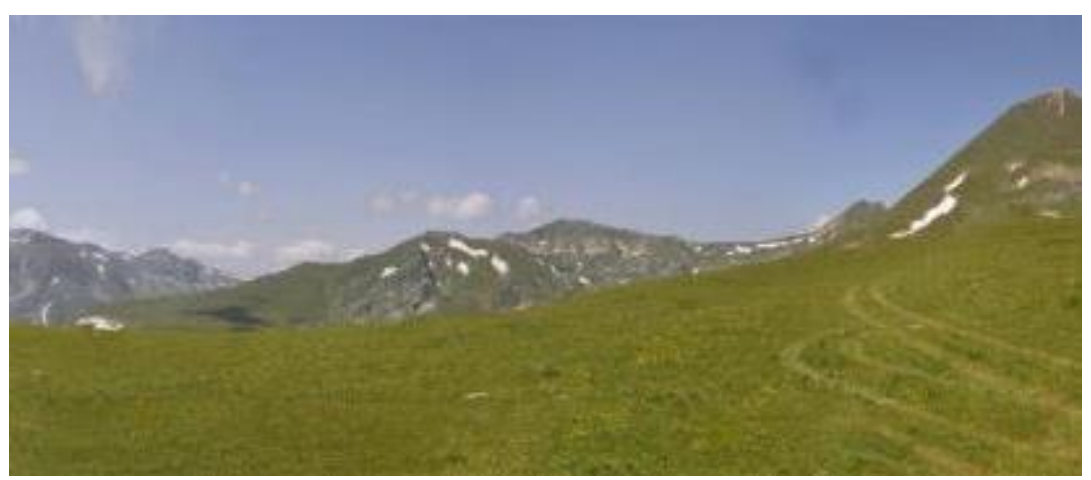

VQI: 0.57 (12); 0.61 (12); 0.63 (12)

VQI 2km²: 0.58 | (T) 0.58 (BS) 0.36 (GS) 0.63 (H/C) 0.71 


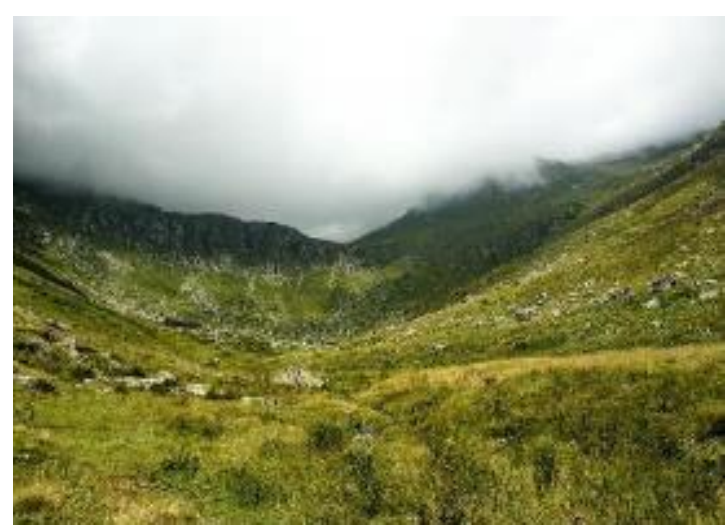

VQI: 0.65 (11); 0.66 (8)

VQI 2km²: 0.68 | (T) 0.75 (BS) 0.36 (GS) 0.86 (H/C) 0.65

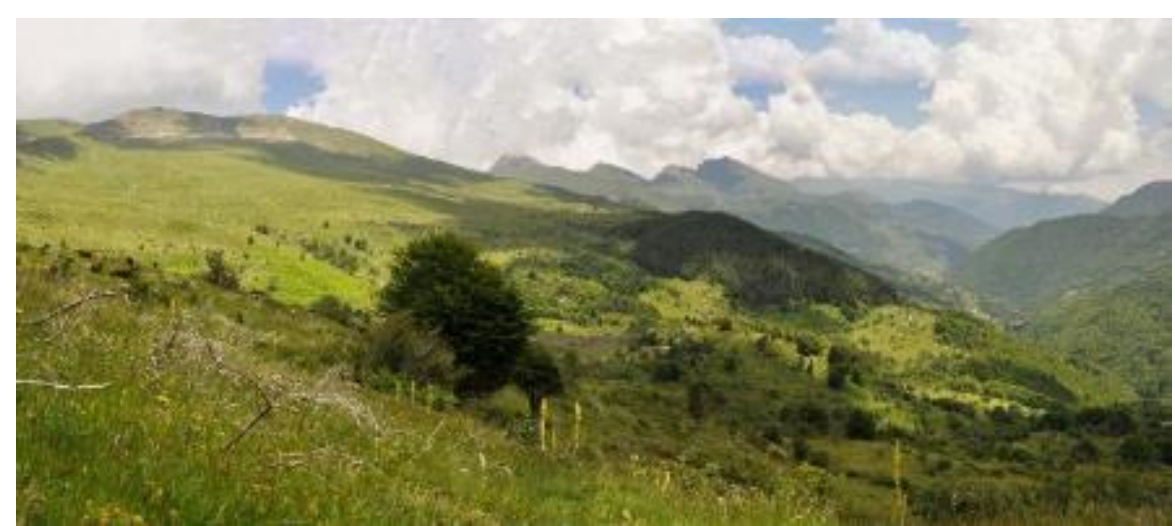

VQI: 0.73 (9); 0.62 (10); 0.60 (9)

VQI 2km²: 0.57 | (T) 0.50 (BS) 0.43 (GS) 0.63 (H/C) 0.71

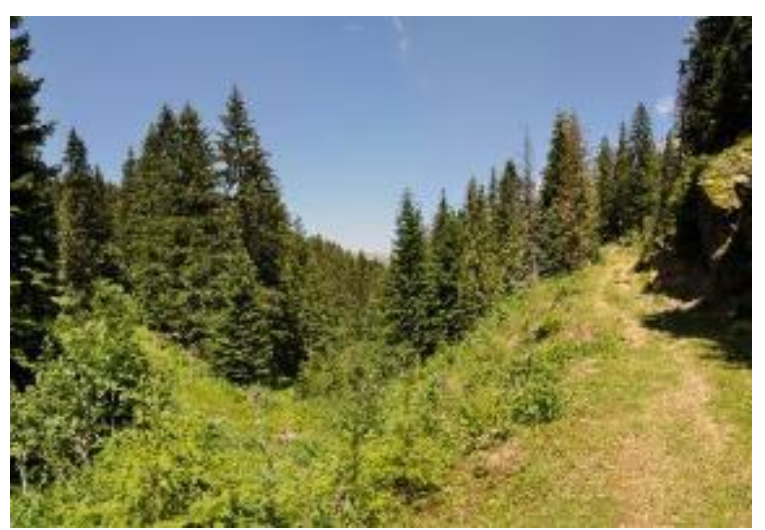

VQI: 0.58 (13); 0.68 (8)

VQI 2km²: 0.56 | (T) 0.67 (BS) 0.36 (GS) 0.71 (H/C) 0.38

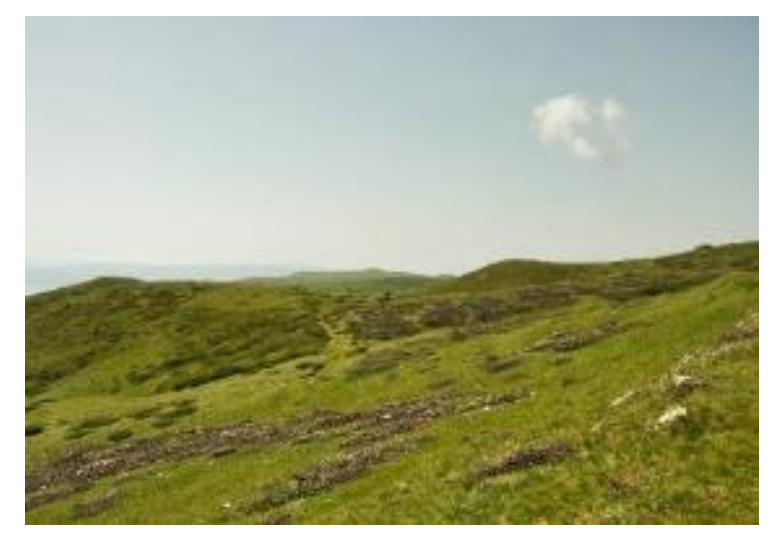

VQI: 0.38 (8); 0.38 (8); 0.55 (0)

VQI $2 \mathrm{~km}^{2}: 0.62$ | (T) 0.67 (BS) 0.43 (GS) 0.74 (H/C) 0.56

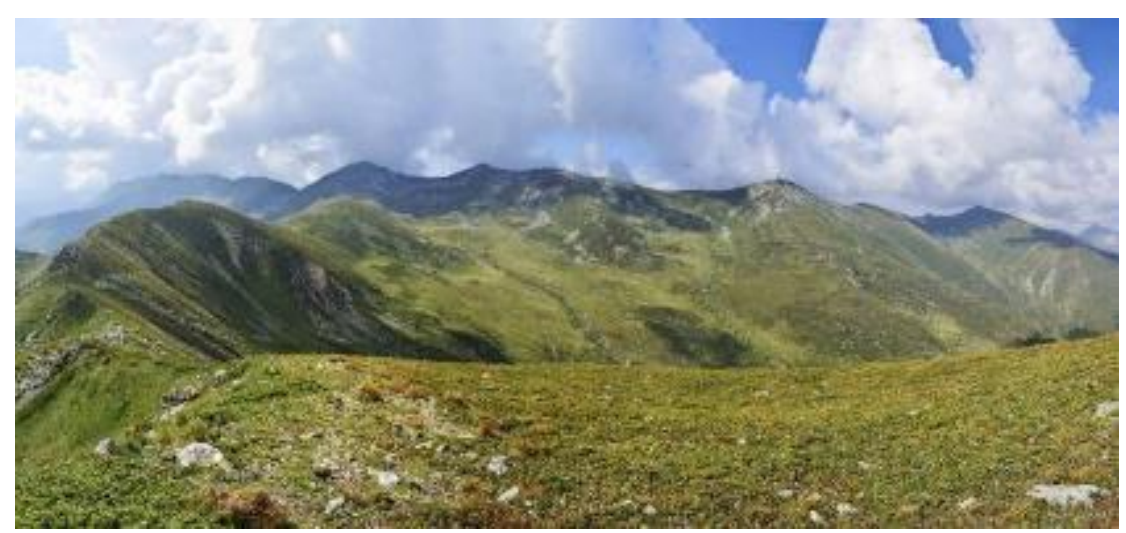

VQI: 0.66 (13); 0.66 (12)

VQI 2km²: 0.57 | (T) 0.58 (BS) 0.21 (GS) 0.74 (H/C) 0.65 


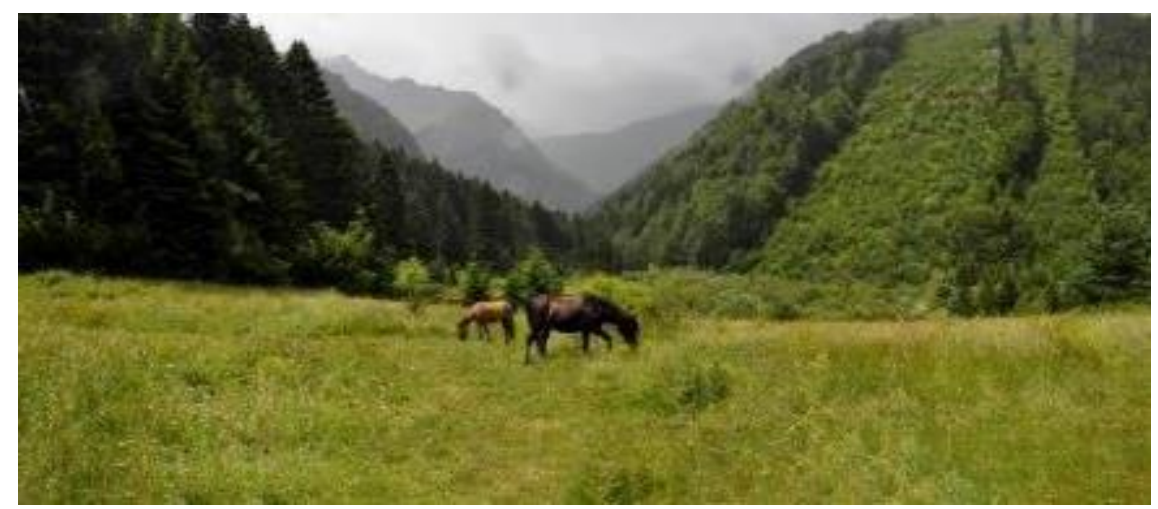

VQI: 0.64 (11); 0.61 (14)

VQI 2km²: 0.72 | (T) 0.92 (BS) 0.50 (GS) 0.71 (H/C) 0.65

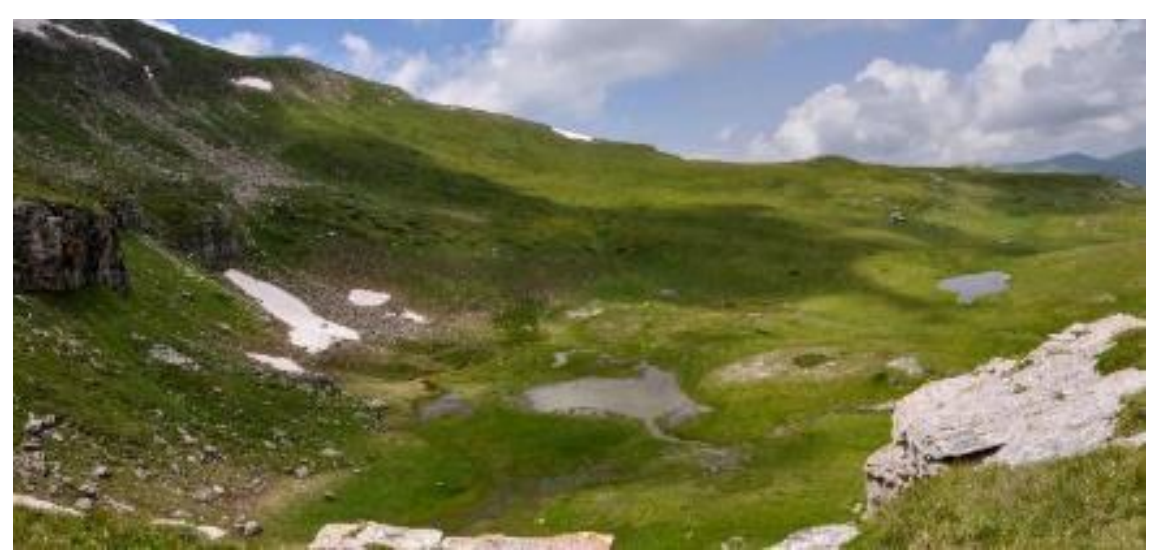

VQI: 0.66 (12); 0.66 (12); 0.66 (12)

VQI 2km²: 0.67 | (T) 0.75 (BS) 0.43 (GS) 0.77 (H/C) 0.65

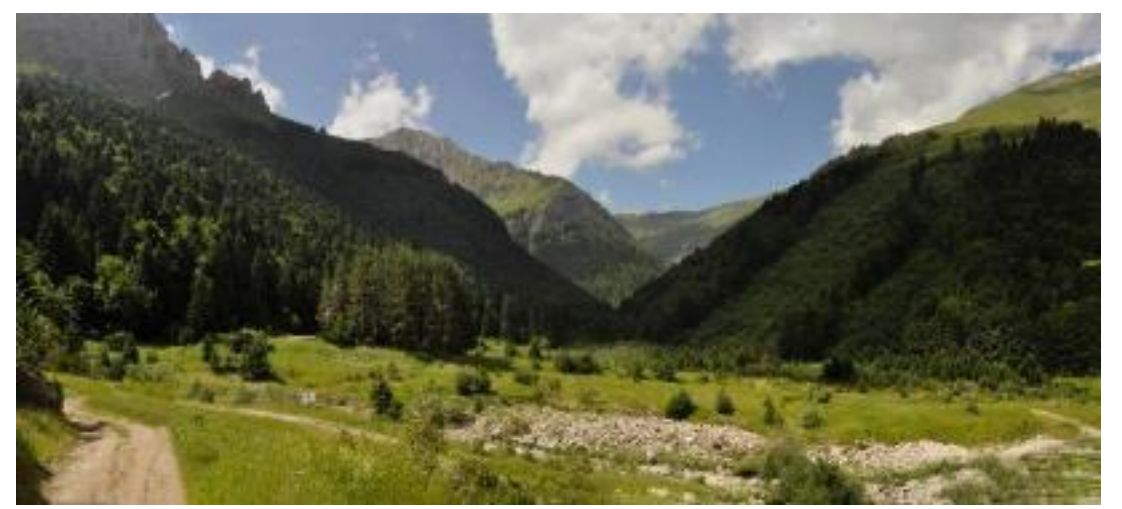

VQI: 0.74 (13); 0.74 (13); 0.74 (13)

VQI $2 \mathrm{~km}^{2}: 0.72$ | (T) 0.92 (BS) 0.50 (GS) 0.71 (H/C) 0.65

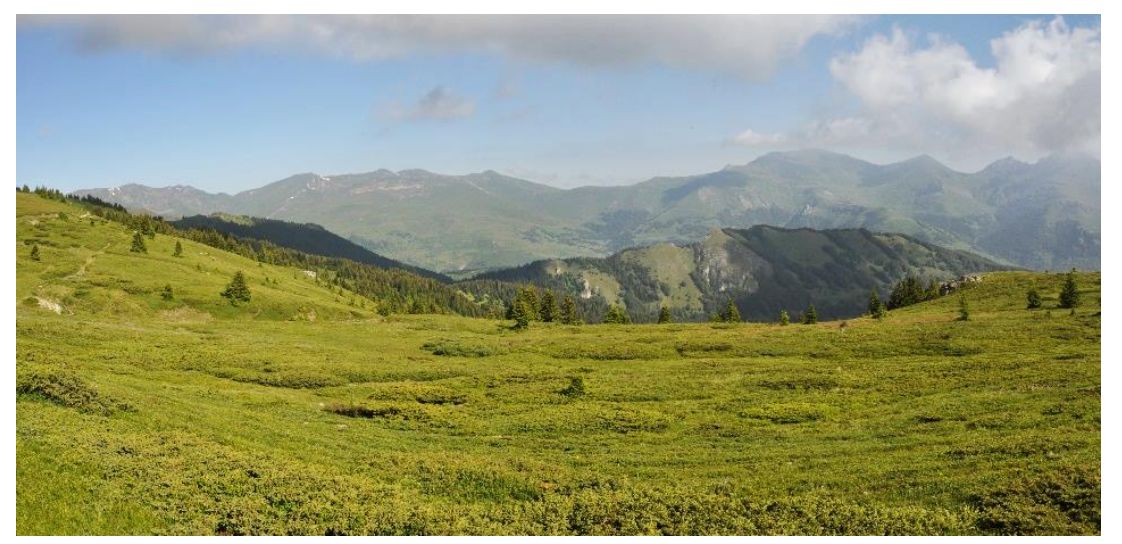

VQI: 0.73 (11); 0.73 (11); 0.73 (11)

VQI $2 \mathrm{~km}^{2}: 0.60$ | (T) 0.83 (BS) 0.36 (GS) 0.74 (H/C) 0.29 


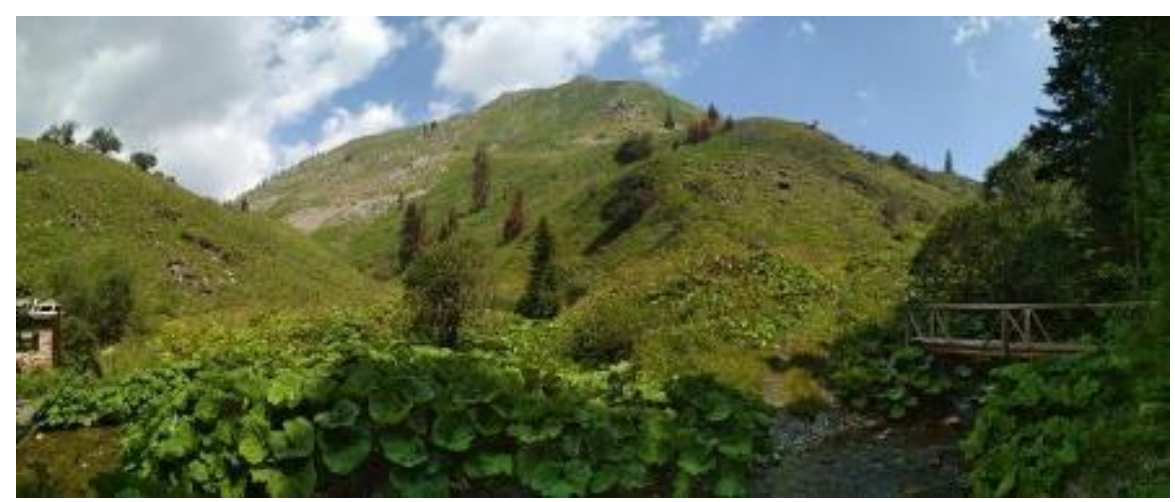

VQI: 0.70 (14); 0.62 (9)

VQI 2km²: 0.63 | (T) 0.83 (BS) 0.36 (GS) 0.74 (H/C) 0.44

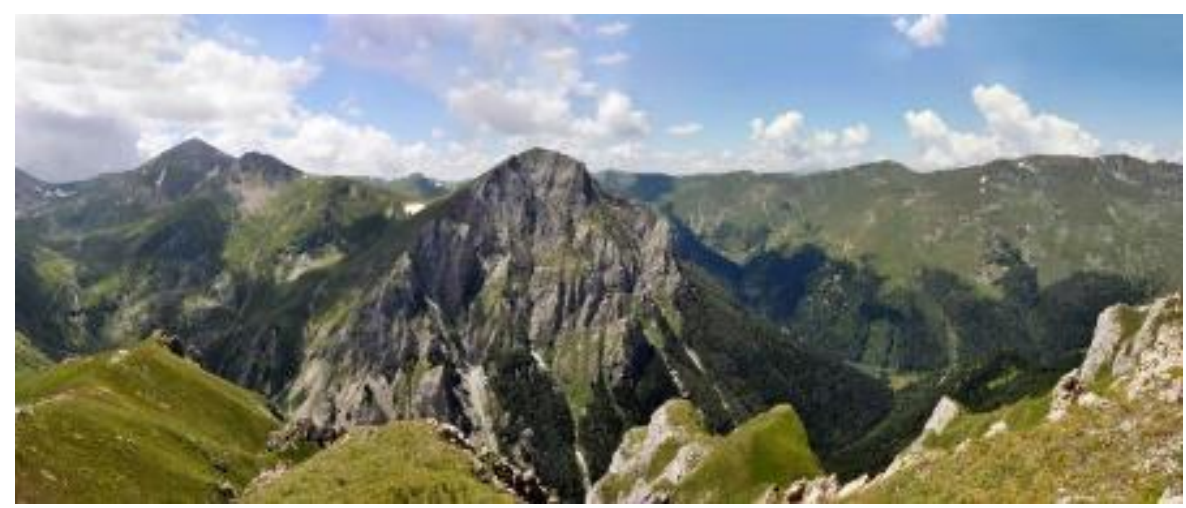

VQI: 0.82 (10); 0.72 (10); 0.75 (9)

VQI 2km²: 0.74 | (T) 0.92 (BS) 0.36 (GS) 0.83 (H/C) 0.74

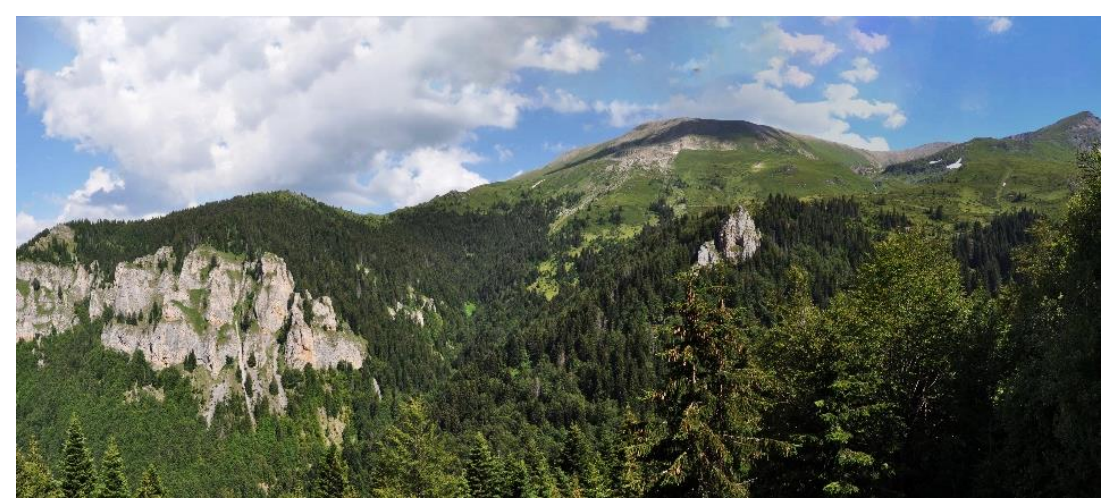

VQI: 0.71 (9); 0.69 (8); 0.65 (7)

VQI 2km²: 0.63 | (T) 0.83 (BS) 0.29 (GS) 0.71 (H/C) 0.56

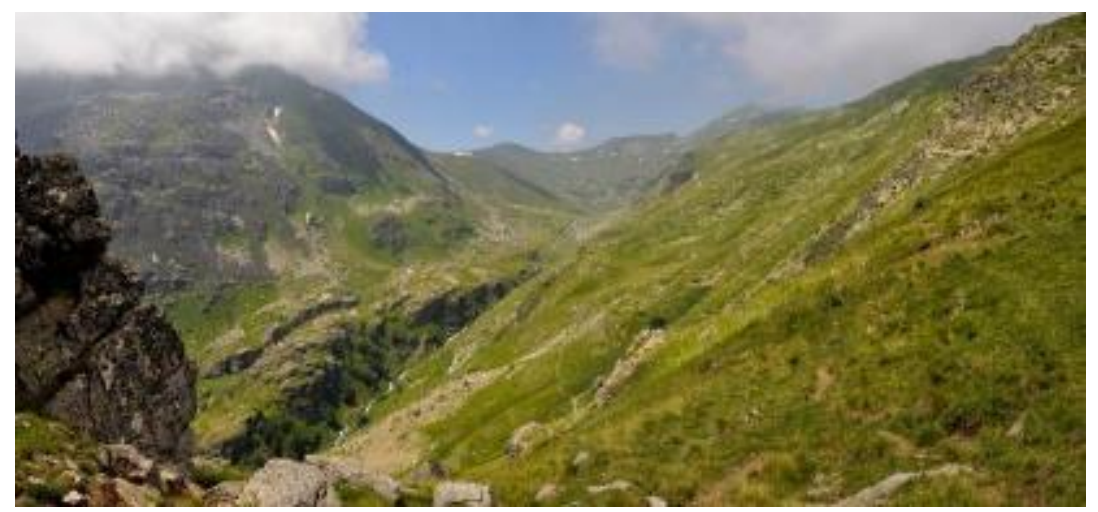

VQI: 0.67 (13); 0.73 (13)

VQI 2km²: 0.71 | (T) 0.83 (BS) 0.50 (GS) 0.77 (H/C) 0.65 


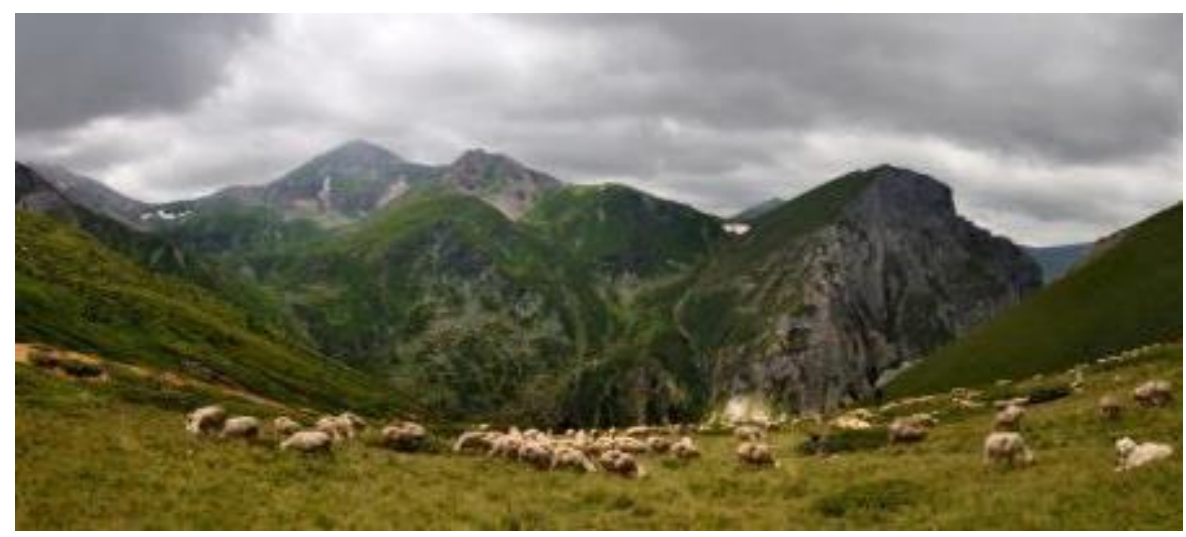

VQI: 0.70 (11); 0.64 (15); 0.72 (10); 0.69 (13)

VQI 2km²: 0.74 | (T) 0.92 (BS) 0.36 (GS) 0.83 (H/C) 0.74

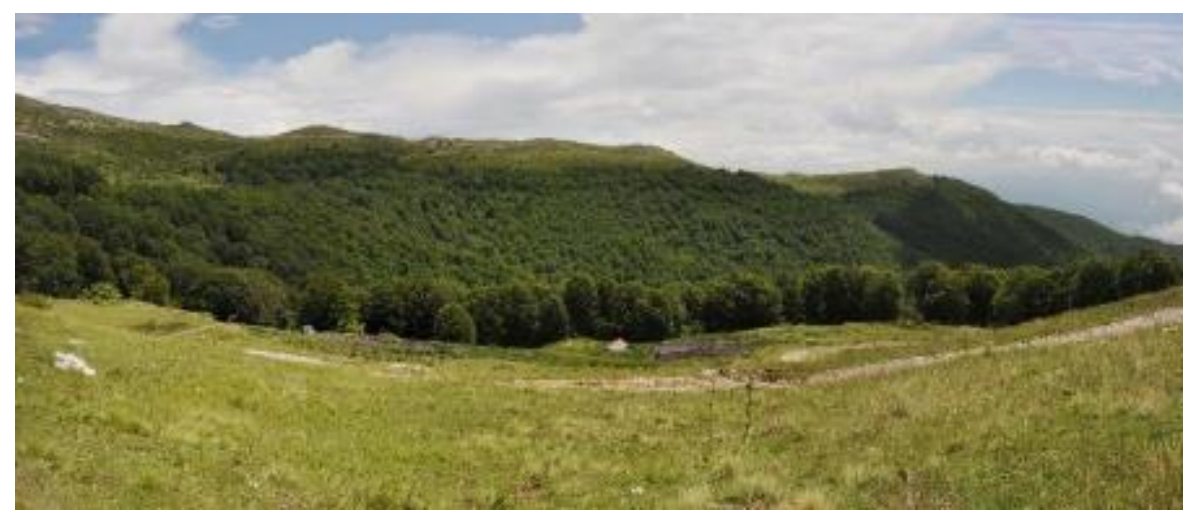

VQI: $0.59(8) ; 0.62(10)$

VQI 2km²: 0.67 | (T) 0.83 (BS) 0.36 (GS) 0.69 (H/C) 0.74

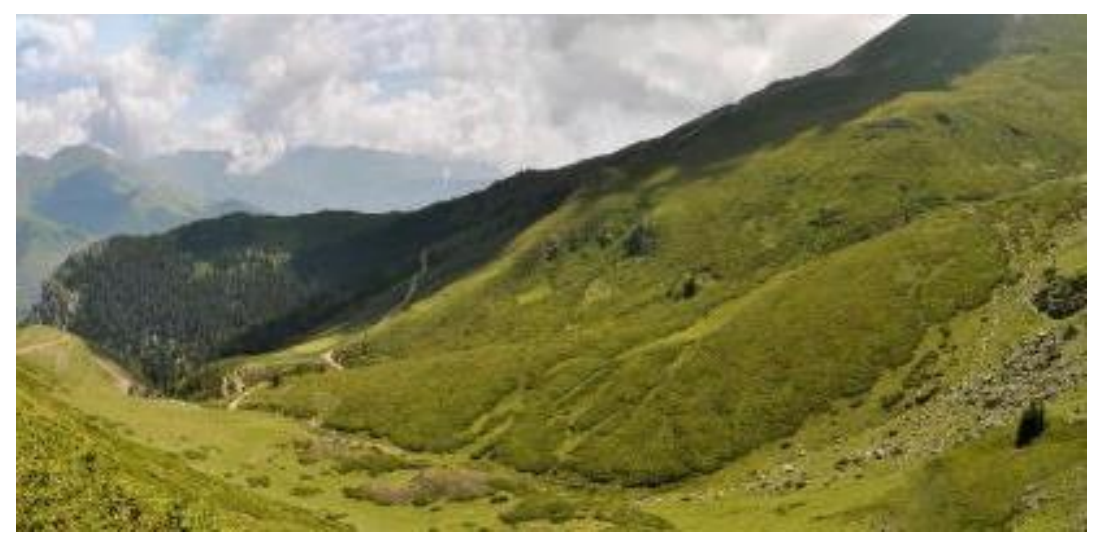

VQI: 0.73 (7); 0.67 (15)

VQI 2km²: 0.69 | (T) 0.83 (BS) 0.43 (GS) 0.71 (H/C) 0.71

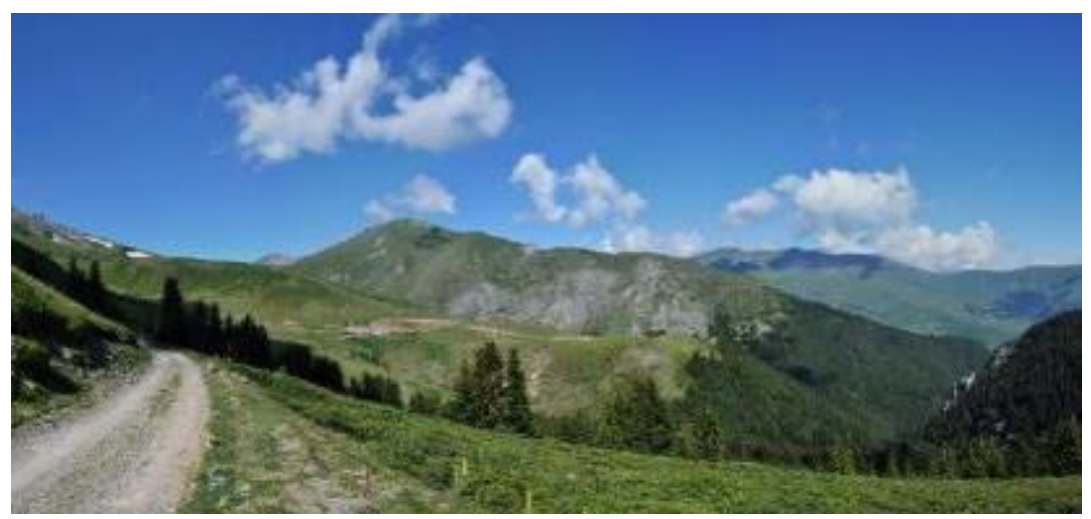

VQI: 0.71 (10); 0.70 (10); 0.70 (10)

VQI 2km²: 0.69 | (T) 0.83 (BS) 0.43 (GS) 0.71 (H/C) 0.71 


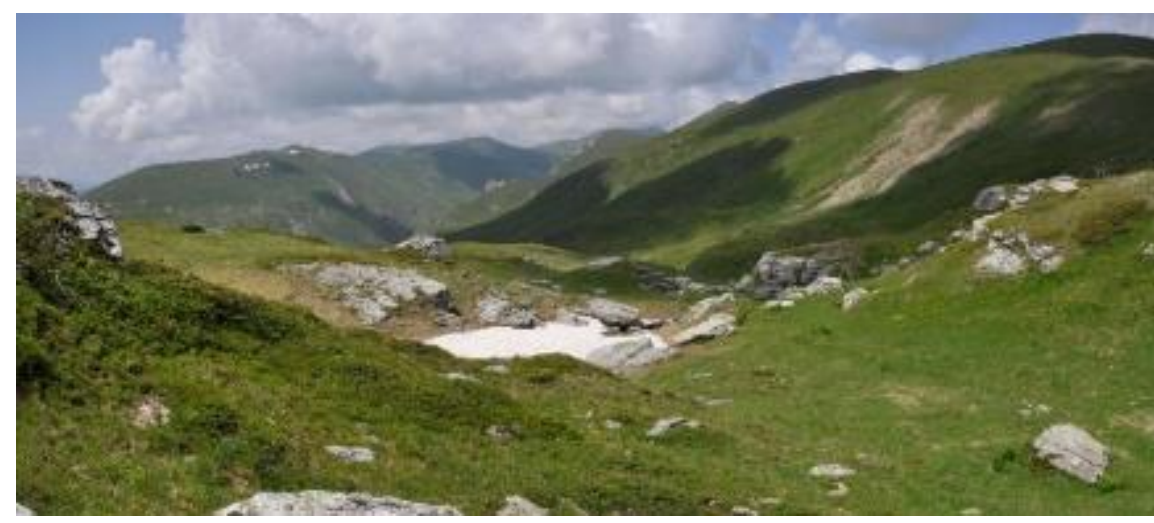

VQI: 0.64 (11); 0.64 (11); 0.64 (11)

VQI 2km²: 0.67 | (T) 0.75 (BS) 0.43 (GS) 0.77 (H/C) 0.65

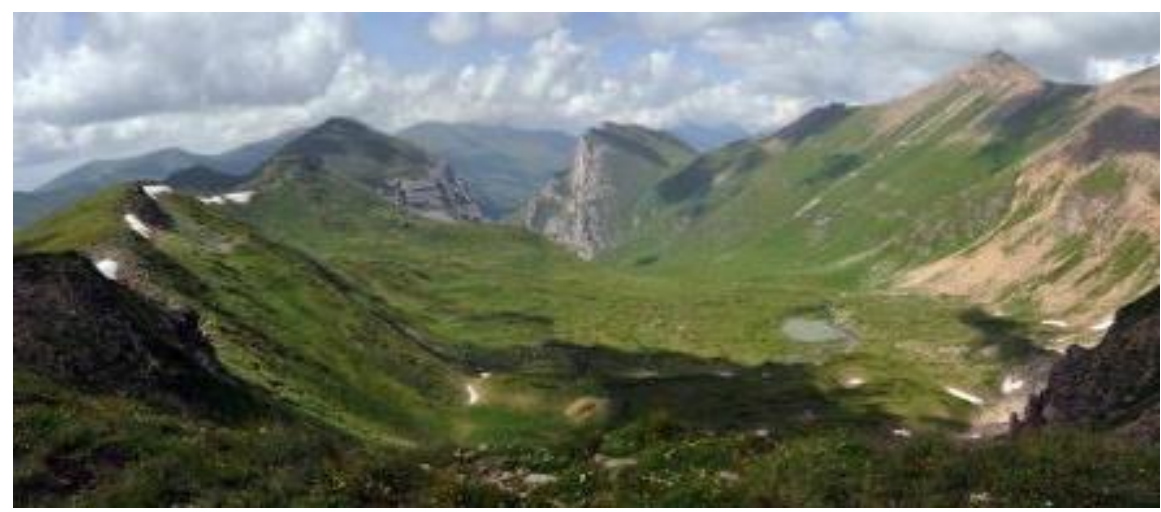

VQI: 0.78 (10); 0.68 (8); 0.73 (9)

VQI 2km²: 0.71 | (T) 0.92 (BS) 0.50 (GS) 0.63 (H/C) 0.74

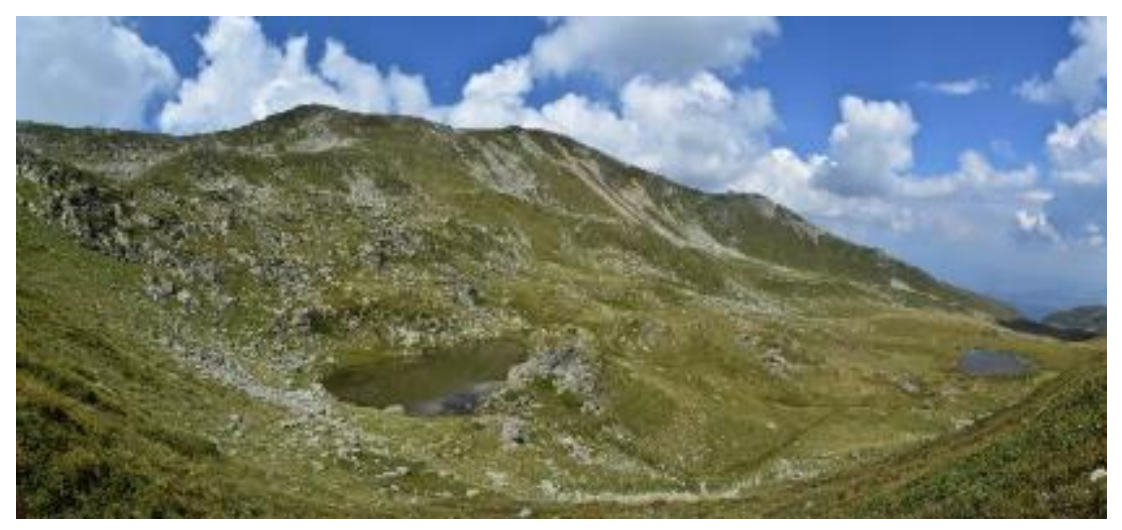

VQI: 0.68 (14); 0.68 (15)

VQI 2km²: 0.72 | (T) 0.83 (BS) 0.43 (GS) 0.86 (H/C) 0.65

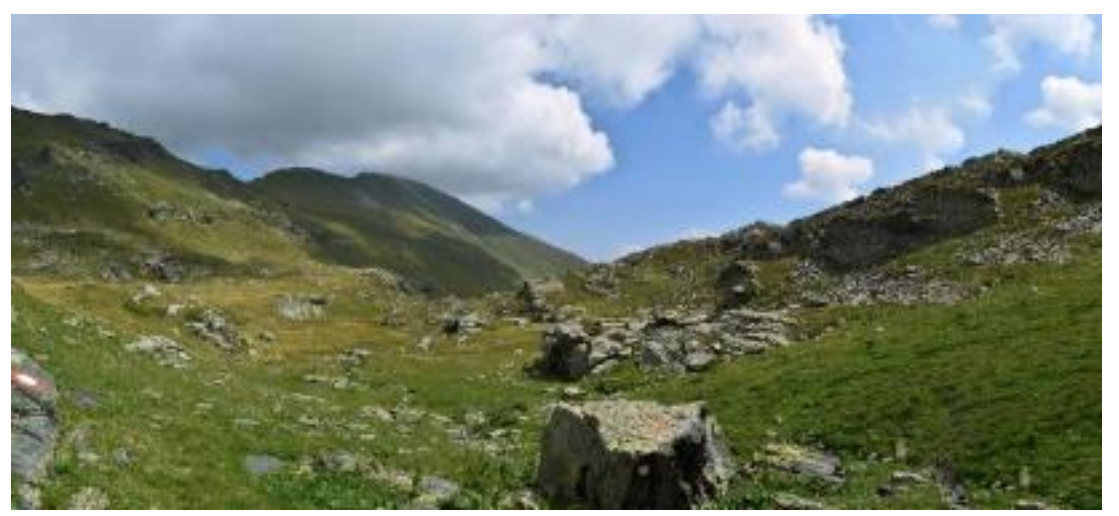

VQI: 0.54 (12); 0.56 (7)

VQI 2km²: 0.75 | (T) 0.83 (BS) 0.57 (GS) 0.77 (H/C) 0.79 


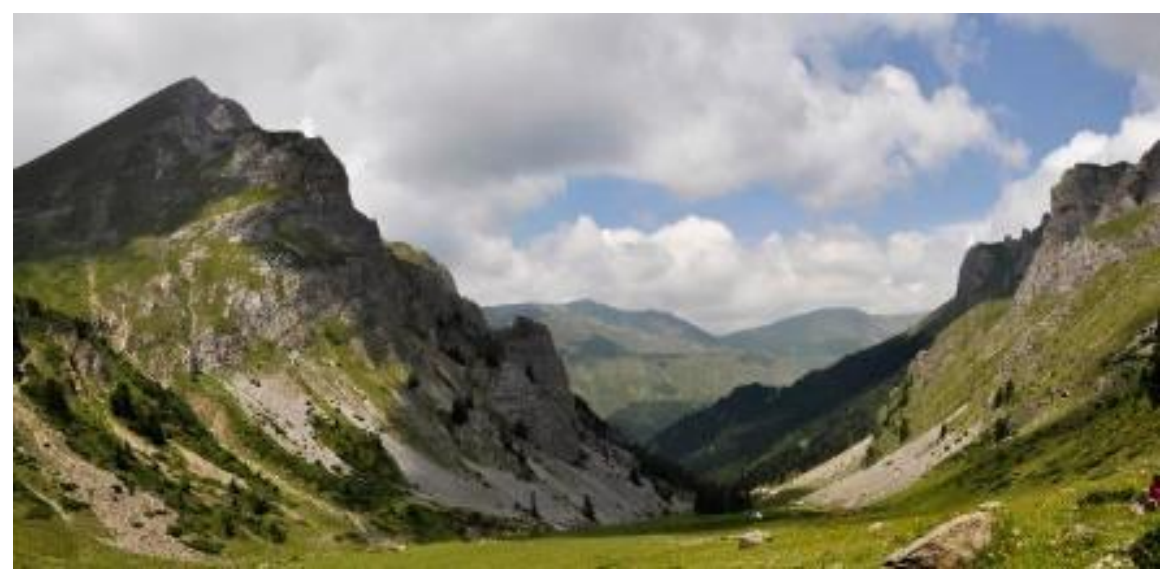

VQI: 0.66 (10); 0.68 (13); 0.60 (10)

VQI 2km²: 0.73 | (T) 0.92 (BS) 0.57 (GS) 0.71 (H/C) 0.65

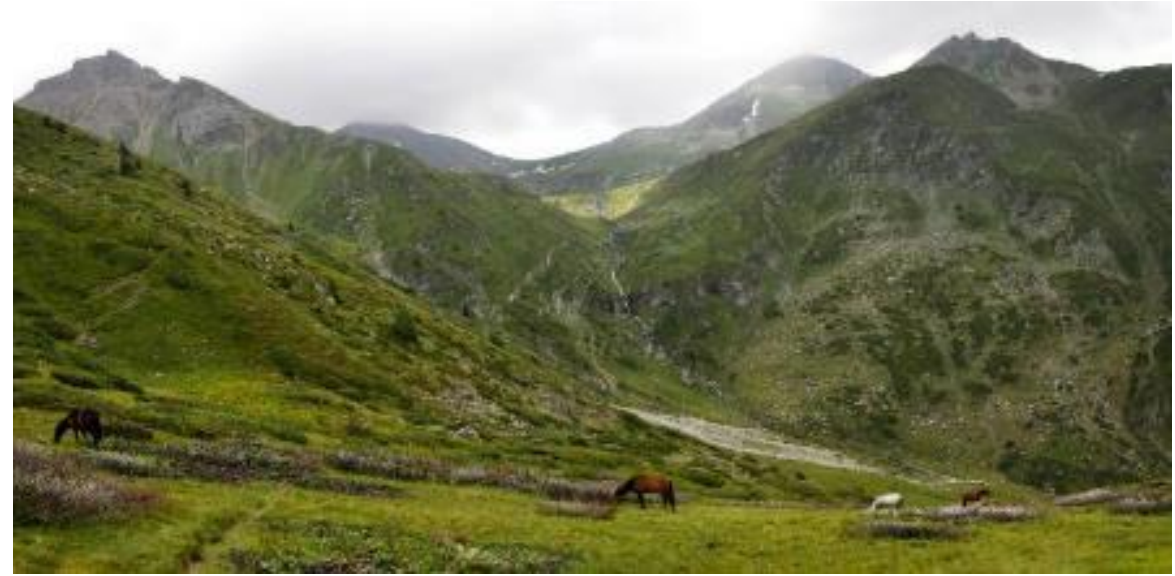

VQI: 0.69 (10); 0.69 (10)

VQI 2km²: 0.74 | (T) 0.92 (BS) 0.36 (GS) 0.83 (H/C) 0.74

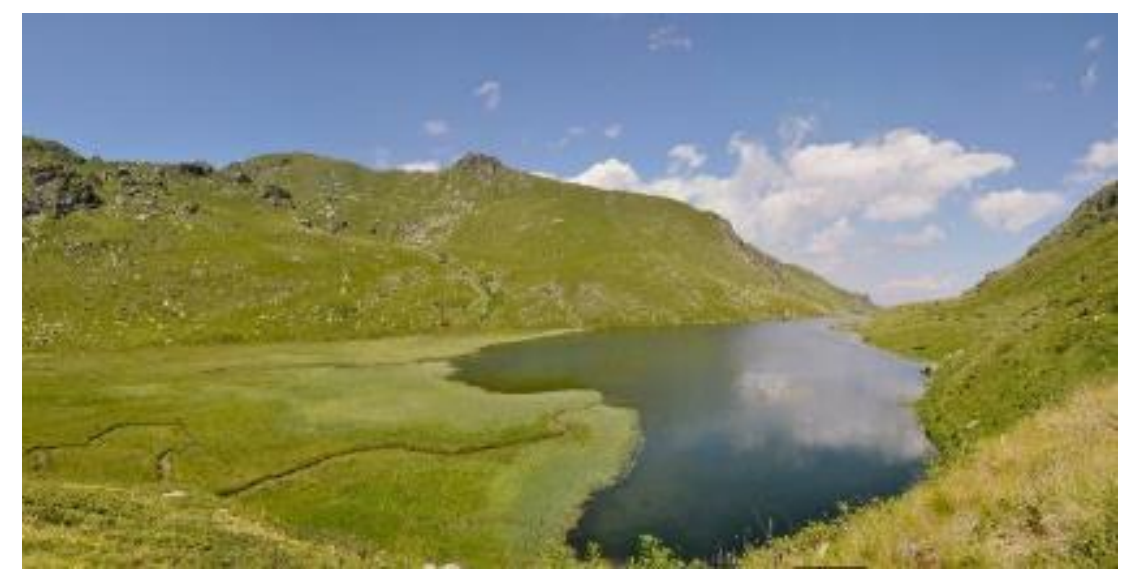

VQI: 0.73 (11); 0.71 (14)

VQI 2km²: 0.76 | (T) 0.75 (BS) 0.71 (GS) 0.77 (H/C) 0.79

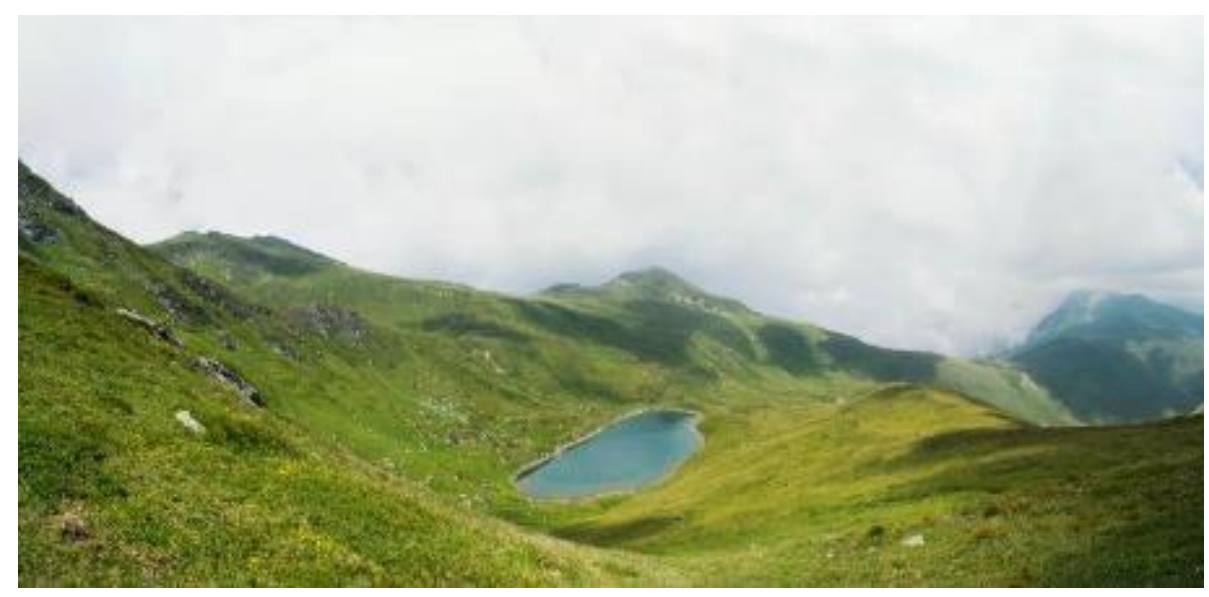

VQI: 0.60 (14); 0.55 (10)

VQI 2km²: 0.75 | (T) 0.75 (BS) 0.86 (GS) 0.77 (H/C) 0.59 


\section{S5: Details of visual quality ratings of sites with highest VQI scores (VQI $\geq 0.60$ ) according to the GIS visual quality assessment applied on a scale of $2 \mathrm{~km}^{2}$}

Site coordinates are provided in WGS 84/UTM zone 34N. The dominant landscape type within assessed $2 \mathrm{~km}^{2}$ survey square is marked in bold.

\begin{tabular}{|c|c|c|c|c|c|c|c|c|}
\hline Label & $x$ & $Y$ & $\begin{array}{l}\text { Physical } \\
\text { theme }\end{array}$ & $\begin{array}{l}\text { Blue } \\
\text { space }\end{array}$ & $\begin{array}{l}\text { Green } \\
\text { space }\end{array}$ & $\begin{array}{l}\text { Human/ } \\
\text { Cultural }\end{array}$ & VQI & Landscape \\
\hline DM8351 & 7483000 & 4651000 & 1 & 0.5 & 0.71 & 0.79 & 0.77 & $\begin{array}{l}\text { Spruce-fir forest landscape; Landscape of limestone } \\
\text { rocky ground; Mountain grassland landscape on } \\
\text { limestone ground }\end{array}$ \\
\hline DM8345 & 7483000 & 4645000 & 0.75 & 0.71 & 0.77 & 0.79 & 0.76 & $\begin{array}{l}\text { Mountain grassland landscape on silicate ground; } \\
\text { Landscape of silicate rocky ground }\end{array}$ \\
\hline DM8143 & 7481000 & 4643000 & 0.75 & 0.64 & 0.89 & 0.65 & 0.75 & $\begin{array}{l}\text { Mountain grassland landscape on silicate ground; } \\
\text { Landscape of silicate rocky ground }\end{array}$ \\
\hline DM8343 & 7483000 & 4643000 & 0.83 & 0.57 & 0.77 & 0.79 & 0.75 & $\begin{array}{l}\text { Mountain grassland landscape on silicate ground; } \\
\text { Landscape of silicate rocky ground; Mountain grassland } \\
\text { landscape on silicate ground }\end{array}$ \\
\hline DM8359 & 7483000 & 4659000 & 0.75 & 0.86 & 0.77 & 0.59 & 0.75 & Mountain grassland landscape on silicate ground \\
\hline EM0771 & 7507000 & 4671000 & 0.75 & 0.71 & 0.86 & 0.65 & 0.75 & Mountain grassland landscape on silicate ground \\
\hline DM8157 & 7481000 & 4657000 & 0.75 & 0.79 & 0.77 & 0.65 & 0.74 & Mountain grassland landscape on silicate ground \\
\hline DM8553 & 7485000 & 4653000 & 0.92 & 0.36 & 0.83 & 0.74 & 0.74 & $\begin{array}{l}\text { Spruce-fir forest landscape; Landscape of limestone } \\
\text { rocky ground; Mountain grassland landscape on } \\
\text { limestone ground }\end{array}$ \\
\hline DM8551 & 7485000 & 4651000 & 0.92 & 0.57 & 0.71 & 0.65 & 0.73 & $\begin{array}{l}\text { Landscape of limestone rocky ground; Mountain } \\
\text { grassland landscape on limestone ground }\end{array}$ \\
\hline DM9363 & 7493000 & 4663000 & 0.83 & 0.57 & 0.8 & 0.65 & 0.73 & $\begin{array}{l}\text { Mountain rural landscape; Mountain grassland } \\
\text { landscape on silicate ground }\end{array}$ \\
\hline DM8353 & 7483000 & 4653000 & 0.92 & 0.5 & 0.71 & 0.65 & 0.72 & $\begin{array}{l}\text { Spruce-fir forest landscape; Landscape of limestone } \\
\text { rocky ground; Mountain grassland landscape on } \\
\text { limestone ground }\end{array}$ \\
\hline EM0167 & 7501000 & 4667000 & 0.83 & 0.43 & 0.86 & 0.65 & 0.72 & Mountain grassland landscape on silicate ground \\
\hline EM0367 & 7503000 & 4667000 & 0.83 & 0.36 & 0.8 & 0.79 & 0.72 & $\begin{array}{l}\text { Mesophillous broadleaf forest landscape; Mountain } \\
\text { grassland landscape on silicate ground }\end{array}$ \\
\hline DM7131 & 7471000 & 4631000 & 0.83 & 0.36 & 0.86 & 0.65 & 0.71 & $\begin{array}{l}\text { Mountain grassland landscape on silicate ground; } \\
\text { Spruce-fir forest landscape }\end{array}$ \\
\hline DM8145 & 7481000 & 4645000 & 0.75 & 0.64 & 0.77 & 0.65 & 0.71 & $\begin{array}{l}\text { Mountain grassland landscape on silicate ground; } \\
\text { Mountain grassland landscape on limestone ground; } \\
\text { Landscape of silicate rocky ground }\end{array}$ \\
\hline DM8349 & 7483000 & 4649000 & 0.92 & 0.5 & 0.63 & 0.74 & 0.71 & $\begin{array}{l}\text { Mountain grassland landscape on limestone ground; } \\
\text { Landscape of limestone rocky ground; Mountain } \\
\text { grassland landscape on silicate ground }\end{array}$ \\
\hline DM8545 & 7485000 & 4645000 & 0.83 & 0.5 & 0.77 & 0.65 & 0.71 & $\begin{array}{l}\text { Landscape of silicate rocky ground; Mountain grassland } \\
\text { landscape on silicate ground; Mountain grassland } \\
\text { landscape on silicate ground; Mountain rural landscape }\end{array}$ \\
\hline DM7529 & 7475000 & 4629000 & 0.83 & 0.43 & 0.77 & 0.65 & 0.7 & $\begin{array}{l}\text { Spruce-fir forest landscape; Mountain grassland } \\
\text { landscape on silicate ground; Mountain rural landscape }\end{array}$ \\
\hline DM7533 & 7475000 & 4633000 & 0.83 & 0.43 & 0.77 & 0.65 & 0.7 & Mountain grassland landscape on silicate ground \\
\hline DM8153 & 7481000 & 4653000 & 0.92 & 0.43 & 0.71 & 0.65 & 0.7 & $\begin{array}{l}\text { Mountain grassland landscape on limestone ground; } \\
\text { Spruce-fir forest landscape; Landscape of limestone } \\
\text { rocky ground; Mountain grassland landscape on silicate } \\
\text { ground }\end{array}$ \\
\hline DM8961 & 7489000 & 4661000 & 0.92 & 0.43 & 0.69 & 0.65 & 0.7 & $\begin{array}{l}\text { Mountain rural landscape; Mountain grassland } \\
\text { landscape on silicate ground }\end{array}$ \\
\hline DM9565 & 7495000 & 4665000 & 0.75 & 0.43 & 0.86 & 0.65 & 0.7 & Mountain grassland landscape on silicate ground \\
\hline
\end{tabular}




\begin{tabular}{|c|c|c|c|c|c|c|c|c|}
\hline DM9967 & 7499000 & 4667000 & 0.92 & 0.43 & 0.71 & 0.65 & 0.7 & Mountain grassland landscape on silicate ground \\
\hline DM7531 & 7475000 & 4631000 & 0.83 & 0.21 & 0.89 & 0.65 & 0.69 & $\begin{array}{l}\text { Spruce-fir forest landscape; Mountain grassland } \\
\text { landscape on silicate ground }\end{array}$ \\
\hline DM7735 & 7477000 & 4635000 & 0.75 & 0.5 & 0.77 & 0.65 & 0.69 & Mountain grassland landscape on silicate ground \\
\hline DM7939 & 7479000 & 4639000 & 0.75 & 0.5 & 0.77 & 0.65 & 0.69 & Landscape of silicate rocky ground \\
\hline DM8753 & 7487000 & 4653000 & 0.83 & 0.43 & 0.71 & 0.71 & 0.69 & $\begin{array}{l}\text { Spruce-fir forest landscape; Landscape of limestone } \\
\text { rocky ground; Mountain grassland landscape on } \\
\text { limestone ground }\end{array}$ \\
\hline DM9365 & 7493000 & 4665000 & 0.83 & 0.36 & 0.8 & 0.65 & 0.69 & Mountain grassland landscape on silicate ground \\
\hline EM0973 & 7509000 & 4673000 & 0.92 & 0.21 & 0.8 & 0.65 & 0.69 & $\begin{array}{l}\text { Mesophillous broadleaf forest landscape; Mountain } \\
\text { grassland landscape on silicate ground; Landscape of } \\
\text { limestone rocky ground }\end{array}$ \\
\hline DM8149 & 7481000 & 4649000 & 0.83 & 0.36 & 0.77 & 0.65 & 0.68 & $\begin{array}{l}\text { Landscape of limestone rocky ground; Mountain } \\
\text { grassland landscape on limestone ground }\end{array}$ \\
\hline DM8357 & 7483000 & 4657000 & 0.75 & 0.36 & 0.86 & 0.65 & 0.68 & $\begin{array}{l}\text { Mountain rural landscape; Mountain grassland } \\
\text { landscape on silicate ground }\end{array}$ \\
\hline DM8761 & 7487000 & 4661000 & 0.92 & 0.21 & 0.77 & 0.65 & 0.68 & Mountain grassland landscape on silicate ground \\
\hline DM7951 & 7479000 & 4651000 & 0.75 & 0.21 & 0.91 & 0.65 & 0.67 & Mountain grassland landscape on limestone ground \\
\hline DM7955 & 7479000 & 4655000 & 0.58 & 0.43 & 0.89 & 0.74 & 0.67 & Mountain grassland landscape on silicate ground \\
\hline DM8147 & 7481000 & 4647000 & 0.75 & 0.43 & 0.77 & 0.65 & 0.67 & $\begin{array}{l}\text { Mountain grassland landscape on limestone ground; } \\
\text { Mountain grassland landscape on silicate ground }\end{array}$ \\
\hline EM1171 & 7511000 & 4671000 & 0.83 & 0.36 & 0.69 & 0.74 & 0.67 & $\begin{array}{l}\text { Mesophillous broadleaf forest landscape; Mountain } \\
\text { grassland landscape on limestone ground; Landscape of } \\
\text { limestone rocky ground; Mountain grassland landscape } \\
\text { on silicate ground }\end{array}$ \\
\hline DM7535 & 7475000 & 4635000 & 0.75 & 0.29 & 0.8 & 0.65 & 0.65 & Mountain grassland landscape on silicate ground \\
\hline DM8139 & 7481000 & 4639000 & 0.83 & 0.21 & 0.74 & 0.65 & 0.65 & $\begin{array}{l}\text { Landscape of silicate rocky ground; Mountain grassland } \\
\text { landscape on silicate ground; Mesophillous broadleaf } \\
\text { forest landscape }\end{array}$ \\
\hline DM8751 & 7487000 & 4651000 & 0.92 & 0.29 & 0.66 & 0.59 & 0.65 & $\begin{array}{l}\text { Mountain grassland landscape on limestone ground; } \\
\text { Landscape of limestone rocky ground }\end{array}$ \\
\hline DM9765 & 7497000 & 4665000 & 0.83 & 0.14 & 0.8 & 0.65 & 0.65 & Mountain grassland landscape on silicate ground \\
\hline EM0569 & 7505000 & 4669000 & 0.67 & 0.29 & 0.83 & 0.74 & 0.65 & $\begin{array}{l}\text { Mesophillous broadleaf forest landscape; Mountain } \\
\text { grassland landscape on silicate ground }\end{array}$ \\
\hline EM0769 & 7507000 & 4669000 & 0.58 & 0.57 & 0.69 & 0.79 & 0.65 & $\begin{array}{l}\text { Mesophillous broadleaf forest landscape; Mountain } \\
\text { grassland landscape on silicate ground }\end{array}$ \\
\hline DM7125 & 7471000 & 4625000 & 0.75 & 0.21 & 0.71 & 0.76 & 0.64 & Spruce-fir forest landscape; Mountain rural landscape \\
\hline DM7929 & 7479000 & 4629000 & 0.42 & 0.57 & 0.86 & 0.71 & 0.64 & $\begin{array}{l}\text { Mesophillous broadleaf forest landscape; Mountain } \\
\text { grassland landscape on silicate ground }\end{array}$ \\
\hline DM8151 & 7481000 & 4651000 & 0.92 & 0.21 & 0.66 & 0.65 & 0.64 & $\begin{array}{l}\text { Mountain grassland landscape on limestone ground; } \\
\text { Landscape of limestone rocky ground; Spruce-fir forest } \\
\text { landscape }\end{array}$ \\
\hline DM8155 & 7481000 & 4655000 & 0.75 & 0.29 & 0.77 & 0.65 & 0.64 & $\begin{array}{l}\text { Mountain grassland landscape on silicate ground; } \\
\text { Mountain grassland landscape on limestone ground }\end{array}$ \\
\hline DM9361 & 7493000 & 4661000 & 0.58 & 0.43 & 0.86 & 0.59 & 0.64 & $\begin{array}{l}\text { Mountain rural landscape; Mountain grassland } \\
\text { landscape on silicate ground }\end{array}$ \\
\hline DM9965 & 7499000 & 4665000 & 0.75 & 0.29 & 0.77 & 0.65 & 0.64 & $\begin{array}{l}\text { Mesophillous broadleaf forest landscape; Mountain } \\
\text { grassland landscape on silicate ground }\end{array}$ \\
\hline EM0369 & 7503000 & 4669000 & 0.83 & 0.29 & 0.71 & 0.59 & 0.64 & Mountain grassland landscape on silicate ground \\
\hline EM0773 & 7507000 & 4673000 & 0.83 & 0.21 & 0.71 & 0.65 & 0.64 & Mountain grassland landscape on silicate ground \\
\hline EM0971 & 7509000 & 4671000 & 0.50 & 0.36 & 0.86 & 0.79 & 0.64 & $\begin{array}{l}\text { Mesophillous broadleaf forest landscape; Mountain } \\
\text { grassland landscape on silicate ground }\end{array}$ \\
\hline DM7331 & 7473000 & 4631000 & 0.83 & 0.36 & 0.74 & 0.44 & 0.63 & $\begin{array}{l}\text { Spruce-fir forest landscape; Mountain grassland } \\
\text { landscape on silicate ground }\end{array}$ \\
\hline
\end{tabular}




\begin{tabular}{|c|c|c|c|c|c|c|c|c|}
\hline DM7937 & 7479000 & 4637000 & 0.83 & 0.29 & 0.63 & 0.65 & 0.63 & $\begin{array}{l}\text { Mountain grassland landscape on silicate ground; } \\
\text { Landscape of silicate rocky ground }\end{array}$ \\
\hline DM8141 & 7481000 & 4641000 & 0.83 & 0.29 & 0.63 & 0.65 & 0.63 & $\begin{array}{l}\text { Mountain grassland landscape on silicate ground; } \\
\text { Landscape of silicate rocky ground }\end{array}$ \\
\hline DM8341 & 7483000 & 4641000 & 0.83 & 0.21 & 0.63 & 0.74 & 0.63 & $\begin{array}{l}\text { Mountain grassland landscape on silicate ground; } \\
\text { Landscape of silicate rocky ground }\end{array}$ \\
\hline DM8347 & 7483000 & 4647000 & 0.75 & 0.36 & 0.69 & 0.65 & 0.63 & $\begin{array}{l}\text { Mountain grassland landscape on silicate ground; } \\
\text { Mountain grassland landscape on limestone ground }\end{array}$ \\
\hline DM8549 & 7485000 & 4649000 & 0.83 & 0.29 & 0.63 & 0.65 & 0.63 & $\begin{array}{l}\text { Mountain grassland landscape on limestone ground; } \\
\text { Landscape of limestone rocky ground; Mountain } \\
\text { grassland landscape on silicate ground }\end{array}$ \\
\hline DM8755 & 7487000 & 4655000 & 0.83 & 0.29 & 0.71 & 0.56 & 0.63 & $\begin{array}{l}\text { Mountain rural landscape; Spruce-fir forest landscape; } \\
\text { Mountain grassland landscape on limestone ground }\end{array}$ \\
\hline DM9349 & 7493000 & 4649000 & 0.67 & 0.50 & 0.71 & 0.59 & 0.63 & $\begin{array}{l}\text { Mountain grassland landscape on silicate ground; } \\
\text { Mountain rural landscape; Hilly rural landscape }\end{array}$ \\
\hline EM0969 & 7509000 & 4669000 & 0.67 & 0.43 & 0.74 & 0.59 & 0.63 & $\begin{array}{l}\text { Mesophillous broadleaf forest landscape; Mountain } \\
\text { grassland landscape on silicate ground }\end{array}$ \\
\hline DM7935 & 7479000 & 4635000 & 0.58 & 0.43 & 0.77 & 0.65 & 0.62 & Mountain grassland landscape on silicate ground \\
\hline DM7953 & 7479000 & 4653000 & 0.67 & 0.29 & 0.77 & 0.65 & 0.62 & $\begin{array}{l}\text { Mountain grassland landscape on silicate ground; } \\
\text { Mountain grassland landscape on limestone ground }\end{array}$ \\
\hline DM8951 & 7489000 & 4651000 & 0.67 & 0.43 & 0.74 & 0.56 & 0.62 & $\begin{array}{l}\text { Mountain rural landscape; Mountain grassland } \\
\text { landscape on limestone ground }\end{array}$ \\
\hline DM7729 & 7477000 & 4629000 & 0.42 & 0.64 & 0.77 & 0.65 & 0.61 & Mountain grassland landscape on silicate ground \\
\hline DM8135 & 7481000 & 4635000 & 0.58 & 0.43 & 0.63 & 0.79 & 0.61 & $\begin{array}{l}\text { Mountain grassland landscape on silicate ground; } \\
\text { Mesophillous broadleaf forest landscape }\end{array}$ \\
\hline DM8559 & 7485000 & 4659000 & 0.75 & 0.29 & 0.71 & 0.59 & 0.61 & $\begin{array}{l}\text { Mountain rural landscape; Mountain grassland } \\
\text { landscape on silicate ground }\end{array}$ \\
\hline DM9161 & 7491000 & 4661000 & 0.83 & 0.14 & 0.69 & 0.65 & 0.61 & $\begin{array}{l}\text { Mountain rural landscape; Mountain grassland } \\
\text { landscape on silicate ground }\end{array}$ \\
\hline EM1173 & 7511000 & 4673000 & 0.92 & 0.07 & 0.69 & 0.56 & 0.61 & $\begin{array}{l}\text { Landscape of limestone rocky ground; Mountain } \\
\text { grassland landscape on limestone ground; Mountain } \\
\text { grassland landscape on silicate ground }\end{array}$ \\
\hline EM1371 & 7513000 & 4671000 & 0.75 & 0.21 & 0.77 & 0.56 & 0.61 & $\begin{array}{l}\text { Mesophillous broadleaf forest landscape; Mountain } \\
\text { grassland landscape on limestone ground; Hilly rural } \\
\text { landscape }\end{array}$ \\
\hline DM7129 & 7471000 & 4629000 & 0.75 & 0.29 & 0.77 & 0.44 & 0.60 & $\begin{array}{l}\text { Mesophillous broadleaf forest landscape; Spruce-fir } \\
\text { forest landscape; Mountain grassland landscape on } \\
\text { silicate ground }\end{array}$ \\
\hline DM7335 & 7473000 & 4635000 & 0.42 & 0.36 & 0.80 & 0.79 & 0.60 & Mountain grassland landscape on silicate ground \\
\hline DM7927 & 7479000 & 4627000 & 0.42 & 0.50 & 0.89 & 0.56 & 0.60 & Mountain grassland landscape on silicate ground \\
\hline DM8953 & 7489000 & 4653000 & 0.83 & 0.36 & 0.74 & 0.29 & 0.60 & $\begin{array}{l}\text { Spruce-fir forest landscape; Mountain grassland } \\
\text { landscape on limestone ground; Landscape of limestone } \\
\text { rocky ground; Mountain grassland landscape on silicate } \\
\text { ground }\end{array}$ \\
\hline EM0165 & 7501000 & 4665000 & 0.58 & 0.29 & 0.69 & 0.79 & 0.60 & $\begin{array}{l}\text { Mesophillous broadleaf forest landscape; Mountain } \\
\text { grassland landscape on silicate ground }\end{array}$ \\
\hline
\end{tabular}




\section{S6: Supplementary Material References}

Acar, C., Kurdoglu, B.C., Kurdoglu, O., and Acar, H., 2006. Public preferences for visual quality and management in the Kackar Mountains National Park (Turkey). International Journal of Sustainable Development \& World Ecology, 13 (6), 499-512.

Arias-García, J., Serrano-Montes, J.L., and Gómez-Zotano, J., 2016. Fauna in wetland landscapes: a perception approach. Landscape Research, 41 (5), 510-523.

Arriaza, M., Cañas-Ortega, J.F., Cañas-Madueño, J.A., and Ruiz-Aviles, P., 2004. Assessing the visual quality of rural landscapes. Landscape and Urban Planning, 69 (1), 115-125.

Barroso, F.L., Pinto-Correia, T., Ramos, I.L., Surová, D., and Menezes, H., 2012. Dealing with landscape fuzziness in user preference studies: Photo-based questionnaires in the Mediterranean context. Landscape and Urban Planning, 104 (3-4), 329-342.

Brush, R., Chenoweth, R.E., and Barman, T., 2000. Group differences in the enjoyability of driving through rural landscapes. Landscape and Urban Planning, 47 (1), 39-45.

Bulut, Z. and Karahan, F., 2010. Determining visual beauties of natural waterscapes: A case study for Tortum Valley (Erzurum/Turkey). Scientific Research and Essay, 5 (2), 170-182.

Devine-Wright, P. and Batel, S., 2013. Explaining public preferences for high voltage pylon designs: An empirical study of perceived fit in a rural landscape. Land Use Policy, 31, 640-649.

Díaz, P., Ruiz-Labourdette, D., Rodríguez Darias, A., Santana, A., Schmitz, M.F., and Pineda, F.D., 2013. Local population and visitors: perceptions and preferences of landscape in a touristic destination. In: F.D. Pineda, ed. WIT Transactions on State of the Art in Science and Engineering. WIT Press, 75-83.

Díaz, S., Pascual, U., Stenseke, M., Martín-López, B., Watson, R.T., Molnár, Z., Hill, R., Chan, K.M.A., Baste, I.A., Brauman, K.A., Polasky, S., Church, A., Lonsdale, M., Larigauderie, A., Leadley, P.W., van Oudenhoven, A.P.E., van der Plaat, F., Schröte, M., Lavorel, S., Aumeeruddy-Thomas, ildiz, Bukvareva, E., Davies, K., Demissew, S., Erpul, G., Failler, P., Guerra, C.A., Hewitt, C.L., Keune, H., Lindley, S., and Shirayama, Y., 2018. Assessing nature's contributions to people. Recognizing culture, and diverse sources of knowledge, can improve assessments. Science, 359 (6373), 270-272.

Dramstad, W.E., Tveit, M.S., Fjellstad, W.J., and Fry, G.L.A., 2006. Relationships between visual landscape preferences and map-based indicators of landscape structure. Landscape and Urban Planning, 78 (4), 465-474.

Ferrari, C., Pezzi, G., Diani, L., and Corazza, M., 2008. Evaluating landscape quality with vegetation naturalness maps: an index and some inferences. Applied Vegetation Science, 11 (2), 243-250.

Frank, S., Fürst, C., Koschke, L., Witt, A., and Makeschin, F., 2013. Assessment of landscape aestheticsValidation of a landscape metrics-based assessment by visual estimation of the scenic beauty. Ecological Indicators, 32, 222-231.

Fry, G., Tveit, M.S., Ode, å., and Velarde, M.D., 2009. The ecology of visual landscapes: Exploring the conceptual common ground of visual and ecological landscape indicators. Ecological Indicators, 9 (5), 933-947. 
Garré, S., Meeus, S., and Gulinck, H., 2009. The dual role of roads in the visual landscape: A case-study in the area around Mechelen (Belgium). Landscape and Urban Planning, 92 (2), 125-135.

Gobster, P.H., Nassauer, J.I., Daniel, T.C., and Fry, G., 2007. The shared landscape: what does aesthetics have to do with ecology? Landscape Ecology, 22 (7), 959-972.

Gulinck, H., Múgica, M., de Lucio, J.V., and Atauri, J.A., 2001. A framework for comparative landscape analysis and evaluation based on land cover data, with an application in the Madrid region (Spain). Landscape and Urban Planning, 55 (4), 257-270.

Häfner, K., Zasada, I., van Zanten, B.T., Ungaro, F., Koetse, M., and Piorr, A., 2018. Assessing landscape preferences: a visual choice experiment in the agricultural region of Märkische Schweiz, Germany. Landscape Research, 43 (6), 846-861.

Hassan, R.M., Scholes, R.J., and Ash, N., eds., 2005. Ecosystems and human well-being: current state and trends. Washington, DC: Island Press.

Howley, P., 2011. Landscape aesthetics: Assessing the general publics' preferences towards rural landscapes. Ecological Economics, 72, 161-169.

Howley, P., Donoghue, C.O., and Hynes, S., 2012. Exploring public preferences for traditional farming landscapes. Landscape and Urban Planning, 104 (1), 66-74.

Hudson, B.J., 2000. The Experience of Waterfalls. Australian Geographical Studies, 38 (1), 71-84.

Hudson, B.J., 2013. Waterfalls, science and aesthetics. Journal of Cultural Geography, 30 (3), 356-379.

van der Jagt, A.P.N., Craig, T., Anable, J., Brewer, M.J., and Pearson, D.G., 2014. Unearthing the picturesque: The validity of the preference matrix as a measure of landscape aesthetics. Landscape and Urban Planning, $124,1-13$.

Jovanovska, D., 2019. Use of Sentinel-2 for land cover classification on Shar Planina, North Macedonia. Mendeley Data, v1.

Kaplan, A., Taşkın, T., and Önenç, A., 2006. Assessing the Visual Quality of Rural and Urban-fringed Landscapes surrounding Livestock Farms. Biosystems Engineering, 95 (3), 437-448.

Kurdoglu, O., 2015. Effect of traditional highland settlement texture on visual carrying capacity: Kackar Mountains National Park case. Journal of Environmental Protection and Ecology, 16 (2), 771-782.

Lindemann-Matthies, P., Briegel, R., Schüpbach, B., and Junge, X., 2010. Aesthetic preference for a Swiss alpine landscape: The impact of different agricultural land-use with different biodiversity. Landscape and Urban Planning, 98 (2), 99-109.

Melovski, L., Hristovski, S., Melovski, D., Kolchakovski, D., Velevski, M., Angelova, N., Levkov, Z., and Karadelev, M., 2010. Natural Values of Shar Planina Mt. Skopje: Macedonian Ecological Society.

Melovski, L., Jovanovska, D., and Hristovski, S., 2019. Landscape diversity in North Macedonia. Macedonian Journal of Ecology and Environment, 21 (1-2), 35-64. 
Molnarova, K., Sklenicka, P., Stiborek, J., Svobodova, K., Salek, M., and Brabec, E., 2012. Visual preferences for wind turbines: Location, numbers and respondent characteristics. Applied Energy, 92, 269-278.

Nepal, S.K. and Chipeniuk, R., 2005. Mountain Tourism: Toward a Conceptual Framework. Tourism Geographies, 7 (3), 313-333.

Norton, L.R., Inwood, H., Crowe, A., and Baker, A., 2012. Trialling a method to quantify the 'cultural services' of the English landscape using Countryside Survey data. Land Use Policy, 29 (2), 449-455.

Ode, Å., Fry, G., Tveit, M.S., Messager, P., and Miller, D., 2009. Indicators of perceived naturalness as drivers of landscape preference. Journal of Environmental Management, 90 (1), 375-383.

Ode, Å., Hagerhall, C.M., and Sang, N., 2010. Analysing Visual Landscape Complexity: Theory and Application. Landscape Research, 35 (1), 111-131.

Ode, Å. and Miller, D., 2011. Analysing the relationship between indicators of landscape complexity and preference. Environment and Planning B: Planning and Design, 38 (1), 24-40.

Ode, Å., Tveit, M.S., and Fry, G., 2008. Capturing Landscape Visual Character Using Indicators: Touching Base with Landscape Aesthetic Theory. Landscape Research, 33 (1), 89-117.

Otero Pastor, I., Casermeiro Martínez, M.A., Ezquerra Canalejoa, A., and Esparcia Mariño, P., 2007. Landscape evaluation: Comparison of evaluation methods in a region of Spain. Journal of Environmental Management, 85 (1), 204-214.

Petrova, E.G., Mironov, Y.V., Aoki, Y., Matsushima, H., Ebine, S., Furuya, K., Petrova, A., Takayama, N., and Ueda, $H ., 2015$. Comparing the visual perception and aesthetic evaluation of natural landscapes in Russia and Japan: cultural and environmental factors. Progress in Earth and Planetary Science, 2 (1).

Purcell, A.T. and Lamb, R.J., 1998. Preference and naturalness: An ecological approach. Landscape and Urban Planning, 42 (1), 57-66.

Riley, S.J., DeGloria, S.D., and Elliot, R., 1999. A Terrain Ruggedness Index that Quantifies Topographic Heterogeneity. Intermountain Journal of Sciences, 5 (1-4), 23-27.

Rogge, E., Nevens, F., and Gulinck, H., 2007. Perception of rural landscapes in Flanders: Looking beyond aesthetics. Landscape and Urban Planning, 82 (4), 159-174.

Sang, N., Miller, D., and Ode, Å., 2008. Landscape Metrics and Visual Topology in the Analysis of Landscape Preference. Environment and Planning B: Planning and Design, 35 (3), 504-520.

Sari, D. and Acar, C., 2016. Visual Landscape Assessment of the Alpine Rocky Habitats: A Case Study of Hatila Valley National Park, Artvin, Turkey. In: R. Efe, I. Cürebal, A. Gad, and B. Tóth, eds. Environmental Sustainability and Landscape Management. Sofia: St. Kliment Ohridski University Press, 1-34.

Schirpke, U., Tasser, E., and Tappeiner, U., 2013. Predicting scenic beauty of mountain regions. Landscape and Urban Planning, 111, 1-12. 
Scott, A., 2002. Assessing Public Perception of Landscape: The LANDMAP experience. Landscape Research, 27 (3), 271-295.

Surová, D. and Pinto-correia, T., 2008. Landscape preferences in the cork oak Montado region of Alentejo, southern Portugal: Searching for valuable landscape characteristics for different user groups. Landscape Research, 33 (3), 311-330.

Swetnam, R.D., Harrison-Curran, S.K., and Smith, G.R., 2017. Quantifying visual landscape quality in rural Wales: A GIS-enabled method for extensive monitoring of a valued cultural ecosystem service. Ecosystem Services, 26, 451-464.

Swetnam, R.D. and Tweed, F.S., 2018. A tale of two landscapes: Transferring landscape quality metrics from Wales to Iceland. Land Use Policy, 76, 565-576.

Tratalos, J.A., Haines-Young, R., Potschin, M., Fish, R., and Church, A., 2016. Cultural ecosystem services in the UK: Lessons on designing indicators to inform management and policy. Ecological Indicators, 61, 63-73.

Tveit, M., Ode, А̊., and Fry, G., 2006. Key concepts in a framework for analysing visual landscape character. Landscape Research, 31 (3), 229-255.

Tveit, M.S., 2009. Indicators of visual scale as predictors of landscape preference; a comparison between groups. Journal of Environmental Management, 90 (9), 2882-2888.

Uzun, O. and Muuml, H., 2011. Visual landscape quality in landscape planning: Examples of Kars and Ardahan cities in Turkey. African Journal of Agricultural Research, 6 (6), 1627-1638.

Vizzari, M., 2011. Spatial modelling of potential landscape quality. Applied Geography, 31 (1), 108-118. 